Prepared for the U.S. Department of Energy under Contract DE-AC05-76RL01830

\title{
Preparation and Characterization of Uranium Oxides in Support of the K Basin Sludge Treatment Project
}

\author{
SI Sinkov \\ $\mathrm{CH}$ Delegard \\ AJ Schmidt
}

July 2008 


\title{
DISCLAIMER
}

This report was prepared as an account of work sponsored by an agency of the United States Government. Neither the United States Government nor any agency thereof, nor Battelle Memorial Institute, nor any of their employees, makes any warranty, express or implied, or assumes any legal liability or responsibility for the accuracy, completeness, or usefulness of any information, apparatus, product, or process disclosed, or represents that its use would not infringe privately owned rights. Reference herein to any specific commercial product, process, or service by trade name, trademark, manufacturer, or otherwise does not necessarily constitute or imply its endorsement, recommendation, or favoring by the United States Government or any agency thereof, or Battelle Memorial Institute. The views and opinions of authors expressed herein do not necessarily state or reflect those of the United States Government or any agency thereof.

\author{
PACIFIC NORTHWEST NATIONAL LABORATORY \\ operated by \\ BATTELLE \\ for the \\ UNITED STATES DEPARTMENT OF ENERGY \\ under Contract DE-AC05-76RL01830 \\ Printed in the United States of America \\ Available to DOE and DOE contractors from the \\ Office of Scientific and Technical Information, \\ P.O. Box 62, Oak Ridge, TN 37831-0062; \\ ph: (865) 576-8401 \\ fax: (865) 576-5728 \\ email: reports@adonis.osti.gov
}

\begin{abstract}
Available to the public from the National Technical Information Service,
U.S. Department of Commerce, 5285 Port Royal Rd., Springfield, VA 22161

ph: (800) 553-6847

fax: (703) 605-6900

email: orders@ntis.fedworld.gov

online ordering: http://www.ntis.gov/ordering.htm
\end{abstract}

This document was printed on recycled paper.

$(9 / 2003)$ 


\section{Preparation and Characterization of Uranium Oxides in Support of the K Basin Sludge Treatment Project}

SI Sinkov

$\mathrm{CH}$ Delegard

AJ Schmidt

July 2008

Prepared for the U.S. Department of Energy under Contract DE-AC05-76RL01830

Pacific Northwest National Laboratory

Richland, Washington 99352 


\section{Summary}

The objectives and key findings on the synthesis of metaschoepite from uraninite and the potential scavenging of hydrogen by metaschoepite in aqueous suspensions are presented for their application to production of simulant materials for $\mathrm{K}$ Basin sludge process testing. Uraninite and metaschoepite are the uranium phases most frequently observed in $\mathrm{K}$ Basin sludge. Uraninite arises from the oxidation of uranium metal by anoxic water and metaschoepite arises from oxidation of uraninite by atmospheric or radiolytic oxygen.

The key findings include development of a uranium oxide oxidation state characterization method, determination of the properties and reactivities of the uraninite, metaschoepite, and intermediate materials to dissolved oxygen and hydrogen gas, and the identification of a rapid alternative method to determine uranium metal concentrations in sludge.

In summary, the testing:

- Led to development of a rapid, accurate, and precise spectrophotometric means to measure uranium oxidation state in uranium oxide materials and slurries. This method can be applied to measure the distribution of oxidation states in uranium oxides in $\mathrm{K}$ Basin sludge.

- Showed that the uraninite produced by anoxic corrosion of uranium metal has exceedingly fine particle size ( $6 \mathrm{~nm}$ diameter) and that the particles also evidently agglomerate. The particle size was measured by two independent means.

- Showed that the uraninite produced by anoxic uranium metal corrosion has the formula $\mathrm{UO}_{2.004 \pm 0.007}$; i.e., is practically stoichiometric $\mathrm{UO}_{2}$.

- Showed that the $\mathrm{UO}_{2}$ produced by uranium metal corrosion in anoxic water is susceptible to oxidation by atmospheric oxygen. This was demonstrated by bubbling oxygen gas through uraninite water suspensions. The oxidation rate increases with increasing temperature.

- Showed that the oxidation of $\mathrm{UO}_{2}$ with oxygen produces metaschoepite, $\mathrm{UO}_{3} \cdot 2 \mathrm{H}_{2} \mathrm{O}$. The metaschoepite particles are flatter and wider when prepared at $21^{\circ} \mathrm{C}$ than the particles prepared at $50^{\circ} \mathrm{C}$. These particles are much smaller than the metaschoepite observed in prolonged exposure of actual $\mathrm{K}$ Basin sludge to warm moist oxidizing conditions.

- Characterized both the uraninite produced by anoxic uranium metal corrosion and the metaschoepite produced by reaction of uraninite aqueous slurries with oxygen for their use in engineering and process development testing.

- Led to proposal of a method to determine uranium metal concentrations in sludge by a selective dissolution technique. The technique is based on the observation in the present testing that the dissolution rate of uranium oxide is vastly more rapid than that of uranium metal in phosphoric acid. The selective dissolution technique to determine uranium metal concentration in sludge is being developed under separate testing.

Because of insufficient isolation from atmospheric contamination, testing to determine whether metaschoepite aqueous slurry reacts with bubbling hydrogen gas at $21^{\circ} \mathrm{C}$ and $50^{\circ} \mathrm{C}$ was inconclusive. An alternative method based on use of the gas generation testing method used in prior studies of reactions in $\mathrm{K}$ Basins sludge is suggested. 


\section{Objectives}

Uraninite [U(IV) dioxide, $\mathrm{UO}_{2}$ ] and metaschoepite [U(VI) oxide hydrate; $\left(\mathrm{UO}_{2}\right)_{8} \mathrm{O}_{2}(\mathrm{OH})_{12}\left(\mathrm{H}_{2} \mathrm{O}\right)_{12}$ or $\mathrm{UO}_{3} \cdot 2 \mathrm{H}_{2} \mathrm{O}$ ] are the uranium phases most frequently observed in actual $\mathrm{K}$ Basin sludge by X-ray diffractometry (XRD). Prior studies with genuine sludge from the K Basins have shown that specific uranium compounds and their alteration may affect the physical and chemical behaviors of products generated from $185^{\circ} \mathrm{C}$ hydrothermal treatment (Delegard et al. 2007a). The present work was performed to obtain uraninite, prepared by a commercial vendor via anoxic corrosion of uranium metal, oxidize aqueous suspensions of uraninite with dissolved oxygen gas to form metaschoepite, and characterize the uraninite, metaschoepite, and the reaction intermediates. Separate studies also were undertaken to determine if dissolved hydrogen gas is scavenged by metaschoepite to form reduced uranium compounds such as uraninite, ianthinite, or uranium octaoxide.

Pure uraninite and metaschoepite compounds were to serve as feed material for further hydrothermal treatment tests that had been planned in accordance with Sludge Treatment Project (STP) corrosion process chemistry follow-on testing (Delegard et al. 2007b). Although most of the planned hydrothermal testing was cancelled in July 2007 (as described in the forward of Delegard et al. 2007b), uranium oxide procurement and lab tests on the preparation of metaschoepite by reaction of uraninite with oxygen, reaction of hydrogen with metaschoepite, and characterization of the various starting, product, and intermediate materials were continued to improve the understanding of uranium oxide chemistry in sludge and to provide well-characterized uranium oxides suited to support study of evolving STP processing alternatives (Sloughter 2007). ${ }^{\text {(a) }}$ Testing with well characterized uranium oxide provides better experimental control and is significantly less costly than equivalent testing with the highly radioactive genuine sludge.

The work described in the present letter report was performed by the Pacific Northwest National Laboratory (PNNL), under the direction of the STP managed by Fluor Hanford, in accordance with the statement of work for Project 53451 under Contract 27647-242, ${ }^{(b)}$ as modified by Sloughter (2007).

\section{Key Accomplishments}

Uranium Oxide Preparation and Characterization. Approximately $10 \mathrm{~kg}$ of uranium oxide was prepared under contract for PNNL by corrosion of pure uranium metal in $60^{\circ} \mathrm{C}$ anoxic water. Physical and chemical characterization of the product by PNNL showed it to be uraninite with formula $\mathrm{UO}_{2.004 \pm 0.007}$ having individual crystallite size of $\sim 6 \mathrm{~nm}$ with some amount of larger agglomerates. The stoichiometry was determined by a spectrophotometric technique developed for the present work. The particle size was estimated by evaluation of the rate of the uraninite reaction with dissolved oxygen gas to form metaschoepite and comparing with published surface area-specific rates. The particle size was confirmed independently by an XRD technique. The particle size findings accord with observations presented in published research on the hydrothermal $90^{\circ} \mathrm{C}$ anoxic corrosion of irradiated $\mathrm{N}$ Reactor fuel and $30^{\circ} \mathrm{C}$

(a) Sloughter, JP. 2007. Memorandum, "Direction to PNNL for Hydrothermal Treatment of K Basin Sludge Contract 27647-242," Jim Sloughter (FH-BTR) to AJ Schmidt (PNNL), July 18, 2007. Transmitted via email, "Contract 27647-242 Direction," JP Sloughter to AJ Schmidt, 7/18/2007, 4:14 PM.

(b) SOW. 2007. Statement of Work, "Prepare for High Temperature Sludge Process Testing - Additional Task for 'Statement of Work: Technical Services Providing Bench Scale Testing of High Temperature Process Conditions for K Basin Sludge Treatment." accompanying the transmittal of Contract 27647-242 on April 5, 2007. 
anoxic corrosion of non-irradiated N Reactor fuel. The settled density of the aqueous slurry, $\sim 2.4 \mathrm{~g} / \mathrm{cm}^{3}$, is consistent with the density of uranium-rich canister sludges from the $\mathrm{K}$ Basin.

Metaschoepite was prepared by reaction of aqueous uraninite suspensions with bubbling oxygen gas at both $21^{\circ} \mathrm{C}$ and $50^{\circ} \mathrm{C}$. The reaction rate was higher at $50^{\circ} \mathrm{C}$ and the product metaschoepite particles were thicker and more rounded than the products obtained at $21^{\circ} \mathrm{C}$. The metaschoepite was identified by XRD and the particle size and shape by scanning electron microscopy. The XRD results match those of $\mathrm{K}$ Basin sludge, particularly that of uranium-rich sludge that has been stored for extended periods under warm moist conditions in the hot cell. The metaschoepite particles prepared in the present tests, however, are significantly smaller than those of actual K Basin sludge stored in the hot cell.

The progress of the uraninite oxidation reaction was followed by spectrophotometric analysis of the uranium oxidation state in the solids and by noting the color of the slurry. About $70 \%$ reaction to metaschoepite was required before a noticeable lightening of the intensely black uraninite occurred. About 90\% reaction was required before the solids acquired a green color. Pure metaschoepite is yellowgreen. The metaschoepite produced after 59 days of oxidation at both temperatures still contained some reduced uranium, evident by the spectrophotometric technique ( $\sim 99 \%$ conversion to metaschoepite), the presence of residual black particles, and the presence of ianthinite, a uranium oxide/hydroxide hydrate with oxidation state of $5.33 \overline{3}$ instead of 6 as for metaschoepite, as determined by XRD. The settled densities of the metaschoepite product and of the intermediate uraninite/metaschoepite mixtures decreased in a near linear rate as a function of conversion from $2.4 \mathrm{~g} / \mathrm{cm}^{3}$ for pure uraninite to $1.2 \mathrm{~g} / \mathrm{cm}^{3}$ for nearly pure metaschoepite. The metaschoepite product density is much lower than the densities (generally $>2 \mathrm{~g} / \mathrm{cm}^{3}$ ) observed for oxidized uranium-rich K Basin sludge possibly because the particles are finer, flatter, and thus less readily packed.

The uraninite produced by the vendor by anoxic $60^{\circ} \mathrm{C}$ aqueous corrosion of uranium metal can be used as a chemical and physical surrogate for the chemically reduced uranium oxides present in Settler Tube or canister sludge. By the present laboratory experiments, means have been identified to convert uraninite to metaschoepite. Both uranium oxides may be used for future operations and waste qualification purposes such as waste form reactions, tests of rheology modifiers, grouting, and filtration.

Uranium Oxide Speciation Method Development. A robust spectrophotometric analytical technique to determine the distribution of U(VI) and U(IV) in sludge oxide solids was developed, demonstrated, and validated. This technique potentially can be deployed in a hot cell environment but also is applicable outside the hot cell. The method achieves U(IV) and U(VI) quantitation limits to about $0.001 \mathrm{M}$ uranium. These concentrations are easily attained for K Basin sludge. The presence of iron, a common component of K Basin sludge, can influence the spectrophotometric uranium speciation results but its effect can be assessed quantitatively by further spectral analysis.

Kinetic Evaluation of Conversion of $U(I V)$ to $U(V I)$. A laboratory/bench scale approach to convert U(IV) to U(VI) oxide by oxidation with pure oxygen was demonstrated and the kinetics established at two temperatures. The additional knowledge of this reaction gained in the present work enhances understanding of the behavior of uranium oxide in $\mathrm{K}$ Basin sludge.

Kinetic Evaluation of the Scavenging of Hydrogen by Reaction with U(VI) Oxides. It has been postulated that some fraction of hydrogen gas generated during anoxic aqueous corrosion of uranium metal is consumed by chemically reducing U(VI) solid phases to form U(IV) phases. Testing, by bubbling hydrogen gas at atmospheric pressure through metaschoepite and mixtures of metaschoepite with uraninite, were performed to verify and quantify this reaction pathway for metaschoepite and to quantify the reaction kinetics. The tests were inconclusive because the very finely particulate U(IV) solids or 
U(IV) coatings which might have formed, if present, would have been easily re-oxidized before analysis. An alternative method which isolates the system from interference by atmospheric oxygen is necessary to study this reaction. Thermostatted closed vessels with gas pressure measurement, such as used in the gas generation testing (e.g., Delegard et al. 2000), would provide the necessary isolation while allowing sensitive monitoring of reaction progress.

Formulation of Alternative Method to Quantify Uranium Metal in Sludge. Based on observations and measurements performed during uranium oxide characterization and kinetics studies, a selective sludge dissolution approach was identified that potentially can provide a rapid technique to determine uranium metal concentration in sludge. Uranium oxides dissolve rapidly in concentrated phosphoric acid under conditions wherein very little uranium metal dissolution occurs. Because of this difference, a selective dissolution of uranium oxides away from the uranium metal can occur. The dissolved uranium oxides can be decanted and the residual solids containing the uranium metal rinsed free of the dissolved oxides with serial dilute nitric acid washes. A subsequent strike of the phosphoric acid insoluble fraction with strong heated nitric acid dissolves the uranium metal. The resulting acid digestate can be analyzed for uranium via standard analytical techniques to determine uranium metal concentration. Further development and demonstration of this technique are underway as part of a follow-on activity. 


\section{Acknowledgements}

The authors greatly appreciate the programmatic and technical oversight provided by Ron Baker and Jim Sloughter of the Sludge Treatment Project.

The uranium dioxide, $\mathrm{UO}_{2}$, slurry was prepared by Larry Koran of Material Sciences Corporation (MSC), Oak Ridge, Tennessee. Technical consultation and execution of the work at MSC was coordinated by Mel Lundberg.

The authors also gratefully acknowledge the support of other project staff at PNNL in performing the laboratory test operations, sample analyses, quality oversight, and report review and preparation.

X-ray Diffractometry - The X-ray diffraction sample scans were run by Matt Edwards and the scans interpreted by Evan Jenson.

Sample imaging - Scanning electron microscopy (SEM) and energy dispersive spectroscopy (EDS) were conducted by Paul MacFarlan.

Quality - Quality Engineering and Quality Assurance support was provided by Alice Lewis.

Report review and preparation - Susan Jones reviewed the report and suggested important technical changes. The report was formatted and prepared for publication by Brenda Thornton. 



\section{Contents}

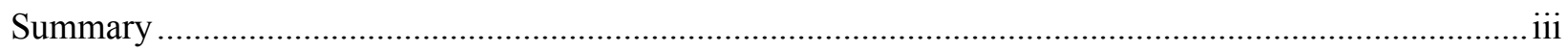

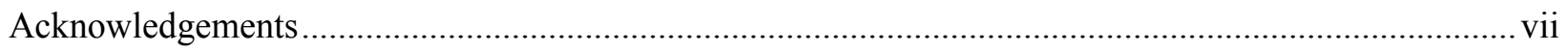

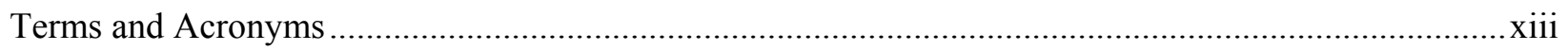

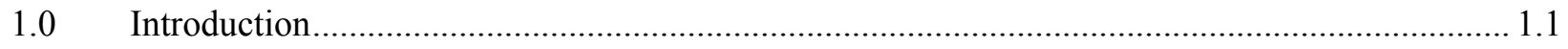

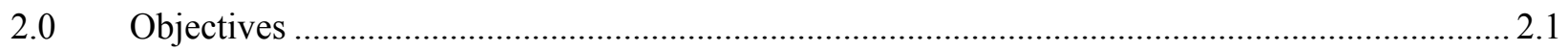

3.0 Determination of Uranium Oxidation State by Absorption Spectrophotometry .............................. 3.1

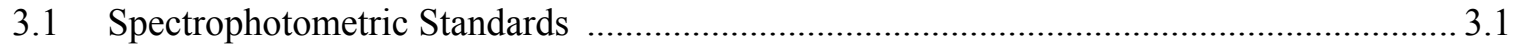

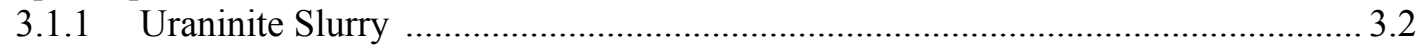

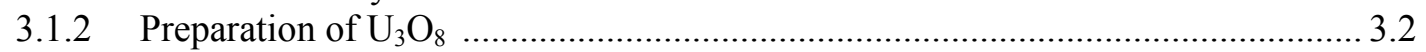

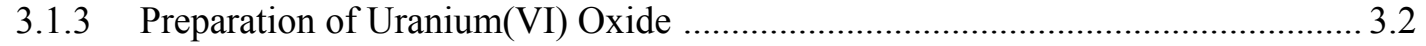

3.1.4 Preparation of Uranium(VI) Standard Solutions ............................................... 3.3

3.1.5 Preparation of Uranium(IV) Standard Solutions .................................................. 3.3

3.1.6 Preparation of Mixed Uranium(IV,VI) Standard Solutions from $\mathrm{U}_{3} \mathrm{O}_{8} \ldots \ldots \ldots \ldots \ldots . . . . .3 .4$

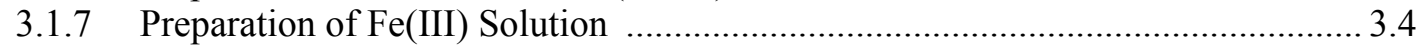

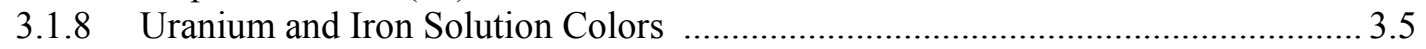

3.2 Absorbance Measurements of the Spectrophotometric Standards ................................... 3.5

3.2.1 Influence of Water on (U(IV) and U(VI) Absorbance Spectra .............................. 3.7

3.2.2 Influence of Heat, Time, and Light on U(VI) Absorbance Spectra........................ 3.9

3.2.3 Beer-Lambert Fit of Calibration Standard Absorbance Spectra ............................ 3.9

3.2.4 Application of the Beer-Lambert Law to Determine U(IV) and U(VI) Concentrations .................................................................................. 3.11

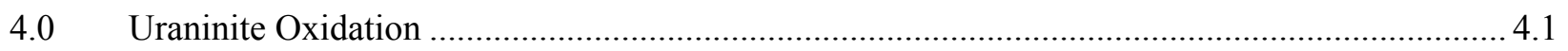

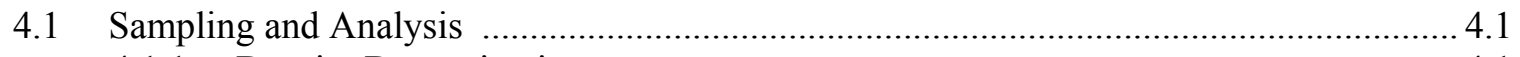

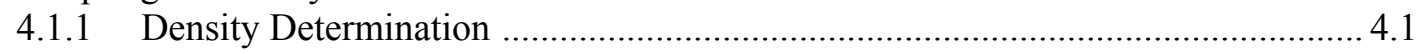

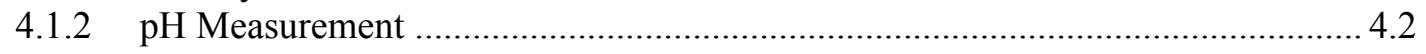

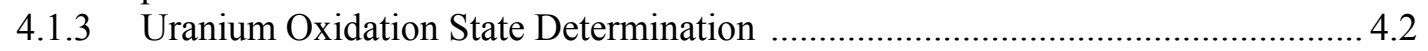

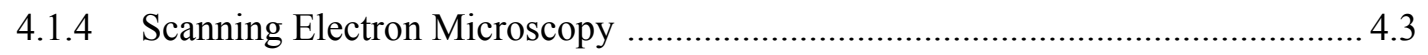

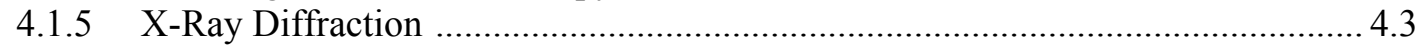

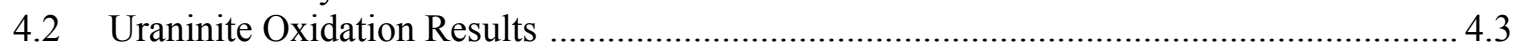

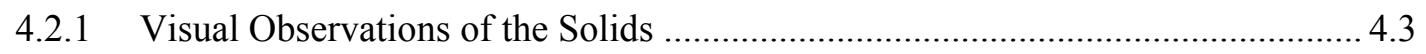

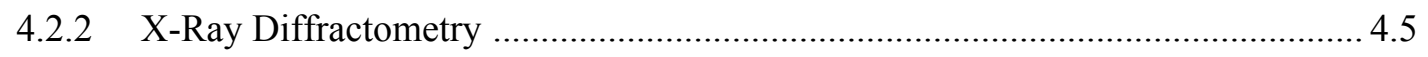

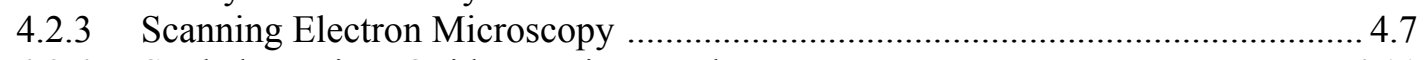

4.2.4 Settled Uranium Oxide Density Results ........................................................ 4.11

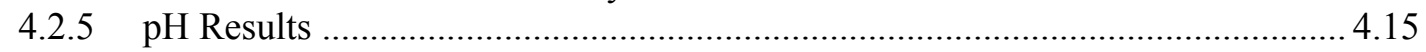

4.2.6 Uranium Oxidation State Results .............................................................. 4.15

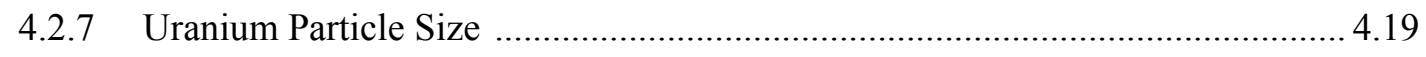

4.2.8 Effect of Temperature on Uraninite Oxidation Rate ...................................... 4.21 
PNNL-17678

\section{Contents (cont'd)}

5.0 Kinetic Evaluation of the Scavenging of $\mathrm{H}_{2}$ by Reaction with U(VI) Solid Phases ................... 5.1

5.1 Experimental Apparatus, Testing, and Analysis .............................................................. 5.1

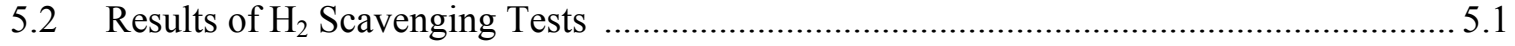

6.0 Potential Analysis of Uranium Metal in Sludge by Selective Dissolution ................................. 6.1

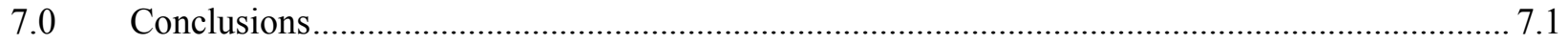

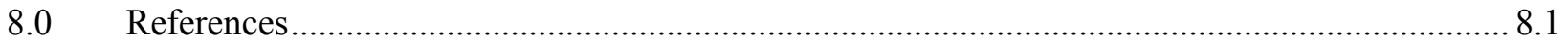

Appendix A, Preparation and Properties of Uraninite Received from Materials Sciences

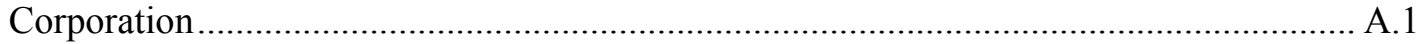




\section{Figures}

3.1 Primary Uranium Spectrophotometric Standards, U3O8 Validation Standard, and $\mathrm{Fe}$ (III) in $\mathrm{Na}_{2} \mathrm{SO}_{4}$-bearing $\mathrm{H}_{3} \mathrm{PO}_{4}$

3.2 Molar Extinction Coefficients of U(IV) and U(VI) Standards and of Fe(III) in $\mathrm{Na}_{2} \mathrm{SO}_{4}-\mathrm{H}_{3} \mathrm{PO}_{4}$

3.3 Absorbance Measurements of $\mathrm{U}(\mathrm{VI})$ in $\mathrm{Na}_{2} \mathrm{SO}_{4}$-Bearing $\mathrm{H}_{3} \mathrm{PO}_{4}$ at Varying $\mathrm{H}_{3} \mathrm{PO}_{4}$ Concentration

3.4 Absorbance Measurements of $\mathrm{U}(\mathrm{IV})$ in $\mathrm{Na}_{2} \mathrm{SO}_{4}$-Bearing $\mathrm{H}_{3} \mathrm{PO}_{4}$ at Varying $\mathrm{H}_{3} \mathrm{PO}_{4}$ Concentration

3.5 Beer-Lambert Determination of Molar Extinction Coefficients for U(IV) at 406.2 and $642.6 \mathrm{~nm}$

3.6 Beer-Lambert Determination of Molar Extinction Coefficients for U(VI) at 406.2 and $642.6 \mathrm{~nm}$

4.1 Syringe Apparatus Used to Determine Settled Slurry Density .............................................. 4.2

4.2 Samples from Uraninite Oxidation by Bubbling $\mathrm{O}_{2}$ for 0 to $\sim 7$ Days ..........................................4 4.4

4.3 Samples from Uraninite Oxidation by Bubbling $\mathrm{O}_{2}$ for $\sim 2$ to 11 Days .................................... 4.4

4.4 Close-up View of 10.90-day Sample from $50^{\circ} \mathrm{C}$ Test ............................................................ 4.5

4.5 Samples from Uraninite Oxidation by Bubbling $\mathrm{O}_{2}$ for $\sim 32$ to 53 Days ................................... 4.5

4.6 X-Ray Diffraction Patterns for Starting Uraninite, $21^{\circ} \mathrm{C}$ and $50^{\circ} \mathrm{C}$ Product ............................ 4.6

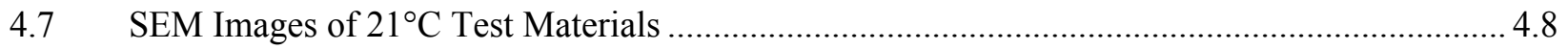

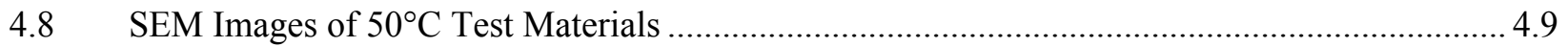

4.9 Images of $\mathrm{KC}-2 / 3 \mathrm{M} 250$ Sludge and $21^{\circ} \mathrm{C}$ and $50^{\circ} \mathrm{C}$ Metaschoepite Products ....................... 4.10

4.10 Settled Solids Densities for Uraninite-Metaschoepite Mixtures .............................................. 4.12

4.11 Settled Solids Density as a Function of Conversion from Pure Uraninite ( $0 \%$ Conversion) to Pure Metaschoepite (100\% Converstion)

$4.12 \mathrm{pH}$ Values for Uraninite-Metaschoepite Mixtures......................................................... 4.16

4.13 Conversion of Uraninite to Metaschoepite as a Function of Time ........................................ 4.17

4.14 Shrinking Core Kinetics Plots of $21^{\circ} \mathrm{C}$ and $50^{\circ} \mathrm{C}$ Uraninite Oxidation Tests.......................... 4.18 
PNNL-17678

\section{Figures (cont'd)}

4.15 Modeling $21^{\circ} \mathrm{C}$ Uraninite Oxidation....... 4.21

5.1 Uranium(VI) Concentrations in Solids from Tests of Metaschoepite Reduction by $\mathrm{H}_{2}$ 5.2

\section{Tables}

1.1 Free Energy of Formation Calculation for the Reduction of Metaschoepite by Hydrogen Gas to Form Uraninite

3.1 Concentrations of Uranium (VI) in U(VI) Absorbance Standard Solutions ............................... 3.3

3.2 Concentrations of Uranium (IV) in U(IV) Absorbance Standard Solutions ................................ 3.4

3.3 Concentrations of Uranium (IV) and Uranium(VI) in $\mathrm{U}_{3} \mathrm{O}_{8}$ Absorbance Standard

Solutions

3.4 Molar Extinction Coefficients for U(IV) and U(VI) Solutions in $\mathrm{Na}_{2} \mathrm{SO}_{4}-\mathrm{H}_{3} \mathrm{PO}_{4}$

Solution......

3.5 Oxidation State Concentrations and Distributions for $\mathrm{U}_{3} \mathrm{O}_{8}$ Spectrophotometric Standards.

4.1 Settled Solids Densities for Uraninite-Metaschoepite Mixtures.

4.2 Settled Densities, Uranium Concentrations, and Phases Identified in Uranium-Rich K Basin Sludges.

4.3 Hydrate Formula for Metaschoepite Products

4.4 $\mathrm{pH}$ Values for Uraninite-Metaschoepite Mixtures

4.5 Oxidation State Distributions in $21^{\circ} \mathrm{C}$ and $50^{\circ} \mathrm{C}$ Oxidation Test Samples as a Function of Time

4.6 Kinetic Parameters for Uraninite Oxidation by Dissolved Oxygen at $21^{\circ} \mathrm{C}$ and $50^{\circ} \mathrm{C}$.

4.7 Model Particle Size Bins and Volume Distributions for $21^{\circ} \mathrm{C}$ Test.

5.1 Oxidation State Distributions in $21^{\circ} \mathrm{C}$ and $50^{\circ} \mathrm{C}$ Reduction Test Samples as a Function of Time 
PNNL-17678

\section{Terms and Acronyms}

Terms and acronyms used within this report are described below.

$\underline{\text { Term }}$

EDS

KPA

MSC

PNNL

RPL

SEM

STP

TEM

XRD

\section{$\underline{\text { Explanation }}$}

Energy Dispersive Spectroscopy

Kinetic Phosphorescence Analysis

Material Sciences Corporation

Pacific Northwest National Laboratory

Radiochemical Processing Laboratory

Scanning Electron Microscopy

Sludge Treatment Project

Transmission Electron Microscopy

X-ray diffraction or diffractometry 


\subsection{Introduction}

The objective of this work is to synthesize metaschoepite from uraninite and to characterize the reactant uraninite $\left(\mathrm{UO}_{2 . \mathrm{x}}\right)$, product metaschoepite $\left[\left(\mathrm{UO}_{2}\right)_{8} \mathrm{O}_{2}(\mathrm{OH})_{12}\left(\mathrm{H}_{2} \mathrm{O}\right)_{12}\right.$, equivalent to $\left.\mathrm{UO}_{3} \cdot 2 \mathrm{H}_{2} \mathrm{O}\right]$, and intermediate materials. The work was performed in partial fulfillment of a test plan for the $\mathrm{K}$ Basin project (Delegard et al. 2007a) and under an approved Test Instruction. ${ }^{\text {(a) }}$ The techniques used to synthesize metaschoepite at lab- (gram-) scale quantities developed in this work may be used to prepare larger (kg-scale) quantities for engineering testing under separate activities. Work also was performed to determine if hydrogen gas $\left(\mathrm{H}_{2}\right)$ is scavenged by reaction with aqueous suspensions of metaschoepite.

The presence of uranium metal, uraninite, and metaschoepite as well as more mineralized forms of uranium has been revealed in prior studies of $\mathrm{K}$ Basin sludge. The uranium metal has been identified by the generation of hydrogen gas and the release of isotopes, in the correct ratios, of the fission product gases krypton and xenon. The uraninite arises from the anoxic corrosion of uranium metal in water:

$$
\mathrm{U}+(2+0 . \mathrm{x}) \mathrm{H}_{2} \mathrm{O} \rightarrow \mathrm{UO}_{2 . \mathrm{x}}+(2+0 . \mathrm{x}) \mathrm{H}_{2}
$$

while metaschoepite arises from the reaction of uraninite with oxygen gas $\left(\mathrm{O}_{2}\right)$ dissolved in the water:

$$
\mathrm{UO}_{2 . \mathrm{x}}+(0.5-0.5 \times 0 . \mathrm{x}) \mathrm{O}_{2}+2 \mathrm{H}_{2} \mathrm{O} \rightarrow \mathrm{UO}_{3} \cdot 2 \mathrm{H}_{2} \mathrm{O}
$$

The reaction of dissolved hydrogen gas with metaschoepite aqueous slurries is also thermodynamically possible (Table 1.1) and thus may occur:

$$
\mathrm{UO}_{3} \cdot 2 \mathrm{H}_{2} \mathrm{O}+\mathrm{H}_{2} \rightarrow \mathrm{UO}_{2}+3 \mathrm{H}_{2} \mathrm{O}
$$

\begin{tabular}{|c|c|c|}
\hline Compound & $\Delta_{\mathrm{f}} \mathrm{G}^{\circ}, \mathrm{kJ} / \mathrm{mole}^{(\mathrm{a})}$ & $\Delta_{\mathrm{f}} \mathbf{G}^{\circ}, \mathbf{k J}$ \\
\hline \multicolumn{3}{|l|}{ Reactants } \\
\hline $\mathrm{UO}_{3} \cdot 2 \mathrm{H}_{2} \mathrm{O}$ & -1630.8 & -1630.8 \\
\hline $\mathrm{H}_{2}$ & 0.0 & 0.0 \\
\hline \multicolumn{3}{|l|}{ Products } \\
\hline $\mathrm{UO}_{2}$ & -1031.7 & -1031.7 \\
\hline $\mathrm{H}_{2} \mathrm{O}$ & -237.129 & -711.387 \\
\hline \multicolumn{2}{|c|}{$\Delta_{\mathbf{r}} \mathbf{G}^{\circ}, \mathbf{k J} / \mathbf{m o l e}, \mathrm{UO}_{3} \cdot 2 \mathrm{H}_{2} \mathrm{O}+\mathrm{H}_{2} \rightarrow \mathrm{UO}_{2}+3 \mathrm{H}_{2} \mathrm{O}$} & -112.3 \\
\hline
\end{tabular}

Table 1.1. Free Energy of Formation Calculation for the Reduction of Metaschoepite by Hydrogen Gas to Form Uraninite

This work was performed using uraninite that had been prepared off-site by anoxic aqueous corrosion of uranium metal at $60^{\circ} \mathrm{C}$. The uraninite was oxidized to the compound metaschoepite in the Radiochemical Processing Laboratory (RPL) of the PNNL by bubbling oxygen gas through uraninite aqueous suspensions. The uraninite, product metaschoepite, and samples of the suspensions taken at intermediate times in the oxidation were characterized by their uranium oxidation state [U(IV) and U(VI)], settled

(a) Delegard, CH. 2007. Preparation of Metaschoepite from Uraninite and Characterization of the Reactants and Product, Test Instruction 53451 TI03, Pacific Northwest National Laboratory, Richland, WA. 
solids densities, the associated solution $\mathrm{pH}$, and the settled solids appearances by visual (photographic) and scanning electron microscopic viewing. The starting uraninite and product metaschoepite solid phases also were characterized by XRD. Studies of the potential reaction of metaschoepite with hydrogen to form uraninite were performed by a similar gas bubbling technique.

Determinations of uranium oxidation state in the starting uraninite, the reacting mixtures, and the reaction products were performed by an absorption spectrometric method developed for this experimental program.

The objectives of this work and the results of these studies are presented in the following report. 


\subsection{Objectives}

Uraninite and metaschoepite are the uranium phases most frequently observed in actual K Basin sludge. Prior studies with genuine sludge from the $\mathrm{K}$ Basins have shown that the types of uranium compounds in sludge can affect the physical and chemical behaviors of products generated from $185^{\circ} \mathrm{C}$ hydrothermal treatment (Delegard et al. 2007a). The present work was performed to obtain uraninite, prepared by a commercial vendor via anoxic corrosion of uranium metal, oxidize a portion of the uraninite with dissolved oxygen gas to form metaschoepite, and characterize the uraninite, metaschoepite, and the reaction intermediates. Separate studies also were undertaken to determine if metaschoepite will react with dissolved hydrogen gas and potentially form reduced uranium compounds such as uraninite, ianthinite $\left[\mathrm{U}_{2}\left(\mathrm{UO}_{2}\right)_{4} \mathrm{O}_{6}(\mathrm{OH})_{4}\left(\mathrm{H}_{2} \mathrm{O}\right)_{4} \cdot 5 \mathrm{H}_{2} \mathrm{O}\right]$, or uranium octaoxide $\left(\mathrm{U}_{3} \mathrm{O}_{8}\right)$.

Uraninite and metaschoepite were to serve as feed material for further hydrothermal treatment tests that had been planned in accordance with Sludge Treatment Project (STP) corrosion process chemistry follow-on testing (Delegard et al. 2007b). Although most of the planned hydrothermal testing was cancelled in July 2007 (as described in the forward of Delegard et al. 2007b), uranium oxide procurement and lab tests on the preparation of metaschoepite by reaction of uraninite with oxygen, reaction of hydrogen with metaschoepite, and characterization of the various starting, product, and intermediate materials were continued to improve the understanding of uranium oxide chemistry in sludge and to provide well-characterized uranium oxides suited to support evolving STP initiatives (Sloughter 2007). Testing with well characterized uranium oxide provides better experimental control and is significantly less costly that equivalent testing with the highly radioactive genuine sludge.

The work described in the present letter report was performed by the PNNL, under the direction of the Sludge Treatment Project managed by Fluor Hanford, in accordance with the statement of work for Project 53451 under Contract 27647-242, ${ }^{\text {(a) }}$ as modified by Sloughter (2007). ${ }^{\text {(b) }}$

(a) SOW. 2007. Statement of Work, "Prepare for High Temperature Sludge Process Testing - Additional Task for 'Statement of Work: Technical Services Providing Bench Scale Testing of High Temperature Process Conditions for K Basin Sludge Treatment.'” accompanying the transmittal of Contract 27647-242 on April 5, 2007.

(b) Sloughter, JP. 2007. Memorandum, "Direction to PNNL for Hydrothermal Treatment of K Basin Sludge Contract 27647-242," Jim Sloughter (FH-BTR) to AJ Schmidt (PNNL), July 18, 2007. Transmitted via email, "Contract 27647-242 Direction," JP Sloughter to AJ Schmidt, 7/18/2007, 4:14 PM. 


\subsection{Determination of Uranium Oxidation State by Absorption Spectrophotometry}

Measurement of the relative distribution of tetravalent and hexavalent uranium [U(IV) and U(VI), respectively] in the starting uraninite, the product metaschoepite, and in the intermediate materials was determined by dissolution of samples of the materials in phosphoric acid and measurement of the characteristic U(IV) and U(VI) solution spectra by optical absorption spectrophotometry.

The spectrophotometric analyses were performed by dissolution of the uranium oxide slurries in $85 \mathrm{wt} \%$ $(14.6 \mathrm{M})$ phosphoric acid $\left(\mathrm{H}_{3} \mathrm{PO}_{4}\right)$ solution that is near saturation in dissolved sodium sulfate $\left(\mathrm{Na}_{2} \mathrm{SO}_{4}\right)$ and measurement of the spectrophotometric absorbances in comparison with the spectra of dissolved uranium of known concentration and oxidation state (Ahmed and Sreenivasan 1986). The $\mathrm{Na}_{2} \mathrm{SO}_{4}-\mathrm{H}_{3} \mathrm{PO}_{4}$ solution composition was selected to minimize, by complexation, oxidation of U(IV) by atmospheric oxygen and eliminate the need for an inert atmosphere glovebox as practiced in other spectrophotometric methods. The reagent quantities were 2.00 grams of $\mathrm{Na}_{2} \mathrm{SO}_{4}$ dissolved in $100 \mathrm{ml}$ of $85 \mathrm{wt} \% \mathrm{H}_{3} \mathrm{PO}_{4}$ to produce $\sim 0.141 \mathrm{M} \mathrm{Na}_{2} \mathrm{SO}_{4}$. This solution was used in all spectrophotometric measurements.

The applicability of the Beer-Lambert Law was verified by acquiring optical absorption spectra and determining molar absorptivities for solutions of known uranium oxidation state and concentration prepared from well characterized uranium materials. The Beer-Lambert Law:

$$
\mathrm{A}=\varepsilon \mathrm{bc}
$$

states that the light absorbance, A, measured by the spectrophotometer is a linear function of the molar extinction coefficient, $\varepsilon$, the path length of light through the solution, b, and the solution concentration, $c$. The path length normally is measured in centimeters, the concentration in moles per liter, and the molar extinction coefficient in units of liters $/$ mole $\cdot \mathrm{cm}$. Therefore, the absorbance, A, is dimensionless. The Beer-Lambert Law was applied to the determination of U(IV) and U(VI) concentrations in the uraninitemetaschoepite solid material mixtures dissolved in $\mathrm{Na}_{2} \mathrm{SO}_{4}-\mathrm{H}_{3} \mathrm{PO}_{4}$ solutions.

\subsection{Spectrophotometric Standards}

Uranium(VI) oxide, $\mathrm{UO}_{3}$, and $\mathrm{U}$ metal, were used, respectively, to prepare the U(VI) and U(IV) spectrophotometric standards. The $\mathrm{UO}_{3}$ was prepared by calcining a portion of uraninite slurry of known uranium purity obtained from a commercial source to stoichiometric uranium octaoxide, $\mathrm{U}_{3} \mathrm{O}_{8}$, dissolving and oxidizing accurately weighed portions of $\mathrm{U}_{3} \mathrm{O}_{8}$ to the $\mathrm{U}(\mathrm{VI})$ state in nitric acid, fuming the solution to dry salts ensure full oxidation to U(VI), dissolving the salts in nitric acid, then drying and calcining at $400^{\circ} \mathrm{C}$ to make $\mathrm{UO}_{3}$. The uranium metal used in the testing was taken from laboratory stock of known purity. Uranium octaoxide also was used as a mixed U(IV)-U(VI) spectrophotometric standard to verify that $\mathrm{U}(\mathrm{IV}): \mathrm{U}(\mathrm{VI})$ is found in the expected 1:2 mole ratio $\left(\mathrm{U}_{3} \mathrm{O}_{8}\right.$ is equivalent to $\left.\mathrm{UO}_{2}+2 \mathrm{UO}_{3}\right)$ and that the spectrophotometric technique accurately determines $\mathrm{U}(\mathrm{IV})$ and $\mathrm{U}(\mathrm{VI})$ solution concentrations. The properties of the uraninite slurry and the preparation of $\mathrm{U}_{3} \mathrm{O}_{8}, \mathrm{UO}_{3}$, and the spectrophotometric standards are described. 


\subsubsection{Uraninite Slurry}

The unirradiated bulk uraninite slurry was synthesized under conditions near-prototypical of those in the K Basins by Material Sciences Corporation (MSC) of Oak Ridge, TN, specifically for this and related $\mathrm{K}$ Basin process testing. To match the properties of the $\mathrm{UO}_{2 . \mathrm{x}}$ found in the $\mathrm{K}$ Basin sludge, the $\mathrm{UO}_{2 . \mathrm{x}}$ was produced by the reaction of uranium metal turnings (chips) in anoxic water. The turnings $(\sim 0.045$-inch or $\sim 1.1$-mm thickness) were shaved from massive uranium metal pieces with machining equipment, the turnings washed free of the accompanying cutting fluid, and the turnings placed in anoxic water for reaction. Uranium metal reacts slowly in anoxic water at $\mathrm{K}$ Basin temperatures $(\sim 0.0021 \mu \mathrm{m}$ corrosion depth per hour at $15^{\circ} \mathrm{C}$ ). Therefore, the reaction was conducted at $60^{\circ} \mathrm{C}$ (reaction rate $\sim 0.1 \mu \mathrm{m} / \mathrm{h}$ ), a rate increase of a factor of $\sim 50$. Appendix G of Plys and Schmidt (2006) provides the uranium oxidation rate information.

The $10 \mathrm{~kg}$ of uraninite product produced by MSC was shipped to PNNL in two batches as water slurries. The water serves to impede air oxidation of the uraninite, is prototypic of actual $\mathrm{K}$ Basin sludge, and also prevents the uraninite from potential agglomeration caused by dry-out. Both batches from MSC arose from the same starting material. The initial $\sim 500$-g batch was harvested early to allow initiation of testing; uraninite from this batch (bottle 43318 / BRM 11105) was used in the present testing. The $\sim 9.5 \mathrm{~kg}$ balance is reserved for later larger scale engineering tests. The stock uranium metal from which the uraninite was prepared is $99.96 \mathrm{wt} \%$ uranium and is depleted in ${ }^{235} \mathrm{U}$ concentration at approximately 0.19 atom $\%{ }^{235} \mathrm{U}$ (versus 0.72 atom $\%{ }^{235} \mathrm{U}$ in natural uranium) with the balance, 99.81 atom $\%$, being ${ }^{238} \mathrm{U}$. Further information on the uraninite is given in Appendix A.

\subsubsection{Preparation of $\mathrm{U}_{3} \mathrm{O}_{8}$}

Because of its well-characterized stoichiometry, its stability, and its ease of preparation by calcination of uranium metal, uranium oxides, and organic uranium compounds in air above $\sim 700^{\circ} \mathrm{C}, \mathrm{U}_{3} \mathrm{O}_{8}$ frequently is used as a primary gravimetric standard for uranium (Kolthoff et al. 1962). The $\mathrm{U}_{3} \mathrm{O}_{8}$ was prepared for the present testing starting with $\sim 10 \mathrm{ml}$ of settled uraninite aqueous slurry. The uraninite slurry was air-dried overnight and then transferred into a quartz crucible and heated to $800^{\circ} \mathrm{C}$ to oxidize the $\mathrm{UO}_{2 . \mathrm{x}}$ to stoichiometric $\mathrm{U}_{3} \mathrm{O}_{8}$ with atmospheric oxygen.

$$
3 \mathrm{UO}_{2 . \mathrm{x}}+(2-0.3 \mathrm{x}) \mathrm{O}_{2} \rightarrow \mathrm{U}_{3} \mathrm{O}_{8}
$$

The heating continued for 3 hours and then the furnace was cooled to $50^{\circ} \mathrm{C}$. While the crucible was still warm, the $\mathrm{U}_{3} \mathrm{O}_{8}$ was transferred to a capped and labeled glass vial to limit moisture uptake.

\subsubsection{Preparation of Uranium(VI) Oxide}

The uranium(VI) oxide was prepared based on the thermal decomposition of uranyl nitrate (Lister and Richardson 1957; Ondrejcin 1966). The uranyl nitrate was prepared from $\mathrm{U}_{3} \mathrm{O}_{8}$.

First, $0.506 \mathrm{~g}$ of $\mathrm{U}_{3} \mathrm{O}_{8}\left(1.803 \times 10^{-3}\right.$ moles as $\left.\mathrm{U}\right)$ was weighed into a glass vial. The $\mathrm{U}_{3} \mathrm{O}_{8}$ was dissolved in concentrated nitric acid $\left(\mathrm{HNO}_{3}\right)$ and evaporated under a heat lamp to dryness to oxidize the uranium to $\mathrm{U}(\mathrm{VI})$. An aliquot of concentrated $\mathrm{HNO}_{3}$ was added to re-dissolve the dried U(VI) nitrate solids. The resulting solution was evaporated again to dryness to ensure full conversion to U(VI). The dried uranyl nitrate, likely present as $\mathrm{UO}_{2}\left(\mathrm{NO}_{3}\right) \cdot 6 \mathrm{H}_{2} \mathrm{O}$, was heated at $150^{\circ} \mathrm{C}$ overnight to remove water and then heated at $400^{\circ} \mathrm{C}$ for 24 hours to accomplish the denitration and conversion to $\mathrm{UO}_{3}$. 


\subsubsection{Preparation of Uranium(VI) Standard Solutions}

The dried $\mathrm{UO}_{3}$ prepared from $0.506 \mathrm{~g}$ of $\mathrm{U}_{3} \mathrm{O}_{8}$ was dissolved in $\mathrm{Na}_{2} \mathrm{SO}_{4}$-bearing $\mathrm{H}_{3} \mathrm{PO}_{4}$ in the vial in which it had been prepared and then transferred quantitatively to a $25-\mathrm{ml}$ volumetric flask. The volume was adjusted to the $25-\mathrm{ml}$ mark with $\mathrm{Na}_{2} \mathrm{SO}_{4}$-bearing $\mathrm{H}_{3} \mathrm{PO}_{4}$ to make a yellow $7.208 \times 10^{-2} \mathrm{M} \mathrm{U}(\mathrm{VI})$ stock solution and the first absorbance standard.

Quantitative volumetric 5.00-, 2.00-, 1.00-, and 0.50-ml aliquots of the U(VI) stock solution were taken and diluted to $10 \mathrm{ml}$ (with $\mathrm{Na}_{2} \mathrm{SO}_{4}$-bearing $\mathrm{H}_{3} \mathrm{PO}_{4}$ ) in volumetric glassware. These dilutions resulted in four additional U(VI) absorbance standards. The concentrations of U(VI) in the six absorbance standard solutions (including baseline) are compared in Table 3.1.

Table 3.1. Concentrations of Uranium(VI) in U(VI) Absorbance Standard Solutions

\begin{tabular}{||c|l|}
\hline Standard & [U(VI)], M \\
\hline VI-bs1 & 0.0 \\
\hline VI-S1 & 0.003604 \\
\hline VI-S2 & 0.007208 \\
\hline VI-S3 & 0.01442 \\
\hline VI-S4 & 0.03604 \\
\hline VI-S5 & 0.07208 \\
\hline 0.141 M sulfate in all standards. \\
\hline
\end{tabular}

\subsubsection{Preparation of Uranium(IV) Standard Solutions}

The uranium(IV) standard solutions were prepared using uranium metal beads present from laboratory stock. Prior analyses showed the beads to be $99.7 \mathrm{wt} \%$ uranium while energy dispersive spectrometry (EDS) obtained during prior scanning electron microscopy (SEM) of the beads showed iron and aluminum alloying elements at small, but unquantified, concentrations (Delegard et al. 2004).

The uranium(IV) absorbance standard solutions were prepared by first cleaning $\sim 0.16 \mathrm{~g}$ of uranium metal beads in nitric acid to remove the oxide tarnish layer. The nitric acid solution was decanted from the beads when the beads became shiny. The beads were rinsed several times with deionized water, the water decanted, the beads rinsed with ethanol, and the beads air-dried. Then, 0.153 grams $\left(\sim 6.43 \times 10^{-4}\right.$ moles $)$ of the cleaned and dried beads were weighed into a glass vial. About $10 \mathrm{ml}$ of $\mathrm{Na}_{2} \mathrm{SO}_{4}$-bearing $\mathrm{H}_{3} \mathrm{PO}_{4}$ was added to the vial and the vial heated to about $130^{\circ} \mathrm{C}$ to oxidize and dissolve the beads. The beads dissolved very slowly, with minimal bubbling, to produce a green solution. After about one week, the beads still were not completely dissolved. Most of the supernatant liquid was withdrawn and added to a 25-ml volumetric flask and another 10-ml portion of fresh $\mathrm{Na}_{2} \mathrm{SO}_{4}$-bearing $\mathrm{H}_{3} \mathrm{PO}_{4}$ added to the bead residues. About four more days of heating to $130^{\circ} \mathrm{C}$ were required to complete the dissolution.

The cooled solution portions were combined in the 25 - $\mathrm{ml}$ volumetric flask, the vial rinsed with $\mathrm{Na}_{2} \mathrm{SO}_{4}{ }^{-}$ bearing $\mathrm{H}_{3} \mathrm{PO}_{4}$, and the volume brought to the mark with more $\mathrm{Na}_{2} \mathrm{SO}_{4}$-bearing $\mathrm{H}_{3} \mathrm{PO}_{4}$. The U(IV) product stock solution was $2.570 \times 10^{-2} \mathrm{M}$. Quantitative volumetric 5.00-, 2.00-, 1.00-, 0.50-, 0.20-, and $0.10-\mathrm{ml}$ aliquots of the $\mathrm{U}(\mathrm{IV})$ stock were taken and diluted to $10 \mathrm{ml}$ with $\mathrm{Na}_{2} \mathrm{SO}_{4}$-bearing $\mathrm{H}_{3} \mathrm{PO}_{4}$. The U(IV) absorbance solution standard concentrations are shown in Table 3.2. 
Table 3.2. Concentrations of Uranium(IV) in U(IV) Absorbance Standard Solutions

\begin{tabular}{|c|l|}
\hline Standard & {$[\mathbf{U}(\mathbf{I V})], \mathbf{M}$} \\
\hline IV-bs1 & 0 \\
\hline IV-S1 & 0.0002570 \\
\hline IV-S2 & 0.0005140 \\
\hline IV-S3 & 0.001285 \\
\hline IV-S4 & 0.002570 \\
\hline IV-S5 & 0.005140 \\
\hline IV-S6 & 0.01285 \\
\hline IV-S7 & 0.02570 \\
\hline 0.141 M sulfate in all standards. \\
\hline
\end{tabular}

\subsubsection{Preparation of Mixed Uranium(IV,VI) Standard Solutions from $\mathrm{U}_{3} \mathrm{O}_{8}$}

The mixed uranium(IV,VI) absorbance standard solutions were prepared by dissolving 0.504 grams of $\mathrm{U}_{3} \mathrm{O}_{8}$ in $\mathrm{Na}_{2} \mathrm{SO}_{4}$-bearing $\mathrm{H}_{3} \mathrm{PO}_{4}$ in a 25 -ml volumetric flask. The mixture was warmed to $\sim 50^{\circ} \mathrm{C}$ to aid dissolution. The solution was cooled and diluted to the mark with more $\mathrm{Na}_{2} \mathrm{SO}_{4}$-bearing $\mathrm{H}_{3} \mathrm{PO}_{4}$ to make a solution that was $4.786 \times 10^{-2} \mathrm{M} \mathrm{U}(\mathrm{VI})$ and $2.393 \times 10^{-2} \mathrm{M} \mathrm{U}(\mathrm{IV})$. Quantitative volumetric 5.00-, 2.00-, $1.00-, 0.50-, 0.20-$, and $0.10-\mathrm{ml}$ aliquots of the U(IV,VI) stock were taken and diluted to $10 \mathrm{ml}$ with $\mathrm{Na}_{2} \mathrm{SO}_{4}$-bearing $\mathrm{H}_{3} \mathrm{PO}_{4}$. The concentrations of $\mathrm{U}(\mathrm{IV})$ and $\mathrm{U}(\mathrm{VI})$ in the $\mathrm{U}(\mathrm{IV}, \mathrm{VI})$ absorbance solution standards prepared from $\mathrm{U}_{3} \mathrm{O}_{8}$ are shown in Table 3.3.

Table 3.3. Concentrations of Uranium (IV) and Uranium(VI) in $\mathrm{U}_{3} \mathrm{O}_{8}$ Absorbance

Standard Solutions

\begin{tabular}{|c|c|c|}
\hline Standard & {$[\mathbf{U}(\mathbf{I V})], \mathbf{M}$} & {$[\mathbf{U}(\mathbf{V I})], \mathbf{M}$} \\
\hline $38-\mathrm{bs} 1$ & 0 & 0 \\
\hline $38-\mathrm{S} 1$ & 0.0002393 & 0.0004786 \\
\hline $38-\mathrm{S} 2$ & 0.0004786 & 0.0009572 \\
\hline $38-\mathrm{S} 3$ & 0.001197 & 0.002393 \\
\hline $38-\mathrm{S} 4$ & 0.002393 & 0.004786 \\
\hline $38-\mathrm{S} 5$ & 0.004786 & 0.009572 \\
\hline 38-S6 & 0.01197 & 0.02393 \\
\hline 38-S7 & 0.02393 & 0.04786 \\
\hline 0.141 M sulfate in all standards. \\
\hline \multicolumn{2}{|l}{} \\
\hline
\end{tabular}

\subsubsection{Preparation of Fe(III) Solution}

A sample of ferrihydrite $\left[\mathrm{Fe}_{5} \mathrm{O}_{7}(\mathrm{OH}) \cdot 4 \mathrm{H}_{2} \mathrm{O}\right]$ was accurately weighed and dissolved in $\mathrm{Na}_{2} \mathrm{SO}_{4}$-bearing $\mathrm{H}_{3} \mathrm{PO}_{4}$ to make a solution that was $0.75 \mathrm{M}$ in $\mathrm{Fe}(\mathrm{III})$. The ferrihydrite dissolved readily when heated. Separate testing showed that $0.75 \mathrm{M} \mathrm{Fe}$ (III) solution is near saturation in $\mathrm{Na}_{2} \mathrm{SO}_{4}$-bearing $\mathrm{H}_{3} \mathrm{PO}_{4}$. 


\subsubsection{Uranium and Iron Solution Colors}

The three uranium spectrophotometric standards, Figure 3.1, are vividly colored. The U(IV) primary standard color is aqua, the $\mathrm{U}(\mathrm{VI})$ primary standard color is yellow, and the $\mathrm{U}_{3} \mathrm{O}_{8}$ validation standard color is green, a mixture of the $\mathrm{U}(\mathrm{IV})$ aqua and $\mathrm{U}(\mathrm{VI})$ yellow. The $0.75 \mathrm{M} \mathrm{Fe}(\mathrm{III})$ solution in $\mathrm{Na}_{2} \mathrm{SO}_{4}$-bearing $\mathrm{H}_{3} \mathrm{PO}_{4}$, also depicted in Figure 3.1, is a pale rose color.
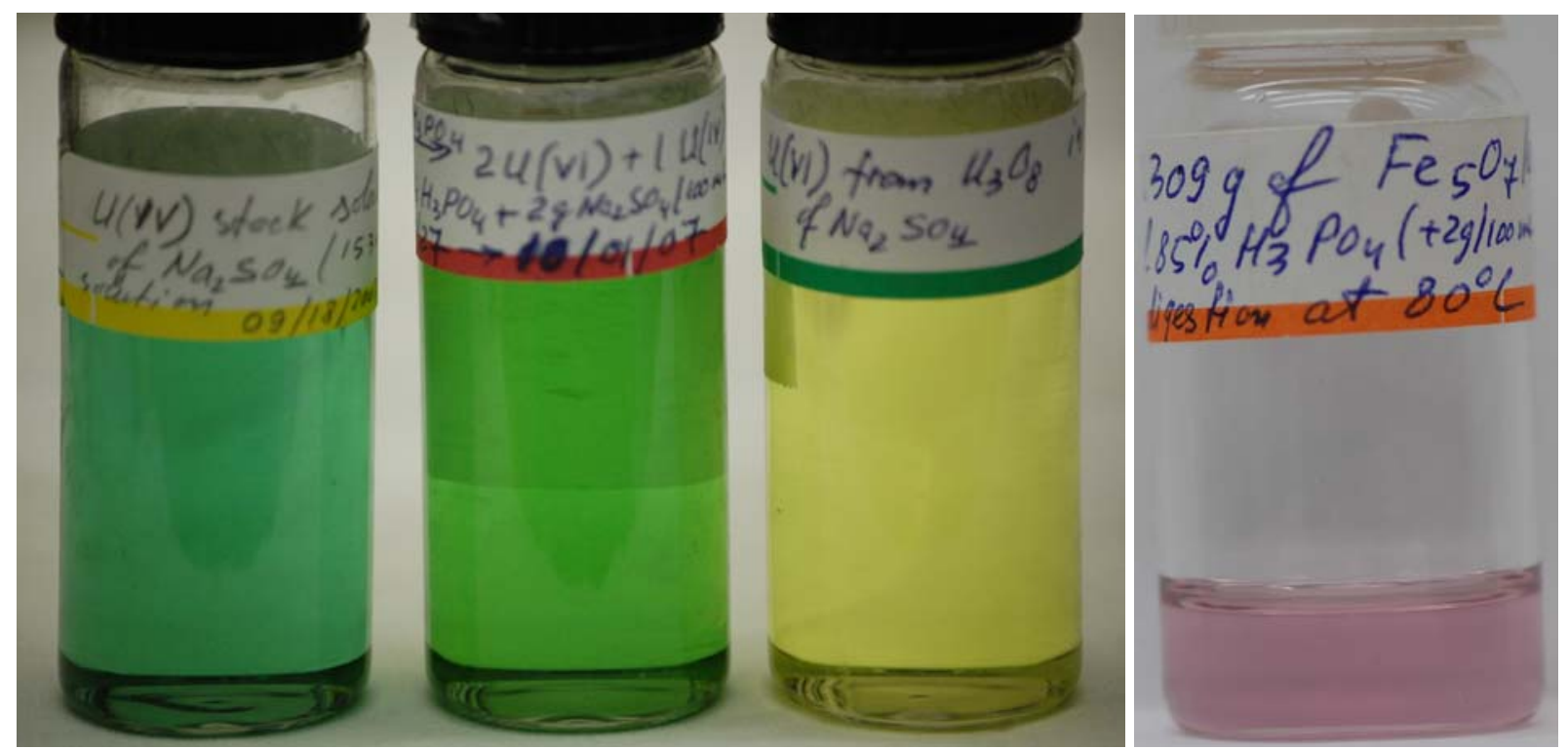

Figure 3.1. Primary Uranium Spectrophotometric Standards, $\mathrm{U}_{3} \mathrm{O}_{8}$ Validation Standard, and $\mathrm{Fe}$ (III) in $\mathrm{Na}_{2} \mathrm{SO}_{4}$-bearing $\mathrm{H}_{3} \mathrm{PO}_{4}$

Left-to-right: $\quad 0.02570 \mathrm{M} \mathrm{U}(\mathrm{IV})$,

$0.07179 \mathrm{M} \mathrm{U}$ in $\mathrm{U}_{3} \mathrm{O}_{8}$,

$0.07208 \mathrm{M} \mathrm{U}(\mathrm{VI})$, and

$0.75 \mathrm{M} \mathrm{Fe}(\mathrm{III})$.

\subsection{Absorbance Measurements of the Spectrophotometric Standards}

Measurements of the various uranium absorbance standards and the Fe(III) solution were made by spectrophotometry in the wavelength range 350 to $950 \mathrm{~nm}$ using tungsten halogen lamp illumination. The SI Photonics 400 spectrophotometer (Tucson, AZ) was used for all measurements. This instrument has a scanning range from 200 to $950 \mathrm{~nm}$ (for both tungsten halogen and deuterium lamps) and 1.17-nm spectral resolution. Plastibrand (Wertheim, Germany) UV-cuvette cells with a 1-cm path length (220- to 950-nm transparency range) were used to collect spectral data. To minimize path length and cell-to-cell variability, the same cuvette was used for all measurements. Absorbance baseline measurements were gathered using $\mathrm{Na}_{2} \mathrm{SO}_{4}$-bearing $\mathrm{H}_{3} \mathrm{PO}_{4}$ solution containing no dissolved uranium or iron. Five to ten scans of the baseline and four to ten scans of each of the uranium-bearing solutions were taken. Ten scans of the Fe(III) solution were gathered. The scans were averaged to minimize random scan-to-scan variability.

Representative U(IV) and U(VI) spectra are shown in Figure 3.2 in terms of molar extinction coefficient, $\varepsilon$, in liters $/$ mole $\cdot \mathrm{cm}$. The spectra were measured using the $1.285 \times 10^{-2} \mathrm{M} \mathrm{U}(\mathrm{IV})$ and $3.604 \times 10^{-2} \mathrm{M} \mathrm{U}(\mathrm{VI})$ 
standards which had peak absorbances of $\sim 0.68$ (at $666 \mathrm{~nm}$ ) and $\sim 0.46$ (at $420 \mathrm{~nm}$ ), respectively. A representative spectrum of $\mathrm{U}_{3} \mathrm{O}_{8}\left(3.590 \times 10^{-2} \mathrm{M}\right.$ total uranium from $\left.\mathrm{U}_{3} \mathrm{O}_{8}\right)$ also is given in Figure 3.2 and is seen qualitatively to be a summation of one U(IV) spectrum and two U(VI) spectra. The $0.75 \mathrm{M} \mathrm{Fe}$ (III) solution spectrum, at a vertical scale ten-times more sensitive than the uranium spectra, is shown as well in Figure 3.2.

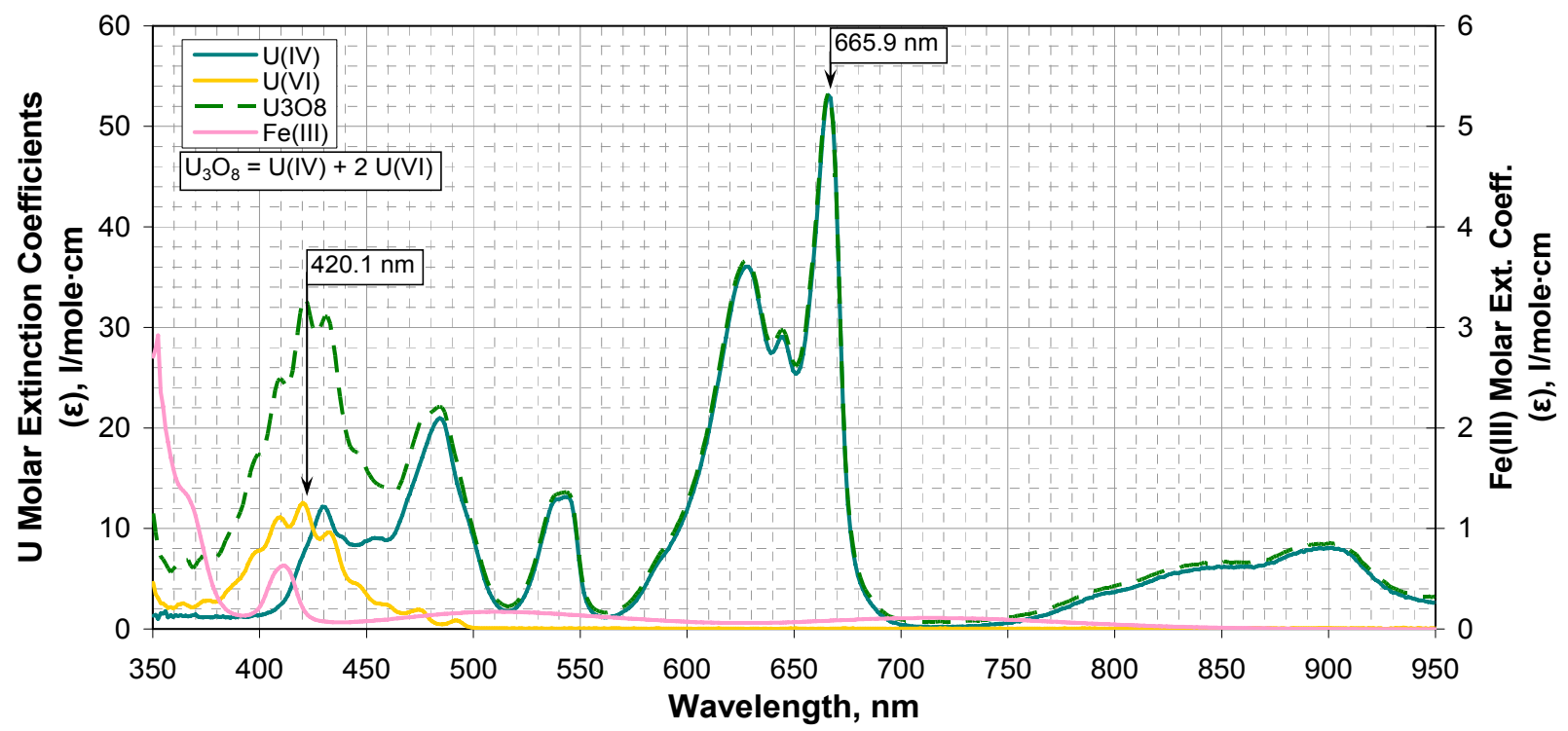

Figure 3.2. Molar Extinction Coefficients of U(IV) and U(VI) Standards and of Fe(III) in $\mathrm{Na}_{2} \mathrm{SO}_{4}-\mathrm{H}_{3} \mathrm{PO}_{4}$

As shown in Figure 3.2, both the U(IV) and U(VI) spectra are highly structured and unique. However, the U(VI) spectrum, whose characteristic features lie between 370 and $500 \mathrm{~nm}$, is not as strong as the U(IV) spectrum and has substantial overlap with it. The greatest U(VI) absorbance with least interfering $\mathrm{U}(\mathrm{IV})$ absorbance, around $405 \mathrm{~nm}$, has molar extinction coefficient, $\varepsilon_{\mathrm{U}(\mathrm{VI})}$, of $\sim 10 \mathrm{l} / \mathrm{mole} \cdot \mathrm{cm}$ (more precise molar extinction coefficient values are presented later in this report). The U(IV) absorbance at $405 \mathrm{~nm}$ is significant compared with that of $\mathrm{U}(\mathrm{VI})$ with $\varepsilon_{\mathrm{U}(\mathrm{IV})} \cong 1.61 / \mathrm{mole} \cdot \mathrm{cm}$. In comparison, the most prominent structures in the U(IV) spectrum, above about $515 \mathrm{~nm}$, suffer relatively little interference from the U(VI) spectrum. The greatest U(IV) absorbance is found at about $666 \mathrm{~nm}$ with a molar absorptivity, $\varepsilon_{\mathrm{U}(\mathrm{IV})}$, of $\sim 53 \mathrm{l} / \mathrm{mole} \cdot \mathrm{cm}$. The U(VI) absorbance at this wavelength is negligible, being $\varepsilon_{\mathrm{U}(\mathrm{VI})} \cong 0.0 \mathrm{l} / \mathrm{mole} \cdot \mathrm{cm}$. Although the contribution of U(VI) to the U(IV) absorbance at $666 \mathrm{~nm}$ is negligible, the contribution of $\mathrm{U}(\mathrm{IV})$ to the $\mathrm{U}(\mathrm{VI})$ spectrum at $405 \mathrm{~nm}$ is significant and must be accounted in determining U(VI) concentration by the Beer-Lambert Law. Selection of optimum wavelengths to determine U(IV) and $\mathrm{U}(\mathrm{VI})$ concentrations is discussed in the following section of the present report.

The Fe(III) spectrum is generally flat but shows increasing absorption as the wavelength decreases towards $350 \mathrm{~nm}$. A small peak, $\varepsilon_{\mathrm{Fe}(\mathrm{III})}=0.63 \mathrm{l} / \mathrm{mole} \cdot \mathrm{cm}$, with maximum absorbance at $410.8 \mathrm{~nm}$, also is observed for $\mathrm{Fe}(\mathrm{III})$. For samples containing low U(VI) concentrations, the presence of significant iron concentrations (e.g., in genuine sludge) will affect accurate determination of U(VI) concentration. For these solutions, further spectral interpretation would be employed taking advantage of the characteristic "hand" shape of the U(VI) spectrum between $\sim 380$ and $450 \mathrm{~nm}$ or, for example, quantifying Fe(III) at $410.8 \mathrm{~nm}$ and $\mathrm{U}(\mathrm{VI})$ at another wavelength away from the Fe(III) peak. No special provision for Fe(III) absorption is required to quantify uranium concentration in the current Fe(III)-free testing with uraninite and metaschoepite. 


\subsubsection{Influence of Water on U(IV) and U(VI) Absorbance Spectra}

The uranium compounds used to prepare the U(IV) and U(VI) absorbance standards, uranium metal and $\mathrm{UO}_{3}$, respectively, contained no water. The mixed $\mathrm{U}(\mathrm{IV}) / \mathrm{U}(\mathrm{VI})$ validation standard, $\mathrm{U}_{3} \mathrm{O}_{8}$, likewise contained no water. However, the uraninite/metaschoepite samples analyzed by spectrophotometry, and the genuine sludge samples that also may be analyzed by this technique, will contain water. The added water in the samples will alter the background $\mathrm{H}_{3} \mathrm{PO}_{4}$ and sulfate concentrations and may affect the appearances of the U(IV) and U(VI) spectra and the respective peak absorbances. The dilution of dissolved sludge by the interstitial sludge water is expected to be $\sim 9$ vol $\%$ under nominal conditions used in the present testing $(\sim 0.5-\mathrm{ml}$ settled sludge volume with $\sim 90 \mathrm{vol} \%$ interstitial water dissolved by $5 \mathrm{ml}$ of the $\mathrm{Na}_{2} \mathrm{SO}_{4}$-bearing $\mathrm{H}_{3} \mathrm{PO}_{4}$ ).

To test the influences of up to 20 volume $\%$ added water, spectra of both U(IV) and U(VI) in $\mathrm{Na}_{2} \mathrm{SO}_{4}$ bearing concentrated $\mathrm{H}_{3} \mathrm{PO}_{4}$ were determined while maintaining, respectively, constant U(IV) or U(VI) concentrations. This was done for the U(VI) experiments by preparation of two secondary stock solutions. The first secondary stock was prepared by diluting 80 volumes of a concentrated U(VI) stock solution in $\mathrm{Na}_{2} \mathrm{SO}_{4}$-bearing $\mathrm{H}_{3} \mathrm{PO}_{4}$ to 100 volume total with $\mathrm{Na}_{2} \mathrm{SO}_{4}$-bearing $\mathrm{H}_{3} \mathrm{PO}_{4}$. The water-diluted secondary stock was prepared by diluting 80 volumes of the same concentrated U(VI) stock solution with 20 volumes of water and mixing. The combined volume was less than 100 in this instance. The combined volume then was adjusted to 100 using $\mathrm{Na}_{2} \mathrm{SO}_{4}$-bearing $\mathrm{H}_{3} \mathrm{PO}_{4}$. The U(VI) concentrations were equal in each secondary stock because the same quantity of concentrated U(VI) stock was diluted to produce the same final total volume.

The concentrated ( $85 \mathrm{wt} \%$ ) $\mathrm{H}_{3} \mathrm{PO}_{4}$ solution density is $1.689 \mathrm{~g} / \mathrm{cm}^{3}$ (Liley et al. 1984); by calculation, the $\mathrm{H}_{3} \mathrm{PO}_{4}$ concentration is $14.65 \mathrm{M}$. By calculation, the solution prepared by diluting 20 volumes of water to 100 total volumes with concentrated $\mathrm{H}_{3} \mathrm{PO}_{4}$ has $1.570 \mathrm{~g} / \mathrm{cm}^{3}$ density and is $11.89 \mathrm{M} \mathrm{H}_{3} \mathrm{PO}_{4}$. The two secondary stocks were combined in stepwise volume ratios of $0: 12,2: 10,4: 8,6: 6,8: 4,10: 2$, and 12:0. By this method, the $\mathrm{H}_{3} \mathrm{PO}_{4}$ concentrations could be varied but the uranium concentrations remain unaltered. Similar secondary stock solutions and mixtures at $0: 12,1: 11,2: 10,3: 9,4: 8,5: 7,6: 6,7: 5,8: 4,9: 3,10: 2$, 11:1, and 12:0 volume ratios were prepared for U(IV).

As shown in Figure 3.3, dilution of the $\mathrm{Na}_{2} \mathrm{SO}_{4}$-bearing $\mathrm{H}_{3} \mathrm{PO}_{4}$ solutions of $\mathrm{U}(\mathrm{VI})$ with up to 20 vol\% water increased the U(VI) peak intensities slightly. Absorbance differences for the seven U(VI) solutions with varying water concentrations were compared in the region $\sim 350-500 \mathrm{~nm}$ by calculating the relative standard deviations of the spectra absorbances over this wavelength range. The differences were lowest, $<0.3 \%$ (relative), around 406 to $411 \mathrm{~nm}$ as the $\mathrm{H}_{3} \mathrm{PO}_{4}$ is diluted by $20 \mathrm{vol} \%$. The optimum measurement wavelength for U(VI) was selected to be $406.2 \mathrm{~nm}$ as it has the lowest interference by U(IV) within the 406 to $411 \mathrm{~nm}$ region of lowest relative standard deviation.

Water dilution has a more pronounced effect on the U(IV) spectrum (Figure 3.4). The most prominent absorbance peak, originally near $665.9 \mathrm{~nm}$ for $\mathrm{Na}_{2} \mathrm{SO}_{4}$-bearing $85 \mathrm{wt} \% \mathrm{H}_{3} \mathrm{PO}_{4}$, shifts to lower absorbance and lower wavelengths with dilution with other prominent peaks (at $\sim 628,543$, and $485 \mathrm{~nm}$ ) similarly shifted. In contrast, the peak at about $644 \mathrm{~nm}$ is little affected by dilution. Isosbestic points (points where absorbances are identical for all spectra and thus unaffected by $\mathrm{H}_{3} \mathrm{PO}_{4}$ concentration) are found at $\sim 662$, $648,640,623,556,535,500$, and $475 \mathrm{~nm}$. These isosbestic points are indicated by minima in the relative standard deviations of the average of the spectra obtained by stepwise water dilution. 


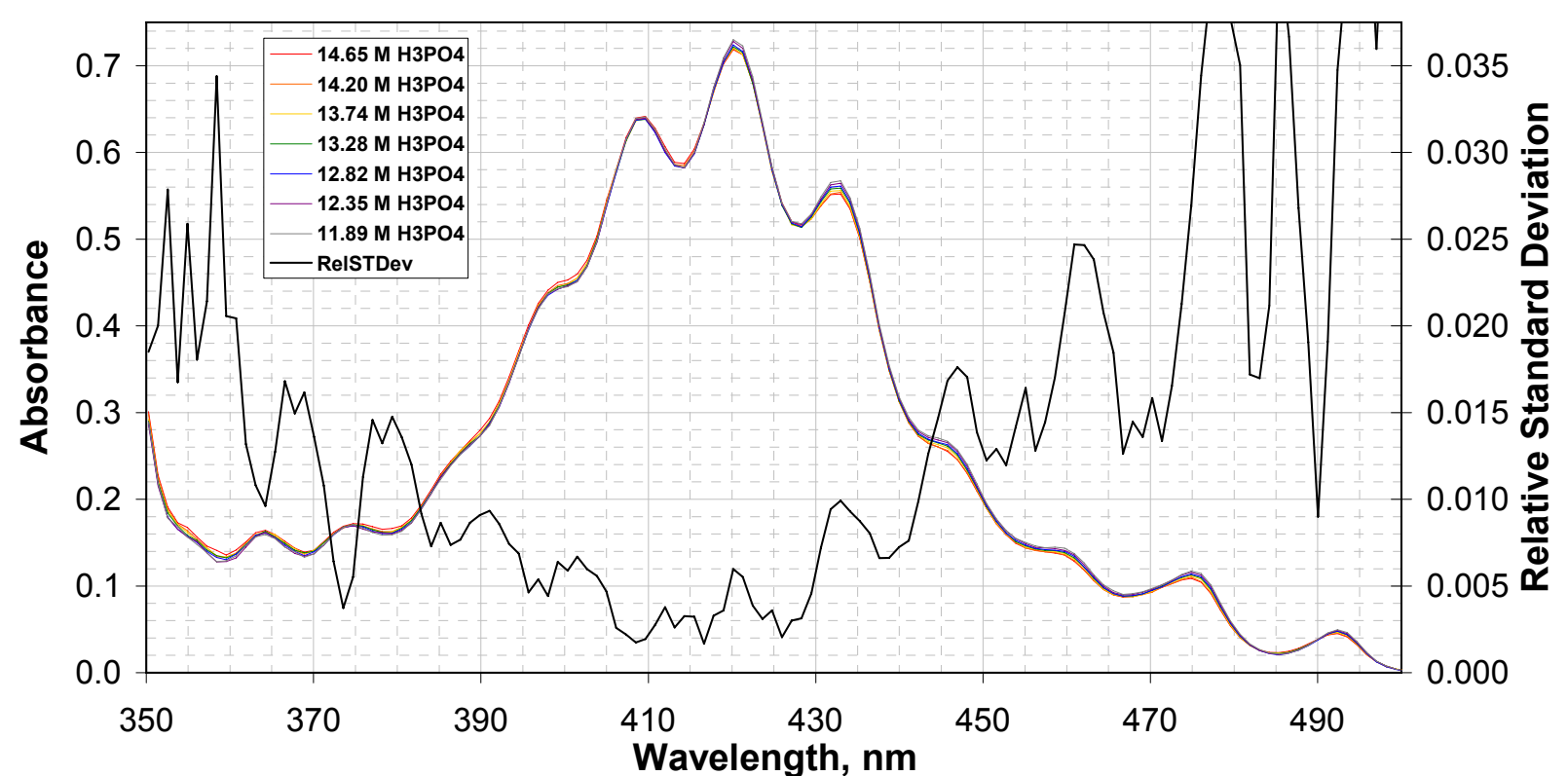

Figure 3.3. Absorbance Measurements of $\mathrm{U}(\mathrm{VI})$ in $\mathrm{Na}_{2} \mathrm{SO}_{4}$-Bearing $\mathrm{H}_{3} \mathrm{PO}_{4}$ at Varying $\mathrm{H}_{3} \mathrm{PO}_{4}$ Concentration

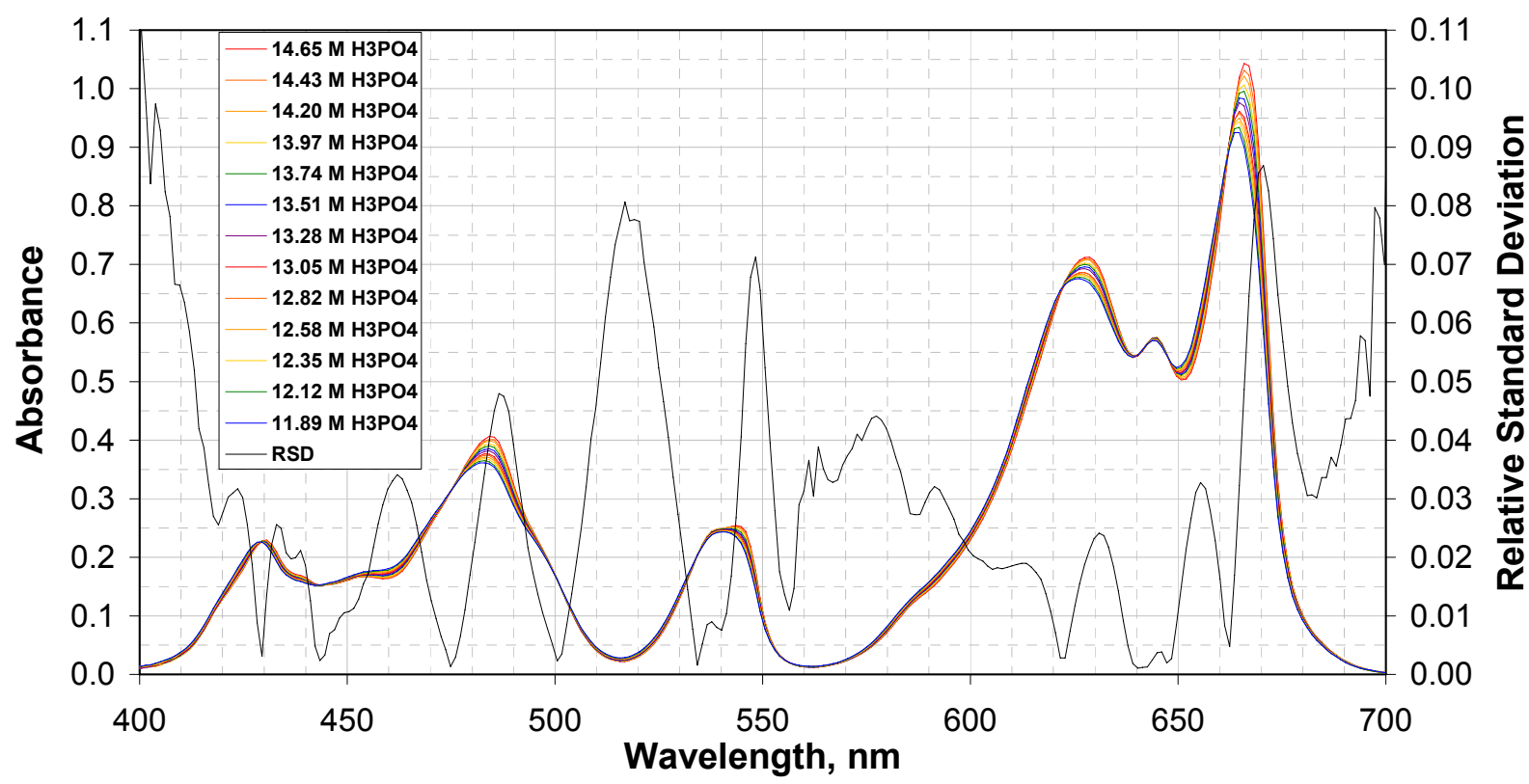

Figure 3.4. Absorbance Measurements of $\mathrm{U}(\mathrm{IV})$ in $\mathrm{Na}_{2} \mathrm{SO}_{4}$-Bearing $\mathrm{H}_{3} \mathrm{PO}_{4}$ at Varying $\mathrm{H}_{3} \mathrm{PO}_{4}$ Concentration

The presence of isosbestic points is consistent with the presence of two absorbing species such as two different U(IV)-hydrogen phosphate complexes. Because of their invariance with changing water or $\mathrm{H}_{3} \mathrm{PO}_{4}$ concentration, these isosbestic points are good wavelengths for monitoring U(IV) concentration in solutions prepared from settled uraninite and metaschoepite solids. The isosbestic point with highest 
absorbance (sensitivity) and suffering lowest relative standard deviation $(\sim 0.13 \%)$ is at $\sim 642.6 \mathrm{~nm}$. This wavelength was selected for quantitation of U(IV) in subsequent measurements of dissolved uraninitemetaschoepite mixtures.

\subsubsection{Influence of Heat, Time, and Light on U(VI) Absorbance Spectra}

The oxidation state stability of $\mathrm{U}(\mathrm{VI})$ in the $\mathrm{Na}_{2} \mathrm{SO}_{4}$-bearing $\mathrm{H}_{3} \mathrm{PO}_{4}$ was called into question based on review of a Los Alamos report describing the decomposition of $\mathrm{U}(\mathrm{VI})$ in concentrated $\mathrm{H}_{3} \mathrm{PO}_{4}$ solution to form U(IV) and oxygen gas (Thamer 1956). As stated on page 13 of that report:

"If a solution of $\mathrm{UO}_{3}$ in concentrated $\mathrm{H}_{3} \mathrm{PO}_{4}$ is heated with an air atmosphere in a closed container, it can be observed that at temperatures of $200^{\circ} \mathrm{C}$. and higher the uranium spontaneously evolves oxygen and is converted to the tetravalent state. The decomposition also is appreciable after a period of several months at room temperature. The decomposition is more rapid and more extensive the higher the phosphoric acid concentration."

Accordingly, the spectra of $3.604 \times 10^{-2} \mathrm{M}$ and $7.208 \times 10^{-2} \mathrm{M} \mathrm{U}(\mathrm{VI})$ solutions were gathered 79 days after their original measurement. The spectra measured at the beginning of this period showed no detectible trace of U(IV) in either solution. The spectrum for $7.208 \times 10^{-2} \mathrm{M} \mathrm{U}(\mathrm{VI})$ solution taken after 79 days showed that $1.1 \%$ of the U(VI) had converted to U(IV); the spectrum of the $3.604 \times 10^{-2} \mathrm{M}$ solution showed $1.85 \%$ conversion. The greater conversion for the more dilute solution may have been because it was stored with more exposure to the continuous fluorescent light in the fume hood holding these samples.

To test this supposition, a separate $7.208 \times 10^{-2} \mathrm{M} \mathrm{U}(\mathrm{VI})$ solution was prepared and stored in the same continuously illuminated fume hood but under a black felt covering. After 56 days, no conversion of $\mathrm{U}(\mathrm{VI})$ to U(IV) was detected. These findings and the observations of the Los Alamos work (Thamer 1956) suggest that concentrated $\mathrm{H}_{3} \mathrm{PO}_{4}$ solution samples of $\mathrm{U}(\mathrm{VI})$ are not stable indefinitely. However, at the low observed photo-induced reduction rates, and as confirmed in the original measurements of the $\mathrm{U}(\mathrm{VI})$ standards, spectrophotometric measurements of U(VI)-bearing solutions made within a few days of sample dissolution in $\mathrm{Na}_{2} \mathrm{SO}_{4}$-bearing $\mathrm{H}_{3} \mathrm{PO}_{4}$ are not significantly altered.

\subsubsection{Beer-Lambert Fit of Calibration Standard Absorbance Spectra}

The molar extinction coefficients of U(IV) and U(VI) standards at the selected quantitation wavelengths of 642.6 and $406.2 \mathrm{~nm}$, respectively, were determined by plotting the absorbance values from multiple spectrophotometric scans (y-axis) against the U(IV) or U(VI) concentrations (x-axis). Given that the path length of the spectrophotometric cell used for these measurements, $b$, is $1.00 \mathrm{~cm}$, according to the BeerLambert Law $(\mathrm{A}=\varepsilon \mathrm{bc})$, the calculated slopes of these plots are the molar extinction coefficients at the relevant wavelengths.

The Beer-Lambert plots of the U(IV) and U(VI) absorbance data are given in Figures 3.5 and 3.6, respectively, and also show the results of the molar extinction coefficient (slope) determinations. The regressions were calculated using average absorbance values determined at 406.2 and $642.6 \mathrm{~nm}$ for each of the five to ten runs of the baseline (zero uranium concentration) solutions and the four to ten runs conducted for each of the seven U(IV)-bearing and five U(VI)-bearing standard solutions. 


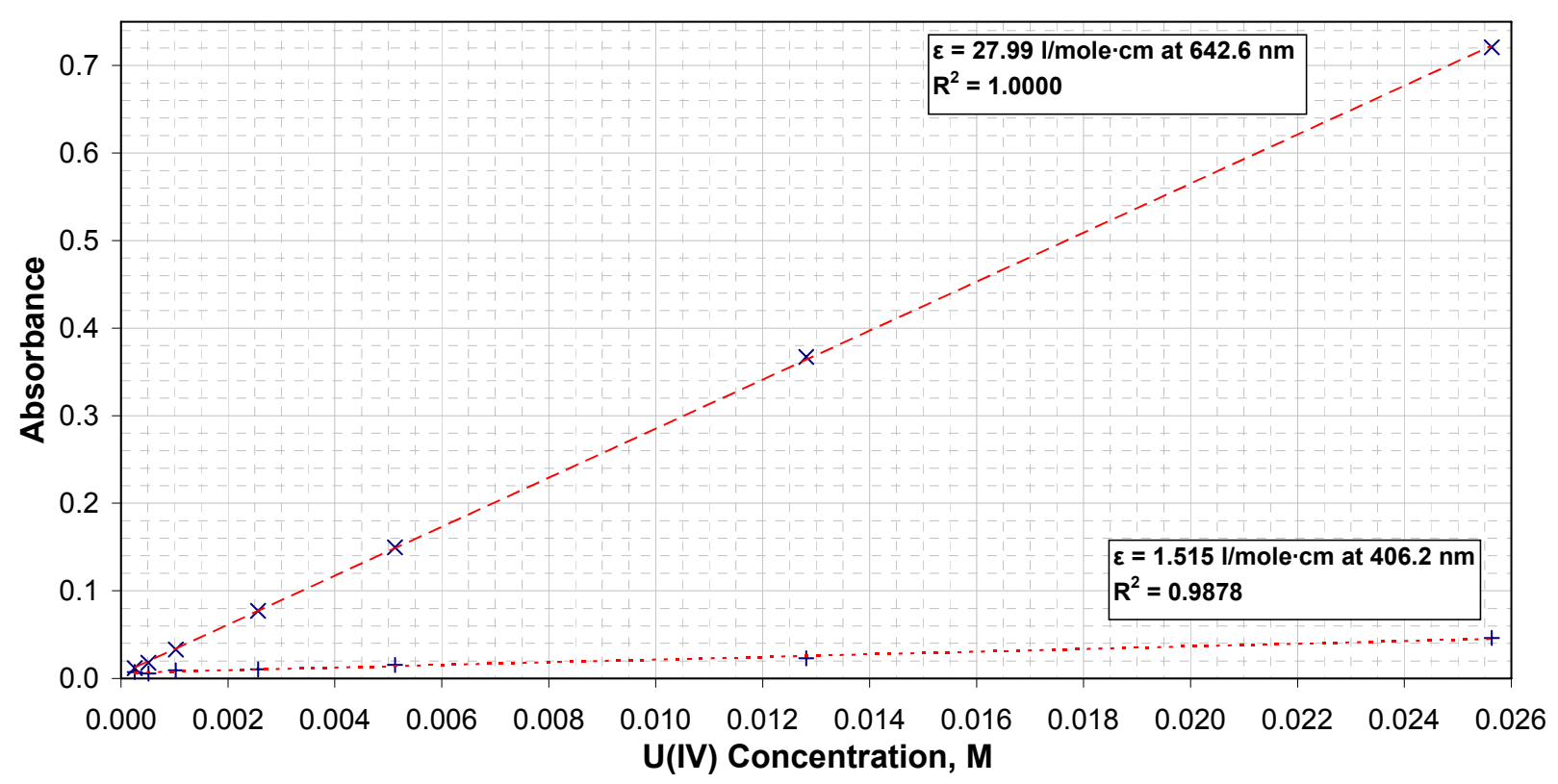

Figure 3.5. Beer-Lambert Determination of Molar Extinction Coefficients for U(IV) at 406.2 and $642.6 \mathrm{~nm}$

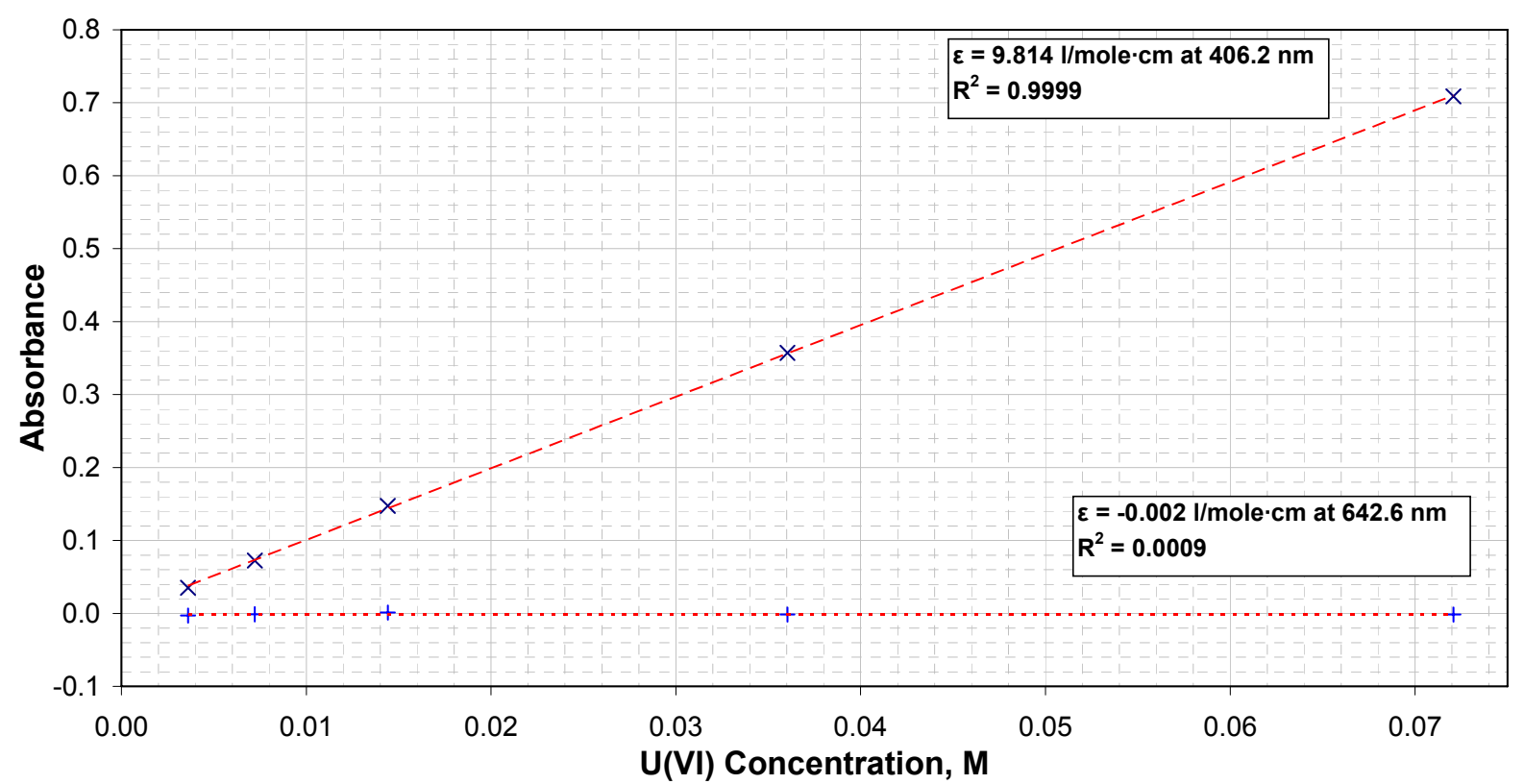

Figure 3.6. Beer-Lambert Determination of Molar Extinction Coefficients for U(VI) at 406.2 and $642.6 \mathrm{~nm}$

The molar extinction coefficients found for U(IV) and U(VI) at 406.2 and $642.6 \mathrm{~nm}$ are presented in Table 3.4. 
PNNL-17678

Table 3.4. Molar Extinction Coefficients for U(IV) and U(VI) Solutions in $\mathrm{Na}_{2} \mathrm{SO}_{4}-\mathrm{H}_{3} \mathrm{PO}_{4}$ Solution

\begin{tabular}{||c|c|c||}
\hline \multirow{2}{*}{ Oxidation State } & \multicolumn{2}{|c|}{ Molar Extinction Coefficient, $\boldsymbol{\varepsilon}$, liter/mole·cm } \\
\cline { 2 - 3 } & $\mathbf{4 0 6 . 2} \mathbf{~ n m}$ & $\mathbf{6 4 2 . 6} \mathbf{~ n m}$ \\
\hline $\mathrm{U}(\mathrm{IV})$ & 1.515 & 27.99 \\
\hline $\mathrm{U}(\mathrm{VI})$ & 9.814 & -0.002 \\
\hline
\end{tabular}

\subsubsection{Application of the Beer-Lambert Law to Determine U(IV) and U(VI) Concentrations}

The concentration of $\mathrm{U}(\mathrm{IV})$ in $\mathrm{Na}_{2} \mathrm{SO}_{4}$-bearing $\mathrm{H}_{3} \mathrm{PO}_{4}$ solution also containing $\mathrm{U}(\mathrm{VI})$ can be determined by measuring the absorbance at $642.6 \mathrm{~nm}$ and then calculating the U(IV) concentration by rearranging the Beer-Lambert Law equation to $\mathrm{c}=\mathrm{A} / \mathrm{b} \varepsilon=\mathrm{A} /(27.99$ liters/mole $)$. As shown in Table 3.4, the contribution of U(VI) to the spectrum at $642.6 \mathrm{~nm}$ is negligible and can be ignored.

However, the contribution of U(IV) to the absorbance at the U(VI) peak maximum at 406.2 is appreciable. To account for the U(IV) contribution, its absorbance at $406.2 \mathrm{~nm}$ must be deducted from the total absorbance measured at $406.2 \mathrm{~nm}$ :

$$
\begin{aligned}
& \mathrm{A}_{\text {total at } 406.2 \mathrm{~nm}}=\mathrm{A}_{\mathrm{U}(\mathrm{IV}) \text { at } 406.2 \mathrm{~nm}}+\mathrm{A}_{\mathrm{U}(\mathrm{VI}) \text { at } 406.2 \mathrm{~nm}} \\
& \mathrm{~A}_{\mathrm{U}(\mathrm{VI}) \text { at } 406.2 \mathrm{~nm}}=\mathrm{A}_{\text {total at } 406.2 \mathrm{~nm}}-\mathrm{A}_{\mathrm{U}(\mathrm{IV}) \text { at } 406.2 \mathrm{~nm}}
\end{aligned}
$$

The concentration of U(IV) in a solution that only contains U(IV) can be determined by absorbance measurements at any wavelength for which significant light absorption occurs. Thus, the concentration could be determined using absorbance measurements at $406.2 \mathrm{~nm}$ as well as at $642.6 \mathrm{~nm}$ :

$$
\mathrm{c}=\frac{\mathrm{A}_{\mathrm{U}(\mathrm{IV}) \text { at } 406.2 \mathrm{~nm}}}{\mathrm{~b} \varepsilon_{\mathrm{U}(\mathrm{IV}) \text { at } 406.2 \mathrm{~nm}}}=\frac{\mathrm{A}_{\mathrm{U}(\mathrm{IV}) \text { at } 642.6 \mathrm{~nm}}}{\mathrm{~b} \varepsilon_{\mathrm{U}(\mathrm{IV}) \text { at } 642.6 \mathrm{~nm}}}
$$

By rearranging this equation, it is seen that the absorbance of U(IV) at $406.2 \mathrm{~nm}$ is proportional to the absorbance of U(IV) at $642.6 \mathrm{~nm}$ with the proportionality given by the ratios of the U(IV) molar extinction coefficients at 406.2 and $642.6 \mathrm{~nm}$, respectively:

$$
\mathrm{A}_{\mathrm{U}(\mathrm{IV}) \text { at } 406.2 \mathrm{~nm}}=\mathrm{A}_{\mathrm{U}(\mathrm{IV}) \text { at } 642.6 \mathrm{~nm}} \times \frac{\varepsilon_{\mathrm{U}(\mathrm{IV}) \text { at } 406.2 \mathrm{~nm}}}{\varepsilon_{\mathrm{U}(\mathrm{IV}) \text { at } 642.6 \mathrm{~nm}}}=\mathrm{A}_{\mathrm{U}(\mathrm{IV}) \text { at } 642.6 \mathrm{~nm}} \times \frac{1.515}{27.99}=0.05413 \times \mathrm{A}_{\mathrm{U}(\mathrm{IV}) \text { at } 642.6 \mathrm{~nm}}
$$

Therefore:

$$
\mathrm{A}_{\mathrm{U}(\mathrm{VI}) \text { at }} 406.2 \mathrm{~nm}=\mathrm{A}_{\text {total at } 406.2 \mathrm{~nm}}-0.05413 \times \mathrm{A}_{\mathrm{U}(\mathrm{IV})} \text { at } 642.6 \mathrm{~nm}
$$

The oxidation state distributions of the absorbance standards prepared directly from $\mathrm{U}_{3} \mathrm{O}_{8}$ (Table 3.3) were determined based on their spectrophotometric measurements and the relevant molar extinction coefficients (Table 3.4). The results of these determinations are shown in Table 3.5. 
Table 3.5. Oxidation State Concentrations and Distributions for $\mathrm{U}_{3} \mathrm{O}_{8}$ Spectrophotometric Standards

\begin{tabular}{|c|c|c|c|c|c|c|c|c|c|}
\hline \multirow{2}{*}{ Standard } & \multirow{2}{*}{$A_{642.6 \mathrm{~nm}}$} & \multirow{2}{*}{$A_{406.2 \mathrm{~nm}}$} & \multicolumn{2}{|c|}{$\mathbf{c}_{\mathrm{U}(\mathrm{IV})}, \mathbf{M}$} & \multirow{2}{*}{$\begin{array}{c}\% \\
\text { rec. }\end{array}$} & \multicolumn{2}{|c|}{$\mathbf{c}_{\mathrm{U}(\mathrm{VI})}, \mathbf{M}$} & \multirow{2}{*}{$\begin{array}{c}\% \\
\text { rec. }\end{array}$} & \multirow{2}{*}{$\begin{array}{l}\mathrm{O} / \mathrm{U} \\
\text { Ratio }\end{array}$} \\
\hline & & & Prepared & Measured & & Prepared & Measured & & \\
\hline $38-\mathrm{S} 1$ & 0.00267 & 0.00448 & 0.000239 & 0.0000955 & 39.9 & 0.000479 & 0.000442 & 92.3 & 2.822 \\
\hline $38-\mathrm{S} 2$ & 0.00951 & 0.00903 & 0.000479 & 0.000340 & 71.0 & 0.000957 & 0.000867 & 90.6 & 2.719 \\
\hline $38-\mathrm{S} 3$ & 28 & 56 & 0.0 & 0.0 & 98.0 & 39 & 0.0 & 101.6 & 2.675 \\
\hline $38-\mathrm{S} 4$ & 0 & 570 & 0.00 & 0.0 & 104.8 & 479 & 0. & 113.2 & 2.684 \\
\hline $38-\mathrm{S} 5$ & 0 & 3 & 79 & 0. & 96.3 & 957 & 77 & 102.1 & 2.679 \\
\hline 38 & & & 0.0 & & 104.6 & & & 105.1 & 2.668 \\
\hline $38-\mathrm{S} 7$ & 0 & 0.524 & 0.0239 & 0.0247 & 103.4 & 0.0479 & 0.0496 & 103.7 & 2.667 \\
\hline \multicolumn{5}{|c|}{ Average (38-S3 to $38-\mathrm{S} 7)$} & 101.4 & & & 105.1 & 2.675 \\
\hline \multicolumn{5}{|c|}{ Standard deviation (38-S3 to $38-\mathrm{S} 7$ ) } & 4.0 & & & 4.7 & 0.007 \\
\hline
\end{tabular}

Several important observations are made from the data shown in Table 3.5. First, the oxygen/uranium $(\mathrm{O} / \mathrm{U})$ mole ratios measured for the seven $\mathrm{U}_{3} \mathrm{O}_{8}$ standards are near the expected value of $8 / 3=2.66 \overline{6}$; i.e., the uranium oxidation state is $5.33 \overline{3}$. The observed $\mathrm{O} / \mathrm{U}$ ratios and oxidation state tend to these values with increasing concentration. This confirms the validity of the present method to determine the $\mathrm{O} / \mathrm{U}$ ratios or average uranium oxidation states in uranium oxide mixtures such as $\mathrm{UO}_{2}$ plus $\mathrm{UO}_{3} \cdot 2 \mathrm{H}_{2} \mathrm{O}$.

The method also is sensitive and able to determine the ratio in $\mathrm{U}_{3} \mathrm{O}_{8}$ accurately to about $0.001 \mathrm{M}$ total uranium. The individual spectrophotometric determinations of U(IV) and U(VI) concentrations are accurate to $\sim 0.001 \mathrm{M}$ for each oxidation state. The lower percent recoveries observed for the 38 -S1 and 38 -S2 standards likely reflect errors in pipeting small volumes of the viscous $\mathrm{H}_{3} \mathrm{PO}_{4}$ solutions. The larger percent recovery divergence between the U(IV) and U(VI) values for the 38-S1 standard likely indicates that the lower limit of the spectrophotometric technique is reached at $\sim 0.01$ absorbance units. 


\subsection{Uraninite Oxidation}

Aqueous slurries of uraninite from MSC were oxidized by ultrapure oxygen gas $\left(99.98 \% \mathrm{O}_{2},<1 \mathrm{ppm}\right.$ $\mathrm{CO}_{2}$; Matheson UHP grade distributed by OXARC) bubbling at ambient lab temperature $\left(\sim 21^{\circ} \mathrm{C}\right)$ and at $50^{\circ} \mathrm{C}$. The oxygen gas was humidified by flowing through a train of two fritted glass water bubblers before it entered the uraninite slurries. The slurries were held in 100-ml polypropylene bottles and were stirred using Teflon-coated magnetic stir bars to ensure efficient mixing and transport of the oxygen to the dense uraninite particles. The excess gas was vented through a $\sim 0.5 \mathrm{~mm}$ inside diameter tube to the air. Each of the slurries was prepared using $50 \mathrm{ml}$ of deionized water and $5 \mathrm{ml}$ of settled uraninite solids in water. This volume of settled uraninite solids (settled density of $2.4 \mathrm{~g} / \mathrm{cm}^{3}$, as will be shown in a succeeding section of this report) weighs 12 grams. At a $\mathrm{UO}_{2}$ particle density of $11 \mathrm{~g} / \mathrm{cm}^{3}$ (Clayton 1961), the volume fraction of water is 0.943 . The uraninite present in each test thus was about 7.3 grams and the total uranium about 0.031 moles.

The oxidation of uraninite, $\mathrm{UO}_{2 . \mathrm{x}}$, by oxygen gas produces metaschoepite, $\mathrm{UO}_{3} \cdot 2 \mathrm{H}_{2} \mathrm{O}$ according to the following reaction stoichiometry:

$$
\mathrm{UO}_{2 . \mathrm{x}}+(0.5-0.5 \times 0 . \mathrm{x}) \mathrm{O}_{2}+2 \mathrm{H}_{2} \mathrm{O} \rightarrow \mathrm{UO}_{3} \cdot 2 \mathrm{H}_{2} \mathrm{O} .
$$

The uraninite is nominally $\mathrm{UO}_{2 . \mathrm{x}}$ where $\mathrm{x}$ lies in the range of 0.0 to 0.25 . The actual uraninite formula of $\mathrm{UO}_{2.004 \pm 0.007}$ was determined by spectrophotometric analysis of the dissolved starting material.

\subsection{Sampling and Analysis}

Eighteen 1-ml samples of the uraninite/metaschoepite suspension were retrieved from each reaction vessel over the 59-day duration of the testing. The sampling was more frequent initially when reaction rates were expected to be most rapid. The samples were collected into 2-dram glass vials and the vials closed. The samples then were analyzed for settled density, $\mathrm{pH}$ of the supernatant solution, and oxidation state of the uranium. The water contents of the uraninite starting material and metaschoepite product in their settled solids were determined. Because uraninite is black and metaschoepite is yellow-green, the progress of the reaction also was monitored visually by photographing the appearance of the sampled slurries. Scanning electron microscopy and XRD further characterized the solid phases.

\subsubsection{Density Determination}

The settled densities were measured by drawing the samples into volume-marked and tare-weighed 1-ml polypropylene syringes. The syringes, partially filled with the slurries, were placed in a point-up position and then allowed to settle. A photograph of some slurry-filled syringes (Figure 4.1) shows that volumes can be read to $0.01 \mathrm{ml}$ precision. After at least one day of settling, the upper solids levels were adjusted to the zero level and the supernatant water collected through the tip using inverted-U shaped $(\cap)$ tubing draining to plastic vials; water between the end of the tip and the top of the solids level was removed by pipet. The supernatant water collected in the vials was retained for $\mathrm{pH}$ measurement. The settled solids volumes were noted and the syringes weighed. The net settled slurry mass was divided by the volume of settled slurry to determine the settled slurry bulk density. 


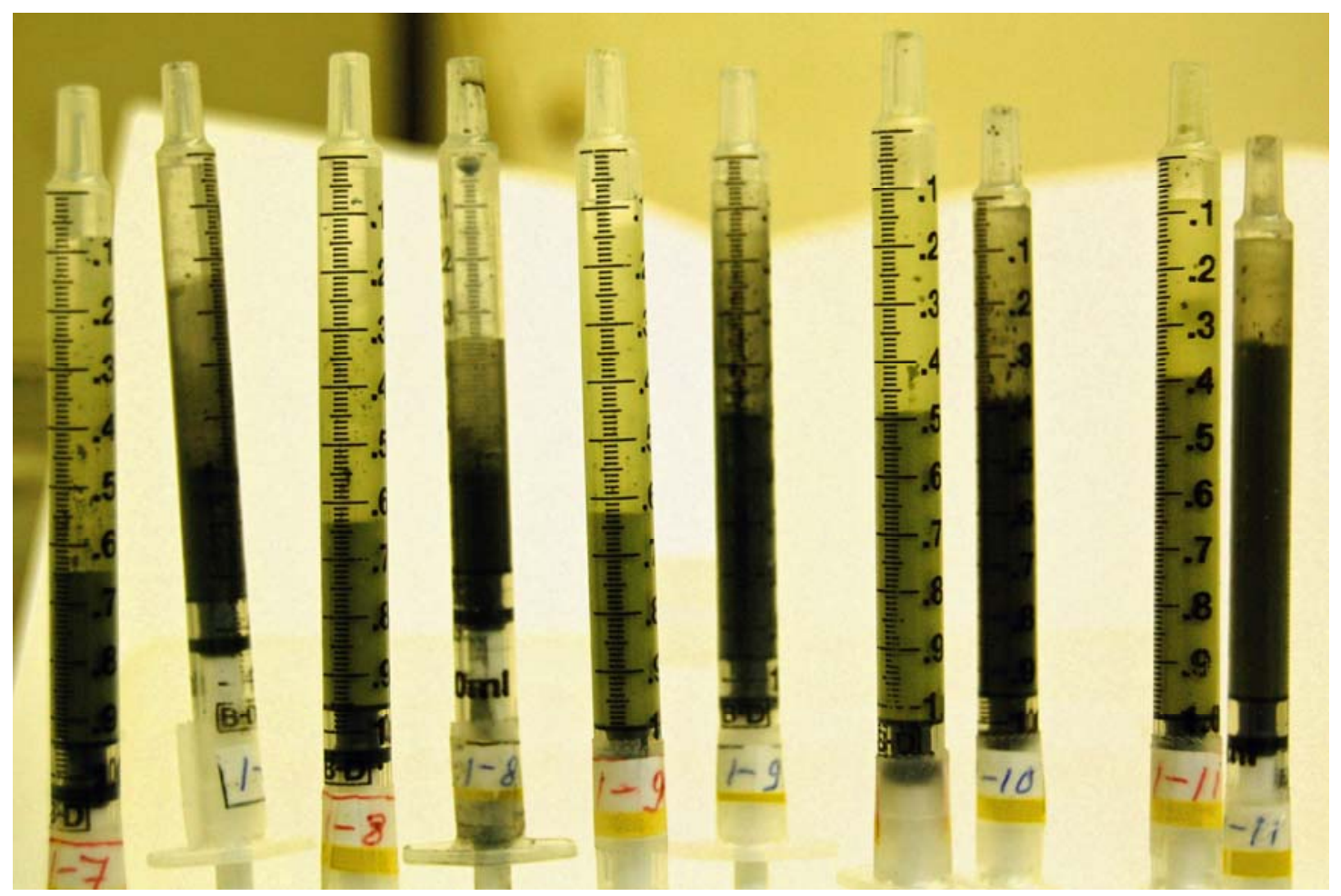

Figure 4.1. Syringe Apparatus Used to Determine Settled Slurry Density Left to right: Samples 7 through 11 at $50^{\circ} \mathrm{C}$ (front) and $21^{\circ} \mathrm{C}$ (back)

Density determinations also were performed for larger samples of the starting uraninite and of the $21^{\circ} \mathrm{C}$ and $50^{\circ} \mathrm{C}$ products obtained after 59 days of oxygen bubbling. For these determinations, tare-weighed and volume-marked 15-ml polypropylene centrifuge cones were used. As will be seen in a later section of the present report, the two methods yielded comparable density values.

The water concentrations of the starting settled uraninite slurry and the product metaschoepite were determined by drying weighed aliquots at $50^{\circ} \mathrm{C}$ and $105^{\circ} \mathrm{C}$. The metaschoepite was heated further to $400^{\circ} \mathrm{C}$ to convert the $\mathrm{UO}_{3} \cdot 2 \mathrm{H}_{2} \mathrm{O}$ to $\mathrm{UO}_{3}$ and thus determine the amount of "hydrate" water (i.e., to verify that the water coefficient is two in the idealized metaschoepite formula of $\mathrm{UO}_{3} \cdot 2 \mathrm{H}_{2} \mathrm{O}$ ).

\subsection{2 pH Measurement}

The $\mathrm{pH}$ values of the supernatant solutions collected from the syringes used for slurry density determinations were measured. For a number of the later samples, the supernatant solution volumes were too low $(<0.2 \mathrm{ml})$ to immerse the $\mathrm{pH}$ probe sufficiently to obtain a $\mathrm{pH}$ value and $\mathrm{pH}$ values were not obtained. However, $\mathrm{pH}$ measurements were made for samples of the supernatant water present at the completion of the $21^{\circ} \mathrm{C}$ and $50^{\circ} \mathrm{C}$ tests.

The $\mathrm{pH}$ measurements were made using a glass electrode calibrated with standard buffer solutions at $\mathrm{pH}$ $4.01,7.00$, and 10.00.

\subsubsection{Uranium Oxidation State Determination}

The U(IV) and U(VI) distribution present in the solids from the sampled slurries were determined using the spectrophotometric technique described in the initial sections of this report. To begin, the settled 
solids collected in the syringes at the completion of the density determinations were discharged into $10 \mathrm{ml}$ of $\mathrm{Na}_{2} \mathrm{SO}_{4}$-bearing $\mathrm{H}_{3} \mathrm{PO}_{4}$. The solids required no more than one hour of heating at about $80^{\circ} \mathrm{C}$ to fully dissolve. Spectrophotometric scans over the range 350 to $950 \mathrm{~nm}$ were collected of the dissolved samples and of a background sample containing only $\mathrm{Na}_{2} \mathrm{SO}_{4}$-bearing $\mathrm{H}_{3} \mathrm{PO}_{4}$ and no dissolved uranium. The same cuvette was used for all spectrophotometric scans (including the standards testing) to minimize errors in path-length variability. At least four scans were made for each sample and five of the background solution. The scans were averaged to minimize random fluctuations and then the absorbance values found at $406.2 \mathrm{~nm}$ and $642.6 \mathrm{~nm}$ determined. The absorbance values were used to calculate the U(IV) and $\mathrm{U}(\mathrm{VI})$ distribution in the solids according to the method described previously.

\subsubsection{Scanning Electron Microscopy}

Samples of the starting, product, and intermediate solids from the uraninite oxidation tests were examined by SEM. The SEM/EDS examinations were performed for air-dried solid slurries that were placed onto conductive carbon tape-covered aluminum SEM examination stubs. The slurries were air-dried and then pressed into the sticky carbon tape to improve electrical contact. The dried samples were carbon-coated. The sample preparation and examination were performed by an established procedure. ${ }^{(a)}$

\subsubsection{X-Ray Diffraction}

The XRD patterns of the starting uraninite and $21^{\circ} \mathrm{C}$ and $50^{\circ} \mathrm{C}$ product solids were gathered to determine what changes in the chemical phases occurred by the oxygen reaction. The starting uraninite was dried under flowing argon (inert gas) conditions to minimize oxidation by atmospheric oxygen. The product solids were dried in air. The mounting of samples for XRD analyses and the collection of XRD scans were performed according to existing laboratory procedures. ${ }^{(b)}$ (c)

\subsection{Uraninite Oxidation Results}

The results of visual observation, SEM and XRD examination, settled density and $\mathrm{pH}$ measurement, and $\mathrm{U}(\mathrm{IV})$ and $\mathrm{U}(\mathrm{VI})$ oxidation state distribution of the uraninite-metaschoepite solids slurries are presented.

\subsubsection{Visual Observations of the Solids}

The progress of the oxidation reaction can be noted qualitatively by the change in color from the black uraninite to the yellow-green metaschoepite. The appearances of the initial eight samples from each test are shown in Figure 4.2. After the $\sim 1$-week span of the first eight samplings, color changes are evident for the $50^{\circ} \mathrm{C}$ test but not for the $21^{\circ} \mathrm{C}$ test.

The appearances of the samples taken from $\sim 2$ to 11 days are shown in Figure 4.3. These edge-on views are better for showing the colors. A marked progression towards the yellow-green color is shown for the $50^{\circ} \mathrm{C}$ tests but the $21^{\circ} \mathrm{C}$ tests show only lightening of the grey tone with no discernable yellow-green color.

(a) MacFarlan, PJ. 2006. Scanning Electron Microscope Examinations, RPL-611A-SEM, Rev. 1, Pacific Northwest National Laboratory, Richland, WA.

(b) Scheele, RD and CH Delegard. 2005. Preparing Sealed Radioactive Samples for XRD and Other Purposes. RPL-PIP-4, Pacific Northwest National Laboratory, Richland, WA.

(c) Schaef, HT. 2004. Operation of Scintag Pad-V X-Ray Diffractometer. RPL-XRD-PIP, Pacific Northwest National Laboratory, Richland, WA. 


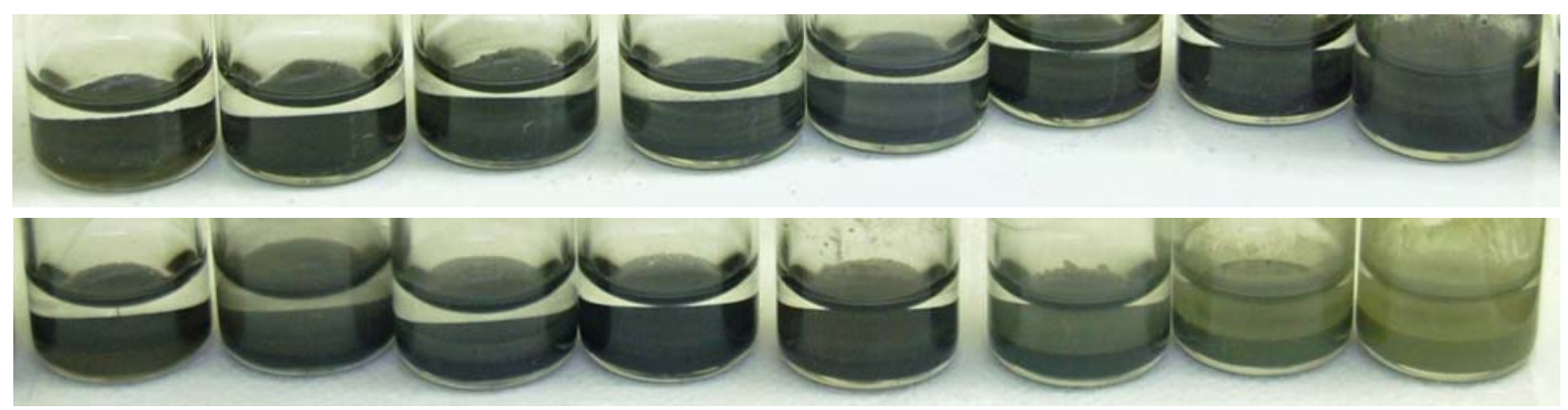

Figure 4.2. Samples from Uraninite Oxidation by Bubbling $\mathrm{O}_{2}$ for 0 to $\sim 7$ Days

Top: $21^{\circ} \mathrm{C}$ products; Bottom: $50^{\circ} \mathrm{C}$ products

Left to right: sample numbers and reaction times:

$\begin{array}{llll}1 & 0.00 \text { days } & 5 & 2.01 \text { days } \\ 2 & 0.19 \text { days } & 6 & 3.17 \text { days } \\ 3 & 0.92 \text { days } & 7 & 4.17 \text { days } \\ 4 & 1.18 \text { days } & 8 & 6.92 \text { days }\end{array}$
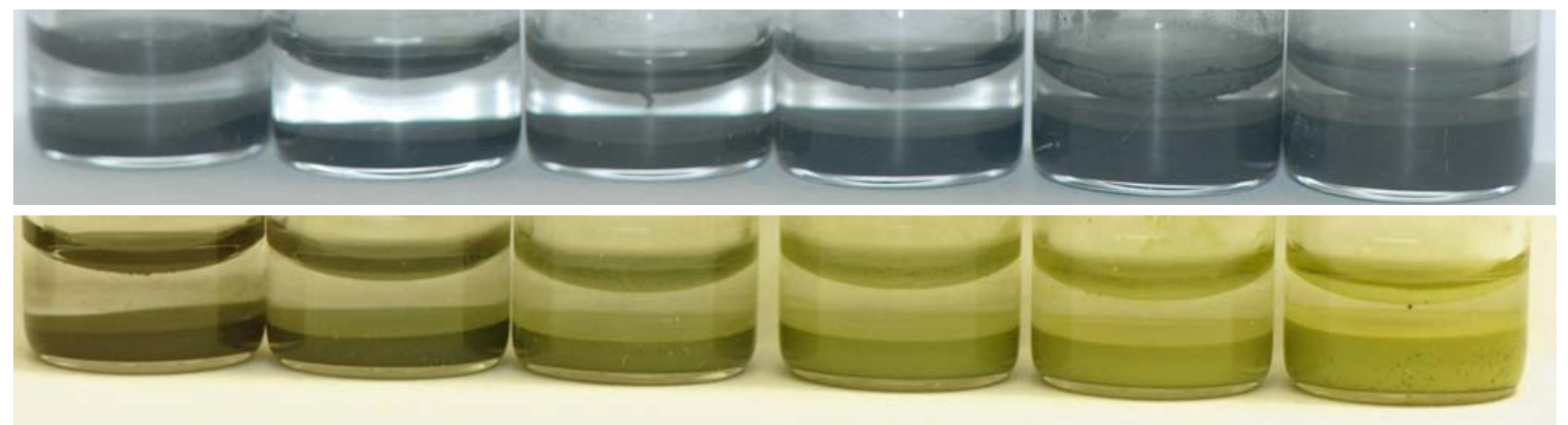

Figure 4.3. Samples from Uraninite Oxidation by Bubbling $\mathrm{O}_{2}$ for $\sim 2$ to 11 Days

Top: $21^{\circ} \mathrm{C}$ products; Bottom: $50^{\circ} \mathrm{C}$ products

Left to right: sample numbers and reaction times:

$\begin{array}{rrrr}5 & 2.01 \text { days } & 8 & 6.92 \text { days } \\ 6 & 3.17 \text { days } & 9 & 8.94 \text { days } \\ 7 & 4.17 \text { days } & 10 & 10.90 \text { days }\end{array}$

A close-up view of the $50^{\circ} \mathrm{C}$ sample 10 (10.90 days) is given in Figure 4.4. Large black particles, very likely of unreacted uraninite and possibly buoyed by abraded polypropylene or Teflon, are clearly visible both in the settled solids and in the water meniscus. The vial diameter is $16 \mathrm{~mm}$; therefore, the large floating speck at the center is about $0.3-\mathrm{mm}$ diameter and the larger black particles in the settled solids are up to $\sim 0.2-\mathrm{mm}$ diameter.

The appearances of the samples taken after 32 to 52 days of reaction are shown in Figure 4.5. By 32 days, the yellow-green color is plainly observed in the $21^{\circ} \mathrm{C}$ product. The yellow-green color lightens with time for both the $21^{\circ} \mathrm{C}$ and $50^{\circ} \mathrm{C}$ sample series. The $50^{\circ} \mathrm{C}$ samples' colors are brighter than the same-aged $21^{\circ} \mathrm{C}$ samples. Black specks also are evident again in a number of the samples both within the settled solids bed and floating on the meniscus. The quantity of black specks generally decreases with time, particularly for the $21^{\circ} \mathrm{C}$ test. These residual black solids almost certainly are unreacted uraninite. 


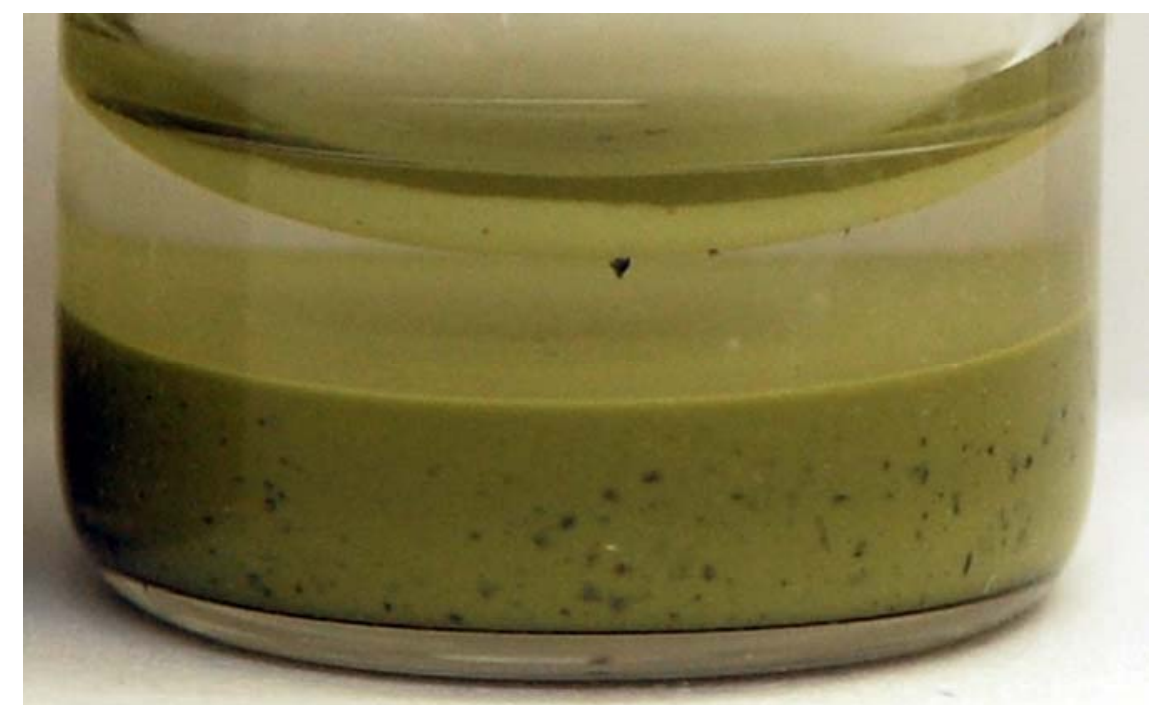

Figure 4.4. Close-up View of 10.90-day Sample from $50^{\circ} \mathrm{C}$ Test (note the black specks, presumably uraninite; some specks are floating)

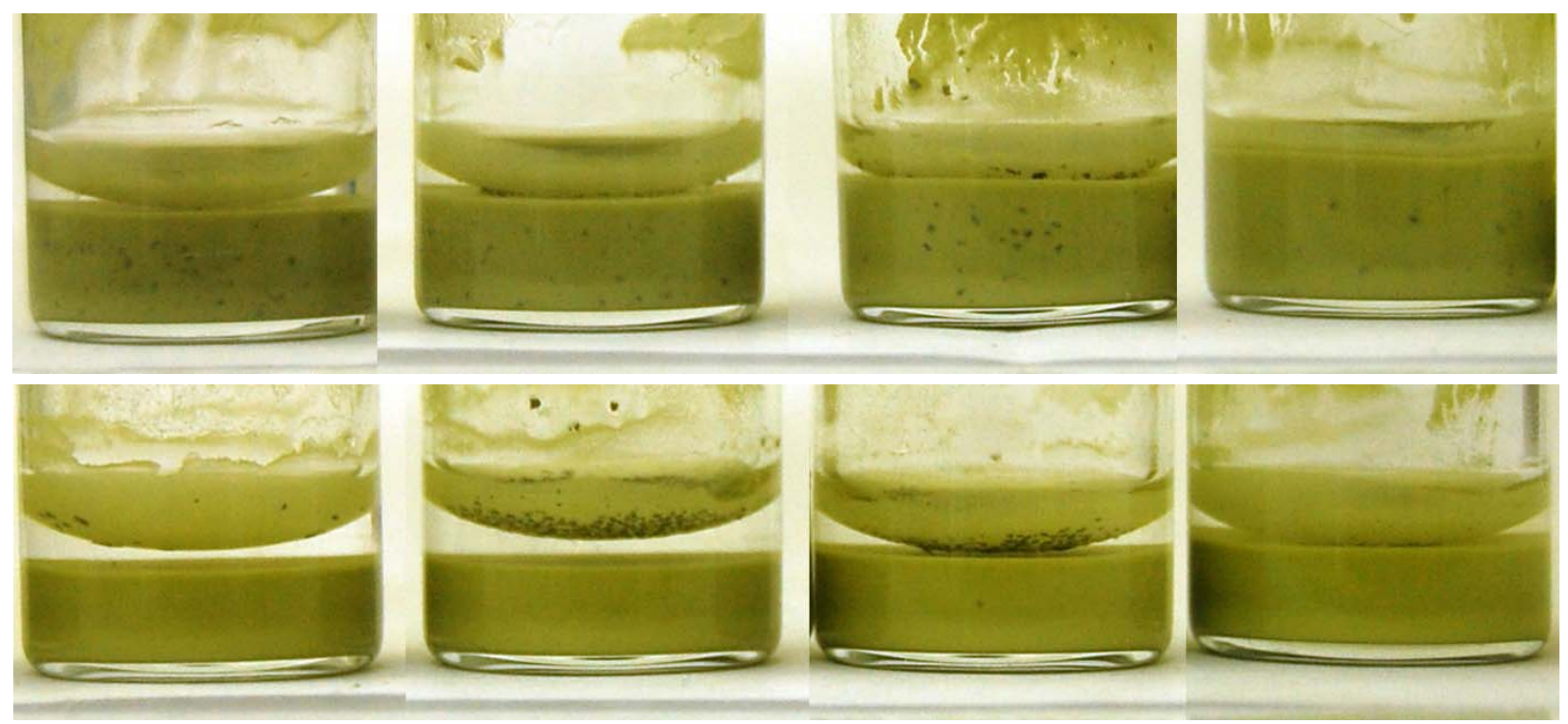

Figure 4.5. Samples from Uraninite Oxidation by Bubbling $\mathrm{O}_{2}$ for $\sim 32$ to 53 Days

Top: at room temperature $\left(\sim 21^{\circ} \mathrm{C}\right)$; Bottom: at $50^{\circ} \mathrm{C}$

Left to right: sample numbers and reaction times:

$$
\begin{array}{llll}
14 & 32.13 \text { days } & 16 & 45.94 \text { days } \\
15 & 36.86 \text { days } & 17 & 52.90 \text { days }
\end{array}
$$

\subsubsection{X-Ray Diffractometry}

The initial uraninite and the oxidation products obtained after 59 days of oxygen gas bubbling at $21^{\circ} \mathrm{C}$ and $50^{\circ} \mathrm{C}$ were examined by XRD to verify the expected uraninite starting material and metaschoepite product. The metaschoepite products were found to provide XRD scans very similar to the scan observed for sludge $\mathrm{KC}-2 / 3 \mathrm{M} 250$, a uranium-rich canister sludge passing a $250 \mu \mathrm{m}$ screen that had been archived 
for eight years after its March-April 1999 retrieval under warm $\left(\sim 25-35^{\circ} \mathrm{C}\right)$, moist, and oxidizing hot cell conditions (Delegard et al. 2007a). ${ }^{\text {(a) }}$

The diffraction scans of the initial uraninite, the $21^{\circ} \mathrm{C}$ and $50^{\circ} \mathrm{C}$ metaschoepite products, and the KC-2/3 M250 sludge are compared in Figure 4.6. The scans have been offset by multiples of 5000 CPS (counts per second) to allow comparison. In addition, for the starting uraninite scan, the vertical axis was enhanced 8-fold to show detail in these broad peaks. The KC-2/3 M250 scan was magnified 5 fold.

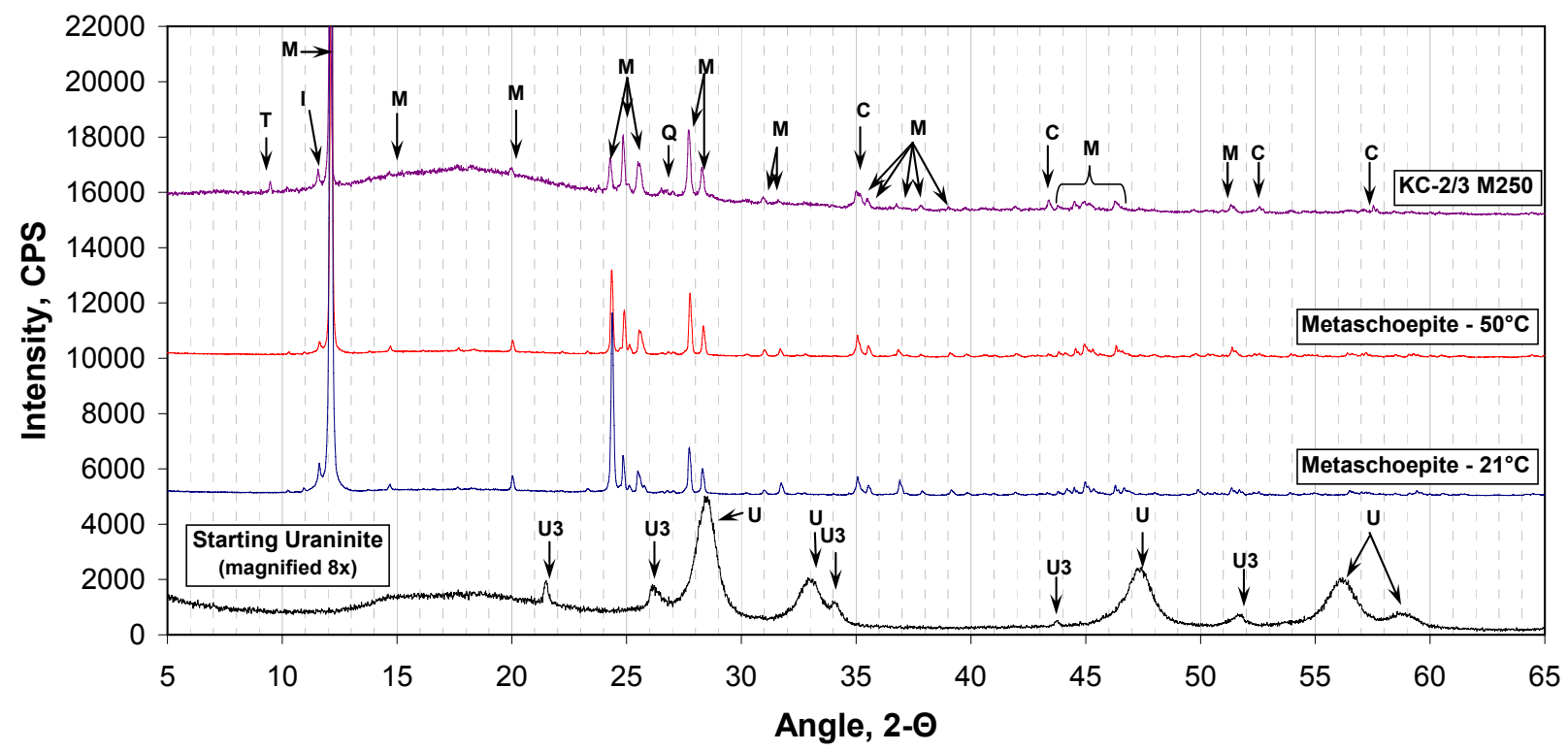

Figure 4.6. X-Ray Diffraction Patterns for Starting Uraninite, $21^{\circ} \mathrm{C}$ and $50^{\circ} \mathrm{C}$ Product Metaschoepite, and Aged K East Basin Sludge KC-2/3 M250

\begin{tabular}{|ll|}
\hline $\mathrm{C}=$ corundum, $\mathrm{Al}_{2} \mathrm{O}_{3}$, internal standard & $\mathrm{T}=$ talc, glove powder contaminant \\
$\mathrm{I}=$ ianthinite, $\mathrm{U}_{2}\left(\mathrm{UO}_{2}\right)_{4} \mathrm{O}_{6}(\mathrm{OH})_{4}\left(\mathrm{H}_{2} \mathrm{O}\right)_{4} \cdot 5 \mathrm{H}_{2} \mathrm{O}$ & $\mathrm{U}=$ uraninite, $\mathrm{UO}_{2}, \mathrm{U}_{3} \mathrm{O}_{7}($ minor $)$ \\
$\mathrm{Q}=$ quartz, $\mathrm{SiO}_{2}$ & $\mathrm{U} 3=$ uranium octaoxide, $\mathrm{U}_{3} \mathrm{O}_{8}$ \\
$\mathrm{M}=$ metaschoepite, $\mathrm{UO}_{3} \cdot 2 \mathrm{H}_{2} \mathrm{O}$ & \\
\hline
\end{tabular}

Despite the care taken in preparing the XRD mount for the starting $\mathrm{UO}_{2}$ (i.e., drying under argon, coating with Krylon), small ( $\sim 10 \%$ ) concentrations of more-oxidized uranium compounds $\mathrm{U}_{3} \mathrm{O}_{7}$ and $\mathrm{U}_{3} \mathrm{O}_{8}$ were observed. The uraninite diffraction peaks were broad, indicating that the uraninite particles are small. Based on the breadth of the XRD pattern peaks and by use of the Scherrer equation, the individual $\mathrm{UO}_{2}$ crystallite particle size is estimated to be $\sim 6 \mathrm{~nm}$. In the Scherrer equation:

$$
\mathrm{L}=\frac{\mathrm{K} \lambda}{\mathrm{B}_{1 / 2} \cos \Theta_{\mathrm{B}}}
$$

where $\mathrm{L}$ is the crystallite particle size, $\mathrm{K}$ is a geometrical constant ranging between 0.85 and 0.99 ( 0.9 is typically used), $\lambda$ is the wavelength of the $\mathrm{X}$-ray being used $\left(0.154056 \mathrm{~nm}\right.$ for the copper $\mathrm{K}_{\alpha} \mathrm{X}$-ray in the

(a) The KC-2/3 M250 sludge is a composite collected from 11 fuel storage canister locations in the KE Basin. The KC-2/3 sample (all particulate material less than $1 / 4$-inch, $6350 \mu \mathrm{m}$ ) was sieved in 1999 at $250 \mu \mathrm{m}$ to provide a "plus (P250)" and "minus (M250)" fraction. The KC-2/3 M250 sludge is $68.3 \mathrm{wt} \%$ uranium on a dry weight basis. 
present technique), $\mathrm{B}_{\frac{1}{2}}$ is the full width at half maximum, in radians, for the diffraction peak of interest, and $\Theta_{\mathrm{B}}$ is the Bragg angle of the diffraction peak of interest.

The XRD patterns for the $21^{\circ} \mathrm{C}$ and $50^{\circ} \mathrm{C}$ products were found to be strikingly similar to each other and to the metaschoepite pattern found in February 2007 by XRD of $\mathrm{K}$ Basin sludge sample KC-2/3 M250 (Delegard et al. 2007a). Small amounts of quartz, $\mathrm{SiO}_{2}$, and ianthinite $\left[\mathrm{U}_{2}\left(\mathrm{UO}_{2}\right)_{4} \mathrm{O}_{6}(\mathrm{OH})_{4}\left(\mathrm{H}_{2} \mathrm{O}\right)_{4} \cdot 5 \mathrm{H}_{2} \mathrm{O}\right.$; with average uranium oxidation state of 5.33 $\overline{3}$ ] also were found in the aged $\mathrm{KC}-2 / 3 \mathrm{M} 250$ sample with the corundum $\left(\mathrm{Al}_{2} \mathrm{O}_{3}\right)$ internal standard and a trace talc impurity from radiological glove powder also appearing. As was true for KC-2/3 M250, metaschoepite was the dominant phase found in the $21^{\circ} \mathrm{C}$ and $50^{\circ} \mathrm{C}$ products of uraninite oxidation accompanied in both cases by a small amounts $(\sim 2 \%)$ of ianthinite based on the relative intensity ratios of the ianthinite and metaschoepite peaks. The presence of ianthinite indicates that the oxidation of uraninite by oxygen gas to form U(VI) (metaschoepite) was incomplete. With the presence of $2 \%$ ianthinite and presuming that the entire balance was metaschoepite, $99.3 \%$ conversion of U(IV) to U(VI) occurred.

Prior analyses of KC-2/3 M250 showed that it contains $68 \mathrm{wt} \%$ uranium on a dry $\left(105^{\circ} \mathrm{C}\right)$ basis. Metaschoepite is $78.3 \mathrm{wt} \%$ uranium when dried under similar $105^{\circ} \mathrm{C}$ conditions. The $\mathrm{KC}-2 / 3 \mathrm{M} 250$ sample also contained little uranium metal when analyzed by gas generation testing in the interval October 1999 - June 2000 ( $\sim 0.2 \mathrm{wt} \%$ by fission product gas release; Bryan et al. 2004). That trace amount of uranium metal very likely has been completely oxidized in the intervening years. Overall, these gravimetric and $\mathrm{XRD}$ data indicate that the $\mathrm{KC}-2 / 3 \mathrm{M} 250$ sample is overwhelmingly metaschoepite and that close correspondence exists between the KC-2/3 M250 sample and the metaschoepite produced by uraninite oxidation by oxygen gas in the present testing.

Metaschoepite is known to undergo irreversible dehydration (to dehydrated schoepite; e.g., $\mathrm{UO}_{3} \cdot 0.8 \mathrm{H}_{2} \mathrm{O}$ ) when heated in $105^{\circ} \mathrm{C}$ air (Finch et al. 1998; Sowder et al. 1999) or, when present in K Basin sludge $\mathrm{KC}-2 / 3 \mathrm{M} 250$, is heated hydrothermally at $185^{\circ} \mathrm{C}$ (Delegard et al. 2007a). However, the dehydration reportedly does not occur below $65^{\circ} \mathrm{C}$ in heated water or air (Finch et al. 1998 and Sowder et al. 1999, respectively). The present testing, which shows nearly identical metaschoepite XRD patterns for both $21^{\circ} \mathrm{C}$ and $50^{\circ} \mathrm{C}$ uraninite oxidation products, confirms the findings in the published literature and indicates that metaschoepite can be synthesized at either room temperature or at $50^{\circ} \mathrm{C}$ with no appearance of dehydrated schoepite.

\subsubsection{Scanning Electron Microscopy}

Samples of the starting uraninite, product metaschoepite, and intermediate solids obtained after about $1 / 3$ and $2 / 3$ conversions for both test temperatures were examined by SEM. The examinations were performed to depict the appearances of the particles and to discern if differences in product metaschoepite particle shape or size occurred as a result of temperature. These images also were compared with those of genuine sludge $\mathrm{KC}-2 / 3 \mathrm{M} 250$ available in hot cell storage. The images from the $21^{\circ} \mathrm{C}$ tests are shown in Figure 4.7 and the images from the $50^{\circ} \mathrm{C}$ tests in Figure 4.8. The starting (uraninite) material image is the same for both temperatures; the magnification, as printed on $8 \frac{1}{2} \times 11$-inch paper, is about $725 \times$ for all images.

The smallest discernable particle size is approximately $0.1 \mu \mathrm{m}(100 \mathrm{~nm})$ in the starting uraninite materials depicted in the upper left corners of Figures 4.7 and 4.8. Larger irregularly shaped flakes also are evident. These flakes likely arose due to the method used to prepare the sample (air-drying onto a carbon tapecovered aluminum stub). It is seen that as the reactions with dissolved oxygen gas proceeded, crystals with more regular shapes (straight edges, distinct angles) appear and the relative amounts of irregular 

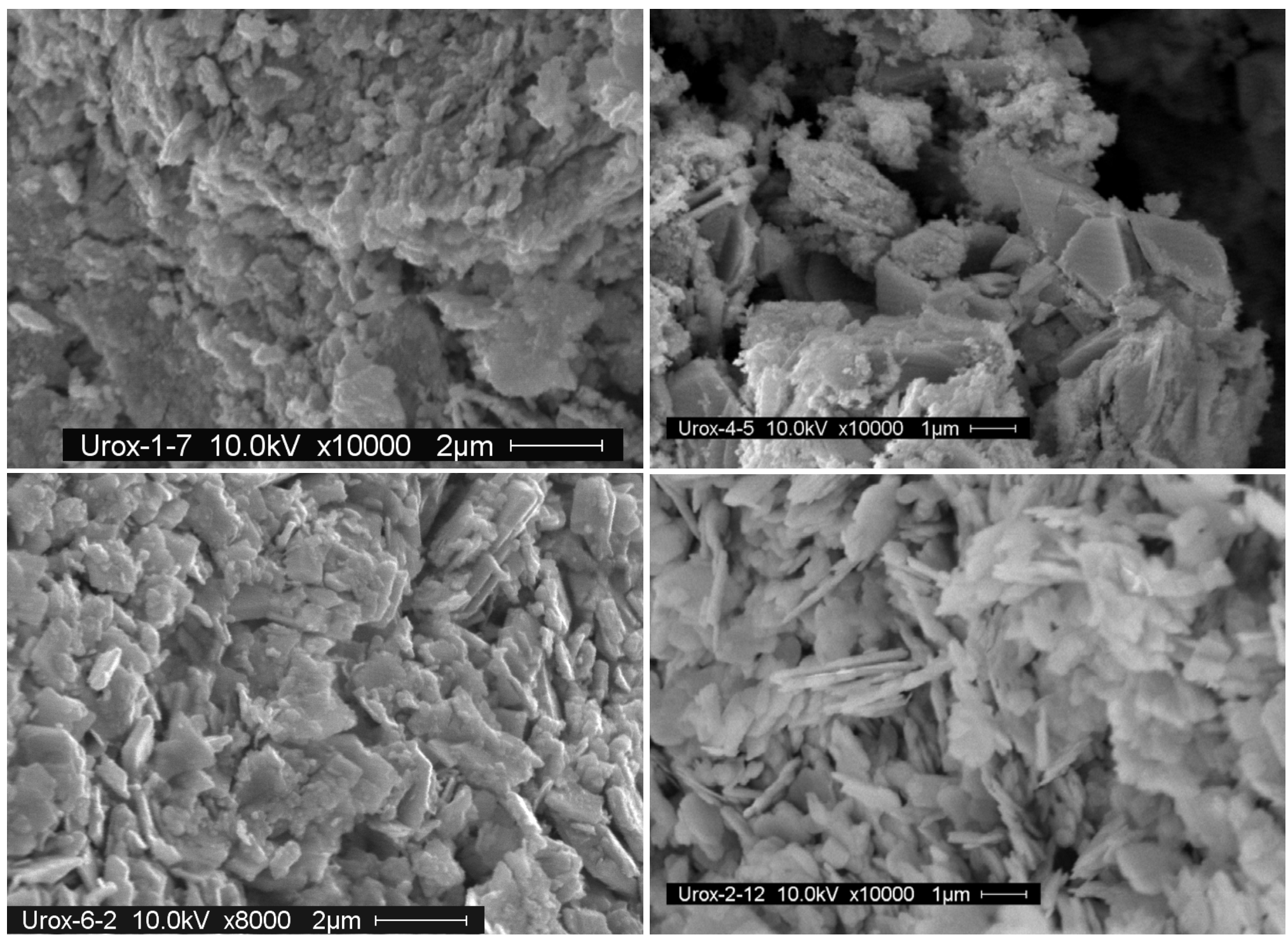

Figure 4.7. SEM Images of $21^{\circ} \mathrm{C}$ Test Materials (magnification of all images on page $\sim 725 \times$ )

Top left to bottom right: Starting Uraninite, 1/3 Reaction (sample 3), 2/3 Reaction (sample 8), and Near Complete Reaction (sample 18) 


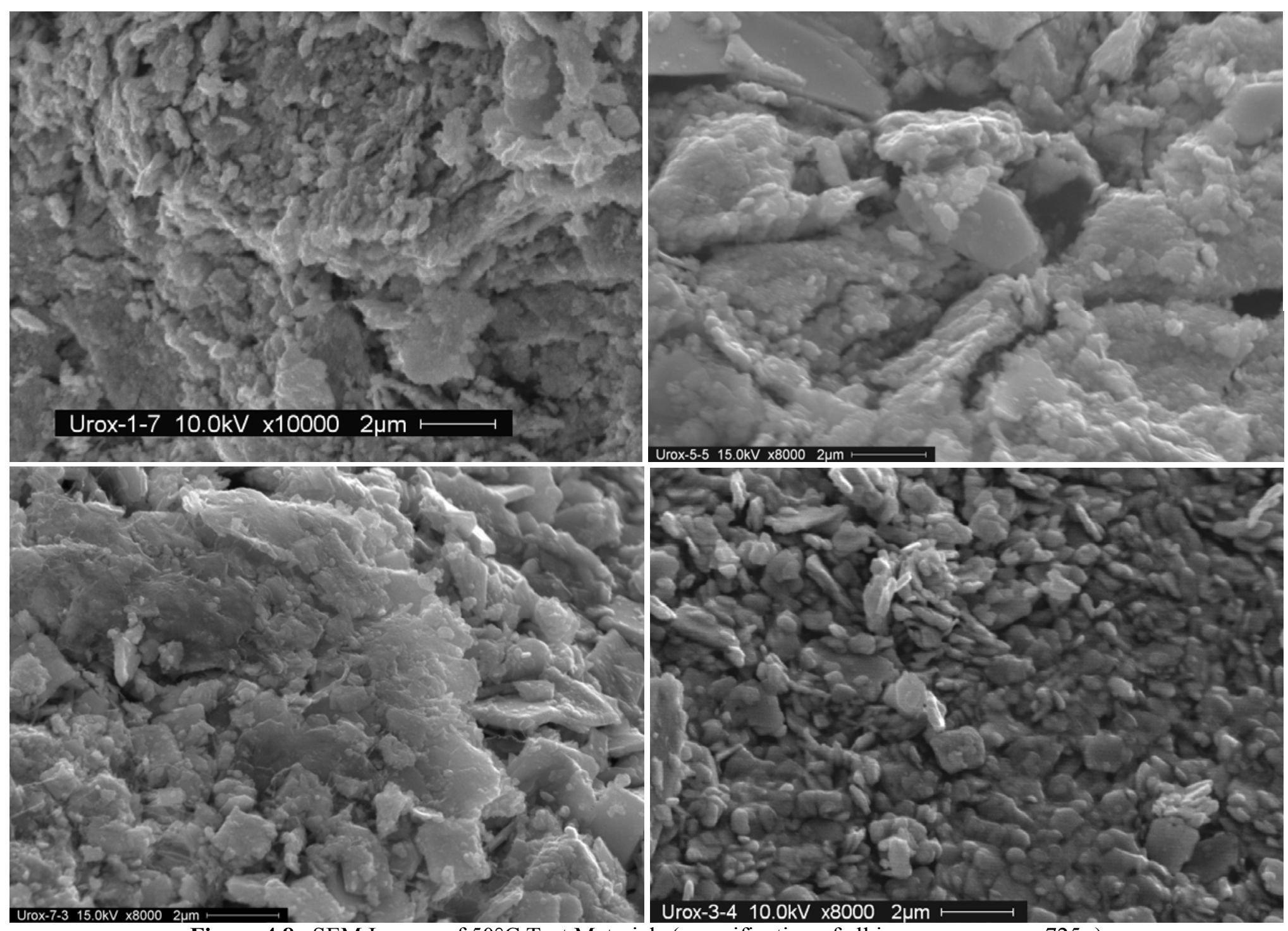

Figure 4.8. SEM Images of $50^{\circ} \mathrm{C}$ Test Materials (magnification of all images on page $\sim 725 \times$ )

Top left to bottom right: Starting Uraninite, 1/3 Reaction (sample 2), 2/3 Reaction (sample 5), and Near Full Reaction (sample 18) 
shapes diminish. At the completion of the $21^{\circ} \mathrm{C}$ oxidation test, the crystals attain a snowflake appearance, with thin hexagonal shape (see lower right image in Figure 4.7). The metaschoepite product crystals from the $50^{\circ} \mathrm{C}$ tests are thicker and are more rounded than the $21^{\circ} \mathrm{C}$ product crystals.

As noted in the prior section, metaschoepite was the principal phase identified in February 2007 by XRD in aged $\mathrm{K}$ Basin sludge sample $\mathrm{KC}-2 / 3 \mathrm{M} 250$ (Delegard et al. 2007a). The appearances of the $21^{\circ} \mathrm{C}$ and $50^{\circ} \mathrm{C}$ metaschoepite products are compared with the appearance of the $\mathrm{KC}-2 / 3 \mathrm{M} 250$ sludge in Figure 4.9. The magnifications for these images are equal and about $270 \times$.

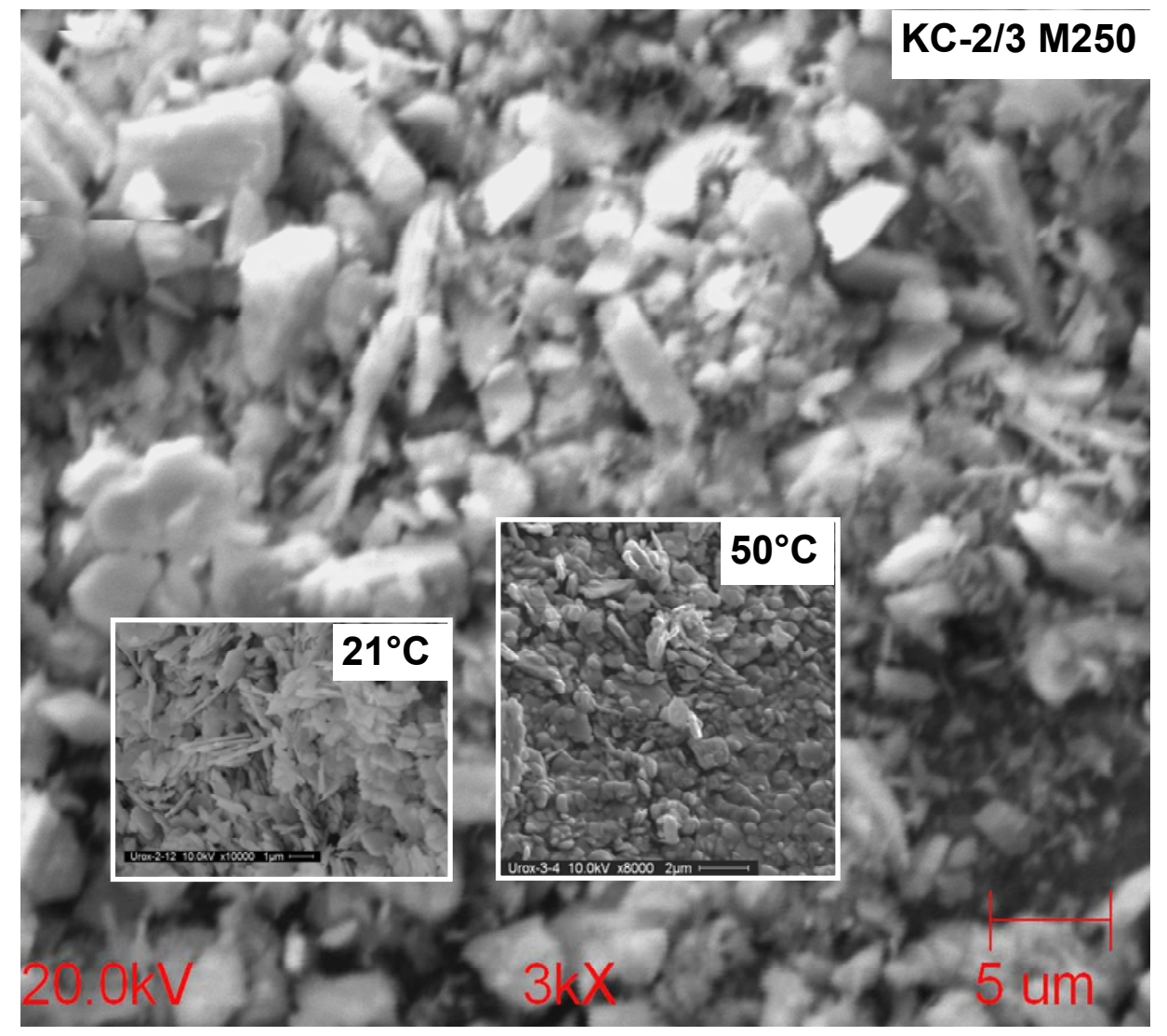

Figure 4.9. SEM Images of $\mathrm{KC}-2 / 3 \mathrm{M} 250$ Sludge and $21^{\circ} \mathrm{C}$ and $50^{\circ} \mathrm{C}$ Metaschoepite Products (magnification of all images on page $\sim 270 \times$ )

It is seen that, although some smaller particles are observed, many of the metaschoepite particles in the aged KC-2/3 M250 sludge are much larger and thicker than the particles obtained in either the $21^{\circ} \mathrm{C}$ or $50^{\circ} \mathrm{C}$ metaschoepite products. Though some particle breakage may have occurred in the metaschoepite synthesis, extended hot cell storage time likely led to growth of larger particles in the KC-2/3 M250 sludge. The $\mathrm{KC}-2 / 3 \mathrm{M} 250$ sludge stored at the $\sim 32^{\circ} \mathrm{C}$ oxic conditions in the hot cell may not represent sludge present in the cooler $\left(\sim 10-15^{\circ} \mathrm{C}\right) \mathrm{K}$ Basins.

Although particle size analyses of sludge have been performed during characterization testing (Makenas et al. 1996, 1997, and 1998), the size of metaschoepite particles in genuine sludge, as opposed to the ensemble particle size from the various sludge phases, is not known. However, the number-basis particle size distributions of the uranium-rich KE Basin canister sludge 96-06 ( $\sim 84 \mathrm{wt} \% \mathrm{U}$, dry basis) range from 
about 0.4 to $3 \mu \mathrm{m}$ and are near those observed in the uraninite and the $50^{\circ} \mathrm{C}$ test product material (which are $\sim 88$ and $78 \mathrm{wt} \% \mathrm{U}$, dry basis, respectively). The number-basis particle size distributions measured for other sludges having lower uranium concentrations also are in the $\sim 0.2$ to $5 \mu \mathrm{m}$ range.

\subsubsection{Settled Uranium Oxide Density Results}

The densities of the settled samples are presented as functions of reaction time in Table 4.1 and plotted in Figure 4.10. It is seen that the density decreases for both $21^{\circ} \mathrm{C}$ and $50^{\circ} \mathrm{C}$ most rapidly at early reaction times and are near their final values $\left(\sim 1.2 \mathrm{~g} / \mathrm{cm}^{3}\right)$ after about two weeks. However, both test series show slightly increasing density at the end of testing at 59 days. The final density of the $50^{\circ} \mathrm{C}$ product is moderately higher than that of the $21^{\circ} \mathrm{C}$ product.

Table 4.1. Settled Solids Densities for Uraninite-Metaschoepite Mixtures

\begin{tabular}{|c|c|c|c|c|c|}
\hline \multirow{2}{*}{ Sample } & \multirow{2}{*}{\begin{tabular}{|c|} 
Reaction \\
Time, days
\end{tabular}} & \multicolumn{2}{|c|}{ Density, $\mathrm{g} / \mathrm{cm}^{3}$} & \multicolumn{2}{|c|}{ Volume Fraction $\mathrm{H}_{2} \mathrm{O}$} \\
\hline & & $21^{\circ} \mathrm{C}$ & $50^{\circ} \mathrm{C}$ & $21^{\circ} \mathrm{C}$ & $50^{\circ} \mathrm{C}$ \\
\hline 0, large $^{(a)}$ (3-days' settling) & 0.00 & \multicolumn{2}{|c|}{$\frac{1}{2.405}$} & \multicolumn{2}{|c|}{0.859} \\
\hline 0, large ${ }^{(a)}$ (75-days' settling) & 0.00 & \multicolumn{2}{|c|}{2.489} & \multicolumn{2}{|c|}{0.851} \\
\hline 0 & 0.00 & \multicolumn{2}{|c|}{2.436} & \multicolumn{2}{|c|}{0.856} \\
\hline 1 & 0.00 & 2.008 & 1.986 & & \\
\hline 2 & 0.19 & 2.308 & 1.992 & & \\
\hline 3 & 0.92 & 2.083 & 1.606 & & \\
\hline 4 & 1.18 & 1.786 & 1.554 & & \\
\hline 5 & 2.01 & 1.771 & 1.503 & & \\
\hline 6 & 3.17 & 1.583 & 1.463 & & \\
\hline 7 & 4.17 & 1.583 & 1.446 & & \\
\hline 8 & 6.92 & 1.439 & 1.438 & & \\
\hline 9 & 8.94 & 1.311 & 1.392 & & \\
\hline 10 & 10.90 & 1.246 & 1.266 & & \\
\hline 11 & 13.93 & 1.219 & 1.222 & & \\
\hline 12 & 17.94 & 1.161 & 1.198 & & \\
\hline 13 & 21.93 & 1.159 & 1.229 & & \\
\hline 14 & 32.13 & 1.141 & 1.230 & & \\
\hline 15 & 36.86 & 1.134 & 1.254 & & \\
\hline 16 & 45.94 & 1.150 & 1.275 & & \\
\hline 17 & 52.90 & 1.172 & 1.266 & & \\
\hline 18 & 59.03 & 1.165 & 1.280 & 0.959 & 0.930 \\
\hline 18, large $^{(\mathrm{a})}$ (1-day's settling) & 59.03 & 1.173 & 1.336 & 0.957 & 0.916 \\
\hline 18, large $^{(a)}$ (39-days' settling) & 59.03 & 1.200 & 1.382 & 0.950 & 0.904 \\
\hline
\end{tabular}

The densities of the starting uraninite and the respective products from the $21^{\circ} \mathrm{C}$ and $50^{\circ} \mathrm{C}$ tests were measured using both $1 \mathrm{ml}$ syringes and $15 \mathrm{ml}$ centrifuge cones. The respective density values are practically identical for the starting uraninite and the $21^{\circ} \mathrm{C}$ product by the two measurement techniques while the values differ by about $4 \%$, relative, for the $50^{\circ} \mathrm{C}$ product. Additional settling time for the larger samples increased the settled densities by $\sim 3 \%$ or less. Therefore, the settled densities measured using the $1 \mathrm{ml}$ syringes are taken to be valid. 


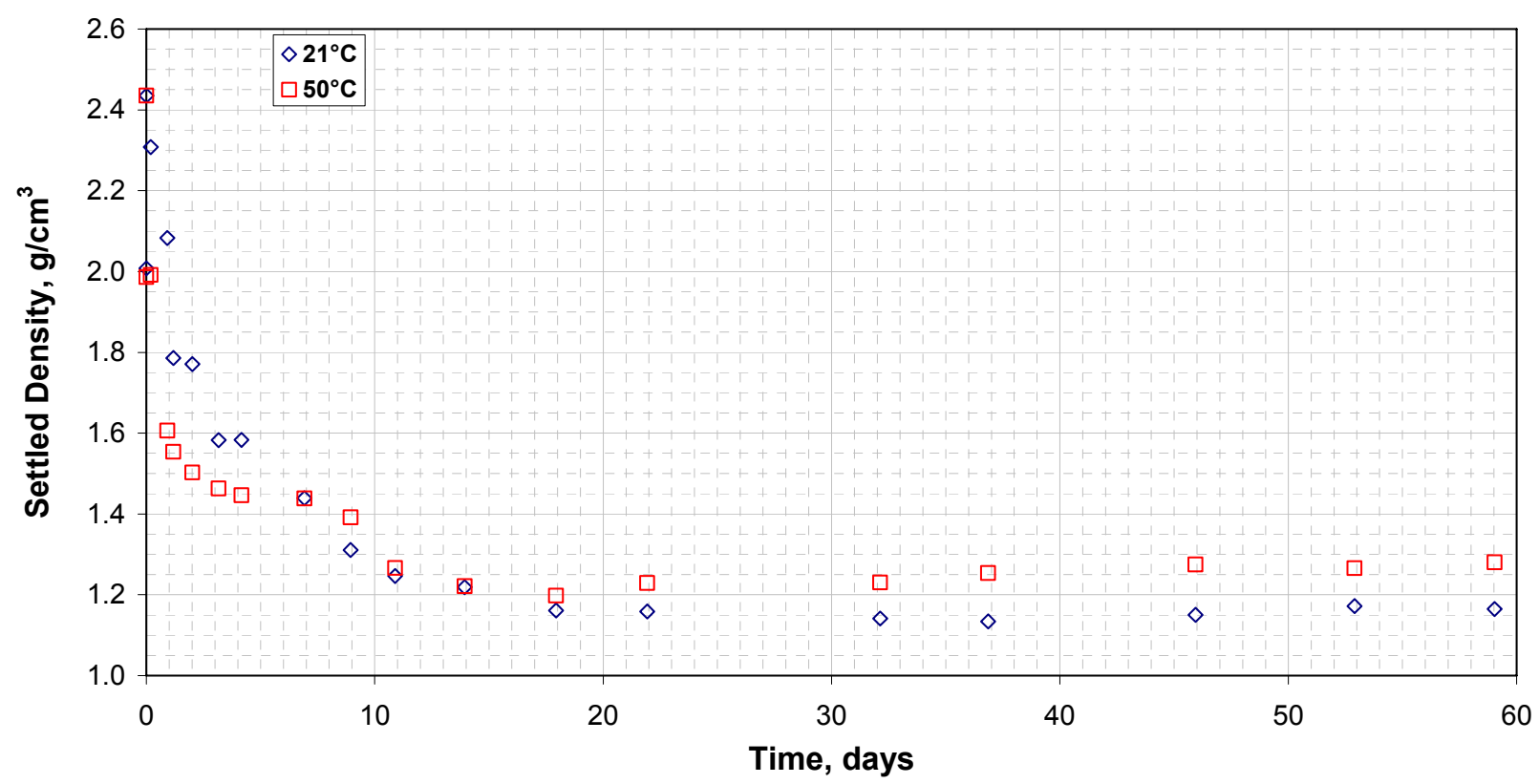

Figure 4.10. Settled Solids Densities for Uraninite-Metaschoepite Mixtures

Knowledge of the settled and particle densities of the starting uraninite and the product metaschoepite allows calculation of the volume fraction of water in their respective water-settled solids. The density of stoichiometric uraninite is $10.977 \mathrm{~g} / \mathrm{cm}^{3}$ and metaschoepite is $4.998 \mathrm{~g} / \mathrm{cm}^{3}$ (ICDD 2006). The volume fractions of water in the settled uraninite are $\sim 0.855$ based on the three measurements. The volume fraction of water in the $21^{\circ} \mathrm{C}$ settled metaschoepite product average $\sim 0.955$ for the three measurements and average $\sim 0.917$ for the $50^{\circ} \mathrm{C}$ test.

The observed settled densities for both the starting uraninite and the product metaschoepite may be compared with densities observed for sludges retrieved from the $\mathrm{K}$ Basin. The best representation of uraninite in $\mathrm{K}$ Basin sludge likely is found in canisters whose high uranium concentrations and chemically reducing environment would inhibit oxidation of uraninite to metaschoepite. The settled densities, uranium concentrations, and phases identified by XRD of KE Basin canister sludges having $>80 \mathrm{wt} \%$ uranium concentration $\left(\mathrm{UO}_{2}\right.$ is $\left.88.1 \mathrm{wt} \% \mathrm{U}\right)$ are summarized in Table 4.2.

It is seen that the density obtained for uraninite used in the present testing, $\sim 2.4 \mathrm{~g} / \mathrm{cm}^{3}$, is near that observed for KE Basin canister sludge having uranium concentrations above $80 \mathrm{wt} \%$. The KE canister sludge also shows uraninite $\left(\mathrm{UO}_{2}, \mathrm{U}_{4} \mathrm{O}_{9}\right.$, and $\left.\mathrm{U}_{3} \mathrm{O}_{7}\right)$ as the primary phases observed by XRD. The densities of the largely uraninite product obtained by gas generation testing of irradiated $\mathrm{N}$ Reactor fuel were $2.8 \mathrm{~g} / \mathrm{cm}^{3}$ for fuel particles that were 500 to $2000 \mu \mathrm{m}$ diameter and $2.5 \mathrm{~g} / \mathrm{cm}^{3}$ for $<500 \mu \mathrm{m}$ diameter (Schmidt and Delegard 2003). However, the settled sludge densities observed for KW Basin canister sludge, $\sim 3.7 \mathrm{~g} / \mathrm{cm}^{3}$ for the two sludges having $>80 \mathrm{wt} \%$ uranium, were substantially higher than observed for the uraninite used in the present testing. A small contributor to the greater density in the K Basin sludge samples may have been the presence of uranium metal, shown by gas formation in the sludge, but this effect is likely to be small. 
Table 4.2. Settled Densities, Uranium Concentrations, and Phases Identified in Uranium-Rich K Basin Sludges

\begin{tabular}{|c|c|c|c|}
\hline Sludge & Density, $\mathbf{g} / \mathrm{cm}^{3}$ & [U], dry wt\% & Phases, in Order of Prominence \\
\hline \multicolumn{4}{|c|}{ K East Canister (Makenas et al. 1997) } \\
\hline $96-01$ & 2.09 & 82 & $\mathrm{UO}_{2}, \mathrm{U}_{4} \mathrm{O}_{9}, \mathrm{U}_{3} \mathrm{O}_{7}$ \\
\hline $96-05$ & 2.34 & 88 & $\mathrm{UO}_{2}, \mathrm{U}_{4} \mathrm{O}_{9}, \mathrm{U}_{3} \mathrm{O}_{7}, \mathrm{UO}_{3} \cdot 2 \mathrm{H}_{2} \mathrm{O}, \mathrm{U}_{\text {metal }}{ }^{(\mathrm{a})}$ \\
\hline $96-13$ & 2.46 & 82 & $\mathrm{UO}_{2}, \mathrm{U}_{4} \mathrm{O}_{9}, \mathrm{U}_{3} \mathrm{O}_{7}, \mathrm{U}_{\text {metal }}{ }^{(\mathrm{a})}$ \\
\hline $96-15$ & 1.84 & 81 & $\mathrm{UO}_{2}, \mathrm{U}_{4} \mathrm{O}_{9}, \mathrm{U}_{3} \mathrm{O}_{7}, \mathrm{U}$ metal $^{(\mathrm{a})}$ \\
\hline \multicolumn{4}{|c|}{ K West Canister (Makenas et al. 1998) } \\
\hline $96-16$ & 3.83 & 81 & $\begin{array}{l}\mathrm{U}_{4} \mathrm{O}_{9}, \mathrm{UO}_{3} \cdot 2 \mathrm{H}_{2} \mathrm{O} \\
\mathrm{Na}_{2}\left(\mathrm{UO}_{2}\right)_{6}(\mathrm{OH})_{14} \cdot 2 \mathrm{H}_{2} \mathrm{O}\end{array}$ \\
\hline $96-17$ & 3.56 & 92 & $\mathrm{U}_{4} \mathrm{O}_{9}, \mathrm{UO}_{3} \cdot 2 \mathrm{H}_{2} \mathrm{O}, \mathrm{U}$ metal ${ }^{(\mathrm{a})}$ \\
\hline \multicolumn{4}{|c|}{ K East Canister, Aged $\sim 8$ Years in the Hot Cell (Delegard et al. 2007) } \\
\hline KC-2/3 M250 & $2.68^{(\mathrm{b})}$ & 68 & $\mathrm{UO}_{3} \cdot 2 \mathrm{H}_{2} \mathrm{O}$ \\
\hline KC-2/3 Whole & 2.18 & 59 & Not determined, but likely $\mathrm{UO}_{3} \cdot 2 \mathrm{H}_{2} \mathrm{O}$ \\
\hline \multicolumn{4}{|c|}{$\begin{array}{l}\text { (a) Observation of gas bubbles during settling tests indicates the presence of U metal. Sample } \\
96-01 \text { was not settled and no bubbles were observed for sample } 96-16 \text {. } \\
\text { (b) Density as measured in 2007. The density of KC-2/3 M250 increased from } 2.13 \mathrm{~g} / \mathrm{cm}^{3} \\
\text { measured in } 1999 \text { (Bredt et al. 1999). }\end{array}$} \\
\hline
\end{tabular}

The densities of the $21^{\circ} \mathrm{C}$ and $50^{\circ} \mathrm{C}$ metaschoepite products created in the present testing, $\sim 1.2$ to $1.4 \mathrm{~g} / \mathrm{cm}^{3}$, were about half that observed for KC-2/3 M250 sludge $\left(2.68 \mathrm{~g} / \mathrm{cm}^{3}\right)$ that had been aged in the hot cell to become metaschoepite as shown by XRD (Table 4.2). The settled density of KC-2/3 M250 had increased from the $2.13 \mathrm{~g} / \mathrm{cm}^{3}$ value measured eight years earlier. The lower densities observed for the oxidized uraninite prepared in the present testing may be because, as shown in Figure 4.10, the product metaschoepite particles are finer and less readily packed than those of the aged genuine sludge.

Overall, the starting uraninite has settled density near that observed for KE Basin sludge and somewhat lower than that observed for KW sludge of similar uranium concentration and crystalline phase. However, the metaschoepite produced by reaction with dissolved oxygen gas in the present testing had much lower settled density than metaschoepite produced by aging KC-2/3 M250 sludge under hot cell conditions. Note, however, that the KC-2/3 M250 sludge formed after eight years of oxic storage at $\sim 33^{\circ} \mathrm{C}$ in the hot cell may not represent metaschoepite produced in $\sim 10^{\circ} \mathrm{C}$ oxygen-poor $\mathrm{K}$ Basin or container conditions.

The fraction of uranium present as metaschoepite or other fully oxidized [i.e., U(VI)] solid phase in actual sludge in the K Basins is not known. Nevertheless, it is likely that little metaschoepite or other U(VI) phases exist under the chemically reducing anoxic conditions while in the presence of the corroding uranium metal fuel. However, over the past several years, the fuel has been removed from the Basins, the remaining KE Basin sludge has been transferred to the KW Basin, and all of the sludge has been pumped into containers. These operations imposed more oxidizing conditions to the sludge environment and have certainly increased the fraction of uranium present as metaschoepite. Characterization of the uranium oxidation state in the containerized sludge will allow determination of the degree of this transformation.

The dependence of the settled uraninite-metaschoepite solid densities are plotted as a function of the extent of the conversion from pure uraninite (stoichiometric $\mathrm{UO}_{2}$ ) to metaschoepite (stoichiometric $\mathrm{UO}_{3} \cdot 2 \mathrm{H}_{2} \mathrm{O}$ ) in Figure 4.11. The values for $\%$ conversion are provided in a later section of this report. It is seen that the solids settled densities decrease approximately linearly with extent of conversion to metaschoepite. 


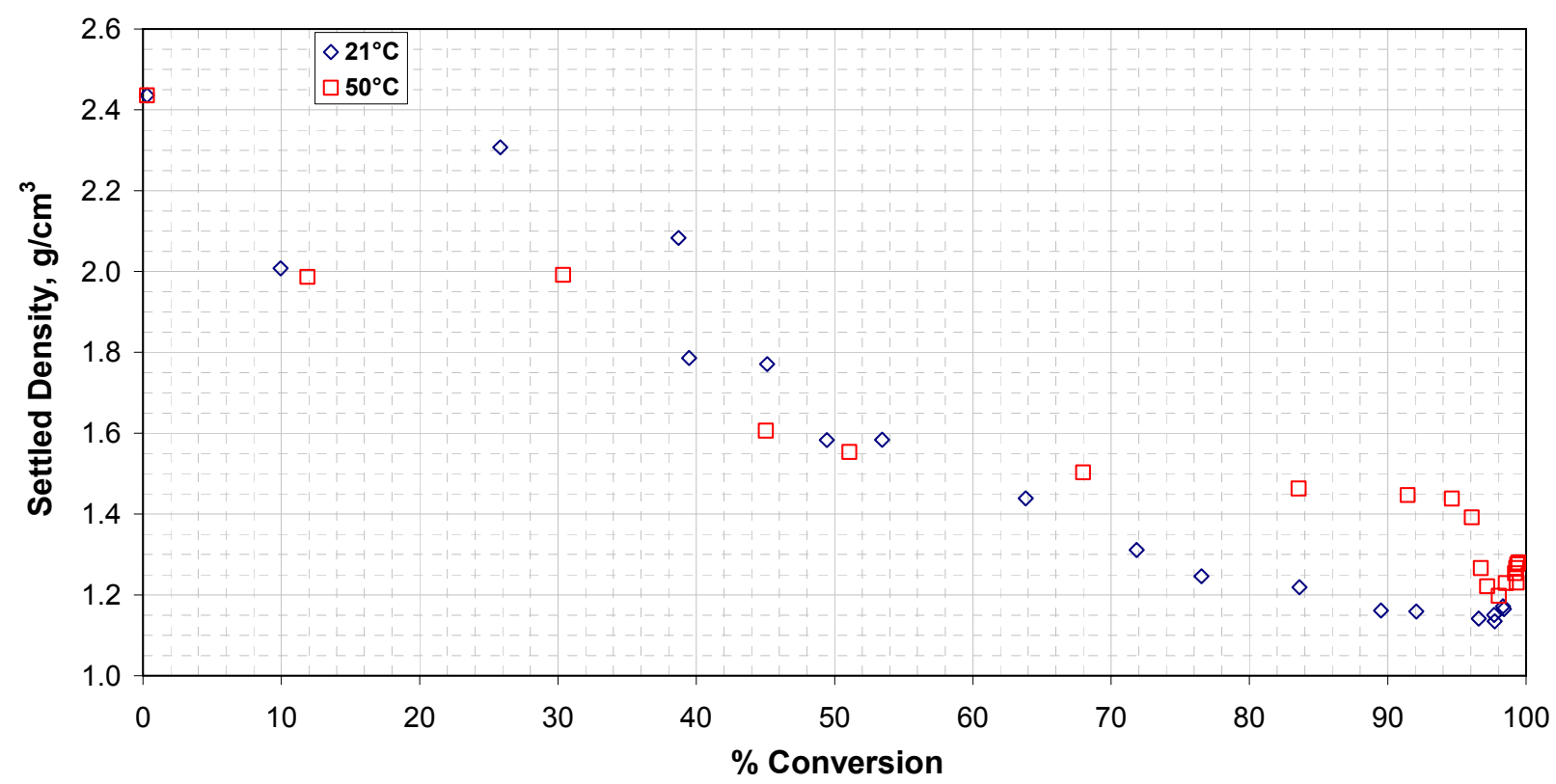

Figure 4.11. Settled Solids Density as a Function of Conversion from Pure Uraninite ( $\% \%$ Conversion) to Pure Metaschoepite (100\% Conversion)

The amount of hydrate water in the metaschoepite products prepared at $21^{\circ} \mathrm{C}$ and $50^{\circ} \mathrm{C}$ were determined by measuring the weight changes of the respective samples that had been dried to constant weight at $50^{\circ} \mathrm{C}$ after they had been heated to $105^{\circ} \mathrm{C}$ and then to $400^{\circ} \mathrm{C}$. At $50^{\circ} \mathrm{C}$, metaschoepite reaches the composition $\mathrm{UO}_{3} \cdot 2 \mathrm{H}_{2} \mathrm{O}$ while heating to $105^{\circ} \mathrm{C}$ produces "dehydrated schoepite" $\left(\mathrm{UO}_{3} \cdot 0.9 \mathrm{H}_{2} \mathrm{O}\right.$ at 105 and $150^{\circ} \mathrm{C}$ according to Sowder et al. 1999; $\mathrm{UO}_{3} \cdot 0.75 \mathrm{H}_{2} \mathrm{O}$ to $\mathrm{UO}_{3} \cdot 1.0 \mathrm{H}_{2} \mathrm{O}$ at $120^{\circ} \mathrm{C}$ according to Finch et al. 1998). Further heating to $400^{\circ} \mathrm{C}$ produces the anhydrous $\mathrm{U}(\mathrm{VI})$ oxide, $\mathrm{UO}_{3}$ (Weigel 1986).

The weight loss data registered by heating the metaschoepite samples are shown in Table 4.3. The corresponding hydrate formulas are calculated based on complete dehydration to form $\mathrm{UO}_{3}$ by drying at $400^{\circ} \mathrm{C}$. It is seen that the metaschoepite products synthesized at $21^{\circ} \mathrm{C}$ and $50^{\circ} \mathrm{C}$ correspond to the chemical formulas $\mathrm{UO}_{3} \cdot 2.02 \mathrm{H}_{2} \mathrm{O}$ and $\mathrm{UO}_{3} \cdot 1.92 \mathrm{H}_{2} \mathrm{O}$, respectively, and are within experimental error of the ideal expected $\mathrm{UO}_{3} \cdot 2 \mathrm{H}_{2} \mathrm{O}$ formula. The "dehydrated schoepite" created by heating the respective $21{ }^{\circ} \mathrm{C}$ and $50^{\circ} \mathrm{C}$ metaschoepite products to $105^{\circ} \mathrm{C}$ have experimentally equivalent hydrate formulas of $\mathrm{UO}_{3} \cdot 0.75 \mathrm{H}_{2} \mathrm{O}$ and $\mathrm{UO}_{3} \cdot 0.71 \mathrm{H}_{2} \mathrm{O}$. The derived dehydrated schoepite formulas thus have water amounts at the low end of the $\mathrm{UO}_{3} \cdot 0.75 \mathrm{H}_{2} \mathrm{O}$ to $\mathrm{UO}_{3} \cdot 1.0 \mathrm{H}_{2} \mathrm{O}$ range of formulas found for dehydrated schoepite in the technical literature (Sowder et al. 1999, Finch et al. 1998, and cited references therein).

Table 4.3. Hydrate Formula for Metaschoepite Products

\begin{tabular}{|c|c|c|c|c|}
\hline \hline Product & Property & $\mathbf{5 0}^{\circ} \mathbf{C}$ & $\mathbf{1 0 5}^{\circ} \mathbf{C}$ & $\mathbf{4 0 0}^{\circ} \mathbf{C}$ \\
\hline $\begin{array}{c}21{ }^{\circ} \mathrm{C} \\
\text { metaschoepite }\end{array}$ & Weight, $\mathrm{g}$ & 0.955 & 0.887 & 0.847 \\
\cline { 2 - 5 } & Formula & $\mathrm{UO}_{3} \cdot 2.02 \mathrm{H}_{2} \mathrm{O}$ & $\mathrm{UO}_{3} \cdot 0.75 \mathrm{H}_{2} \mathrm{O}$ & $\mathrm{UO}_{3}$ \\
\hline $\begin{array}{c}50^{\circ} \mathrm{C} \\
\text { metaschoepite }\end{array}$ & Weight, $\mathrm{g}$ & 1.504 & 1.402 & 1.342 \\
\cline { 2 - 5 } & Formula & $\mathrm{UO}_{3} \cdot 1.92 \mathrm{H}_{2} \mathrm{O}$ & $\mathrm{UO}_{3} \cdot 0.71 \mathrm{H}_{2} \mathrm{O}$ & $\mathrm{UO}_{3}$ \\
\hline
\end{tabular}




\subsection{5 pH Results}

The $\mathrm{pH}$ values of solutions associated with the slurry samples are presented in Table 4.4 and are plotted as a function of reaction time in Figure 4.12. Overall, the $\mathrm{pH}$ does not change markedly within the variability observed for the duplicate measurements. The $\mathrm{pH}$ of the initial uraninite is $\sim 5.9$, dips to about 5.5 at intermediate times, and is about 5.7-5.8 for both the $21^{\circ} \mathrm{C}$ and $50^{\circ} \mathrm{C}$ products. The slight changes in $\mathrm{pH}$ of these unbuffered waters mean that the affinities of the solid surfaces for either hydrogen or hydroxide ion $\left(\mathrm{H}^{+}\right.$or $\left.\mathrm{OH}^{-}\right)$do not greatly differ between the starting uraninite and product metaschoepite. This lack of marked effect and the lack of buffering led to the somewhat scattered $\mathrm{pH}$ readings.

Table 4.4. $\mathrm{pH}$ Values for Uraninite-Metaschoepite Mixtures

\begin{tabular}{|c|c|c|c|}
\hline \multirow{2}{*}{ Sample } & \multirow{2}{*}{$\begin{array}{c}\text { Reaction Time, } \\
\text { days }\end{array}$} & \multicolumn{2}{|c|}{ pH } \\
\hline & & $21^{\circ} \mathrm{C}^{(\mathrm{a})}$ & $50^{\circ} \mathrm{C}^{(\mathrm{a})}$ \\
\hline 1 & 0.00 & $5.87,5.65$ & 5.97 \\
\hline 2 & 0.19 & $5.94,5.72$ & 5.95 \\
\hline 3 & 0.92 & $5.64,5.44$ & 5.82 \\
\hline 4 & 1.18 & $5.23,5.32$ & 6.05 \\
\hline 5 & 2.01 & 6.13 & 5.86 \\
\hline 6 & 3.17 & $5.94,5.46$ & 5.83 \\
\hline 7 & 4.17 & $6.05,5.33$ & 5.49 \\
\hline 8 & 6.92 & $4.58,4.25$ & 5.34 \\
\hline 9 & 8.94 & $5.45,4.92$ & 5.47 \\
\hline 10 & 10.90 & $5.67,4.48$ & 5.52 \\
\hline 11 & 13.93 & 5.87 & 5.35 \\
\hline 12 & 17.94 & 5.94 & 5.22 \\
\hline 13 & 21.93 & \multirow{6}{*}{$\begin{array}{l}\text { Insufficient sample } \\
\qquad(<0.2 \mathrm{ml})\end{array}$} & 5.32 \\
\hline 14 & 32.13 & & \multirow{5}{*}{$\begin{array}{l}\text { Insufficient sample } \\
\qquad(<0.2 \mathrm{ml})\end{array}$} \\
\hline 15 & 36.86 & & \\
\hline 16 & 45.94 & & \\
\hline 17 & 52.90 & & \\
\hline 18 & 59.03 & & \\
\hline 18, large $^{(\mathrm{b})}$ & 59.03 & 5.79 & 5.68 \\
\hline \multicolumn{4}{|c|}{$\begin{array}{l}\text { (a) First given value for } 21^{\circ} \mathrm{C} \text { data from } 0.2 \text {-ml sample; second or only value is from the entire } \\
\text { supernatant sample. The } 50^{\circ} \mathrm{C} \text { test values were obtained using the entire supernatant sample } \\
\text { (b) Large sample from residual slurry; all other measurements using supernatant solutions } \\
\text { recovered for density determinations. }\end{array}$} \\
\hline
\end{tabular}

\subsubsection{Uranium Oxidation State Results}

The distributions of oxidation states in the uraninite-metaschoepite mixtures were determined by dissolving samples of the solids in $\mathrm{Na}_{2} \mathrm{SO}_{4}$-bearing $\mathrm{H}_{3} \mathrm{PO}_{4}$, measuring the absorbance spectra, and calculating the relative U(IV) and U(VI) concentrations according to their absorbances at $642.6 \mathrm{~nm}$ and $406.2 \mathrm{~nm}$, respectively. The results of these determinations for both the $21^{\circ} \mathrm{C}$ and $50^{\circ} \mathrm{C}$ test series are presented in Table 4.5. Sample 0 was withdrawn from the bottle of as-received stock uraninite from MSC and added directly to the $\mathrm{Na}_{2} \mathrm{SO}_{4}$-bearing $\mathrm{H}_{3} \mathrm{PO}_{4}$ solution with minimal air exposure. For both test temperatures, sample 1 was taken within a few minutes of introduction and complete stirring of the uraninite into the oxygen-saturated water. 
PNNL-17678

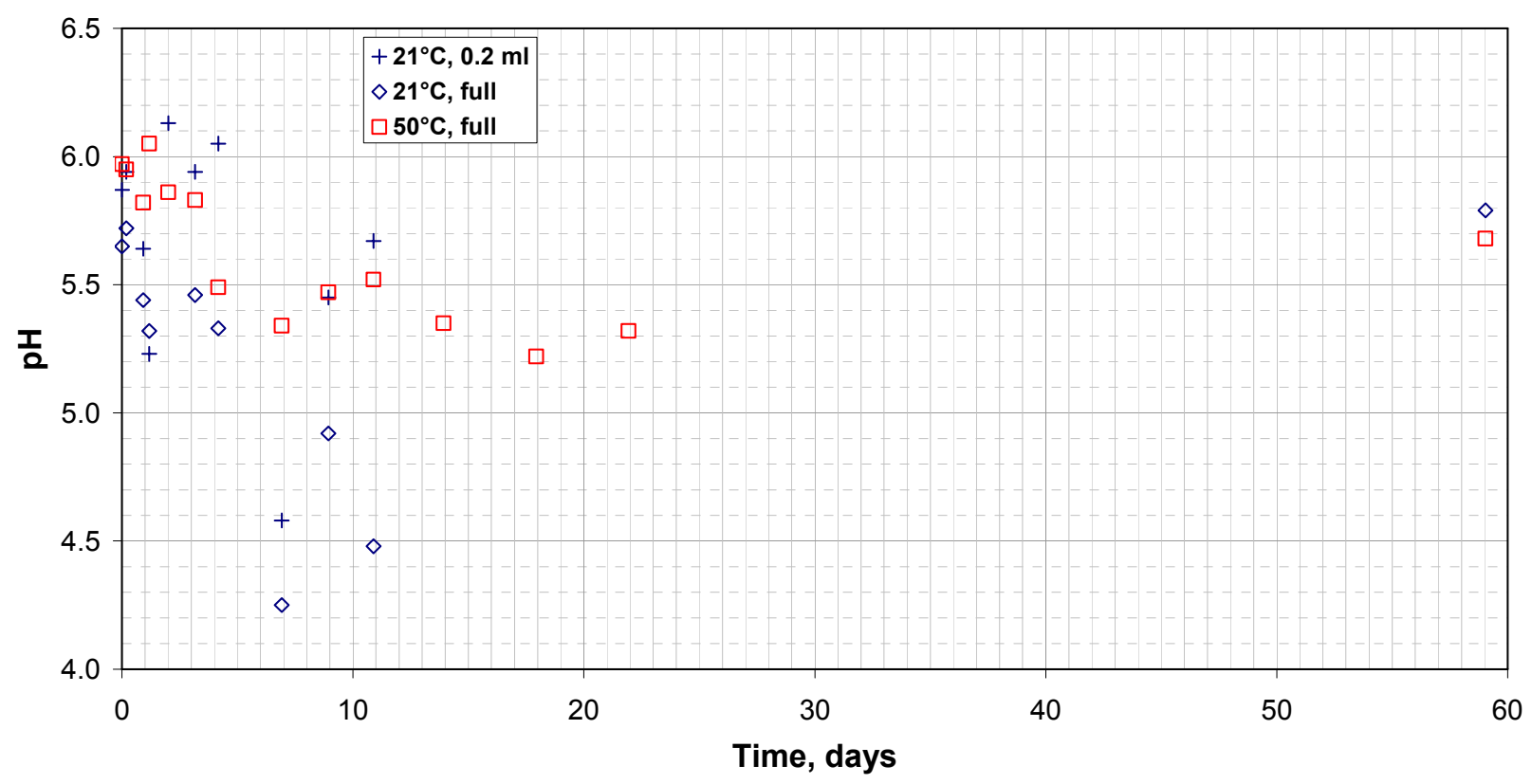

Figure 4.12. $\mathrm{pH}$ Values for Uraninite-Metaschoepite Mixtures

Table 4.5. Oxidation State Distributions in $21^{\circ} \mathrm{C}$ and $50^{\circ} \mathrm{C}$ Oxidation Test Samples as a Function of Time

\begin{tabular}{|c|c|c|c|c|c||}
\hline \multirow{2}{*}{ Sample } & \multirow{2}{*}{ Reaction } & \multicolumn{2}{|c|}{$\mathbf{2 1}^{\circ} \mathbf{C}$ Test } & \multicolumn{2}{c|}{$\mathbf{5 0}^{\circ} \mathbf{C}$ Test } \\
\cline { 3 - 6 } & Time, days & O/U Ratio & \% Conversion & O/U Ratio & \% Conversion \\
\hline 0 & 0 & 2.004 & 0.4 & 2.004 & 0.4 \\
\hline 1 & 0.00 & 2.094 & 9.4 & 2.124 & 12.4 \\
\hline 2 & 0.19 & 2.255 & 25.5 & 2.307 & 30.7 \\
\hline 3 & 0.92 & 2.384 & 38.4 & 2.450 & 45.0 \\
\hline 4 & 1.18 & 2.391 & 39.1 & 2.508 & 50.8 \\
\hline 5 & 2.01 & 2.448 & 44.8 & 2.678 & 67.8 \\
\hline 6 & 3.17 & 2.483 & 48.3 & 2.831 & 83.1 \\
\hline 7 & 4.17 & 2.530 & 53.0 & 2.912 & 91.2 \\
\hline 8 & 6.92 & 2.638 & 63.8 & 2.941 & 94.1 \\
\hline 9 & 8.94 & 2.707 & 70.7 & 2.956 & 95.6 \\
\hline 10 & 10.90 & 2.758 & 75.8 & 2.961 & 96.1 \\
\hline 11 & 13.93 & 2.823 & 82.3 & 2.964 & 96.4 \\
\hline 12 & 17.94 & 2.886 & 88.6 & 2.976 & 97.6 \\
\hline 13 & 21.93 & 2.907 & 90.7 & 2.983 & 98.3 \\
\hline 14 & 32.13 & 2.961 & 96.1 & 2.995 & 99.5 \\
\hline 15 & 36.86 & 2.974 & 97.4 & 2.993 & 99.3 \\
\hline 16 & 45.94 & 2.973 & 97.3 & 2.995 & 99.5 \\
\hline 17 & 52.90 & 2.983 & 98.3 & 2.993 & 99.3 \\
\hline 18 & 59.03 & 2.984 & 98.4 & 2.997 & 99.7 \\
\hline
\end{tabular}


The analysis of Sample 0 (taken directly from the uraninite slurry stock bottle) shows that the starting uraninite formula is $\mathrm{UO}_{2.004}$. Based on the accuracy and precision of the analyses of $\mathrm{U}_{3} \mathrm{O}_{8}\left(\mathrm{UO}_{2.66 \overline{6}}\right)$ reported in Table 3.5, which showed the formula to be $\mathrm{UO}_{2.675 \pm 0.007}$, the formula of the starting uraninite is $\mathrm{UO}_{2.004 \pm 0.007}$ and is essentially that of stoichiometric $\mathrm{UO}_{2}$. In comparison, the stoichiometry of uraninite produced by the corrosion of irradiated $\mathrm{N}$ Reactor fuel in anoxic water at $90^{\circ} \mathrm{C}$ was found to be $\mathrm{UO}_{2.08 \pm 0.03}$ (Kaminski et al. 2005). The stoichiometry was determined by an XRD procedure in which the positions of the diffraction peaks were compared with the positions observed for uranium oxides of known $\left(\mathrm{UO}_{2.03}\right.$ and $\mathrm{UO}_{2.25}$ ) stoichiometries. In the published account, the XRD sample was prepared by centrifugation to remove water and the powder suspended in ethanol and dried onto a warmed planchet. The dried sample was analyzed immediately by XRD. Although the mounting procedure was done rapidly, exposure to oxygen may have been sufficient to allow surface oxidation to occur. It is important to note that the XRD analysis occurs on the outer particle surface having the greatest exposure to air and where the oxidation would have been most pronounced.

The progress of the uraninite oxidation reaction as a function of time is plotted in Figure 4.13. These data show that the reaction is faster at $50^{\circ} \mathrm{C}$ than at $21^{\circ} \mathrm{C}$. However, as also shown in Table 4.5 , the $50^{\circ} \mathrm{C}$ reaction only proceeded to $\sim 99.3 \%$ conversion to metaschoepite even after 59 days of oxidation. The $21^{\circ} \mathrm{C}$ test was at about $98.4 \%$ conversion after 59 days but still seemed to be progressing (increasing) slowly. In both cases, the incomplete conversions were readily evident in the product spectra which displayed the characteristic U(IV) features at $\sim 600-700 \mathrm{~nm}$.

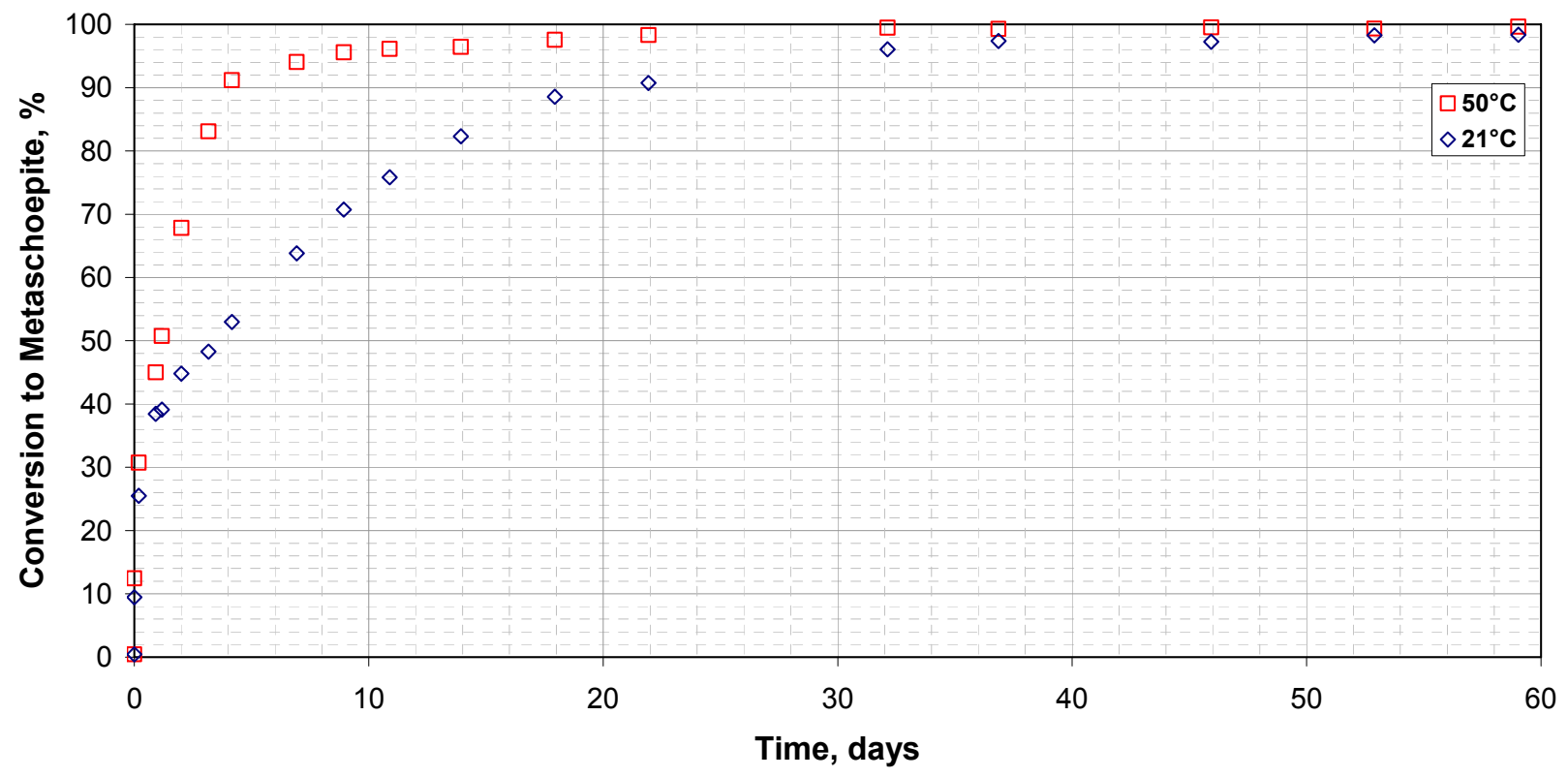

Figure 4.13. Conversion of Uraninite to Metaschoepite as a Function of Time

The reaction of uraninite with dissolved oxygen must occur on the uraninite particle solid surface, the only place where the dissolved oxygen can encounter the poorly soluble uraninite. This means that the reaction rate depends on the solid particle surface area. The much lower density of the product metaschoepite $\left(\sim 5 \mathrm{~g} / \mathrm{cm}^{3} \mathrm{vs} \sim 11 \mathrm{~g} / \mathrm{cm}^{3}\right.$ for uraninite) may cause it to spall from the parent uraninite by expansion, keeping the reacting uraninite surface relatively unencumbered by overlying reaction product. Alternatively and more likely, the uraninite may react with dissolved oxygen to produce U(VI) species which then dissolve from the surface and precipitate separately as growing metaschoepite particles. In 
either case, the rate data were interpreted using shrinking core kinetics in much the same way as shrinking core kinetics were used to understand the rate of the uranium metal reaction with water to form spalled uraninite particles (Delegard et al. 2000).

Under shrinking core kinetics, the reaction rate data may be analyzed according to the equation:

$$
(1-\mathrm{f})^{\frac{1}{3}}=1-\frac{\mathrm{k}^{\prime} \mathrm{t}}{\mathrm{r}_{0}}=1-\mathrm{kt}
$$

where $\mathrm{f}$ is the fraction reacted (in this case, the fraction of conversion of uraninite as $\mathrm{UO}_{2}$ to metaschoepite as $\mathrm{UO}_{3} \cdot 2 \mathrm{H}_{2} \mathrm{O}$ ), $\mathrm{k}^{\prime}$ is the reaction rate constant in terms of linear penetration rate, $\mathrm{t}$ is time, and $\mathrm{r}_{0}$ is the initial uraninite particle radius (see Appendix D of Delegard et al. 2000 for the derivation). The reaction progress may be followed by plotting $(1-\mathrm{f})^{1 / 3}$ against time. The slope of the plot, $\mathrm{k}$, is $\mathrm{k}^{1} / \mathrm{r}_{0}$. The plots of the $21^{\circ} \mathrm{C}$ and $50^{\circ} \mathrm{C}$ data according to the shrinking core rate law are shown in Figure 4.14.

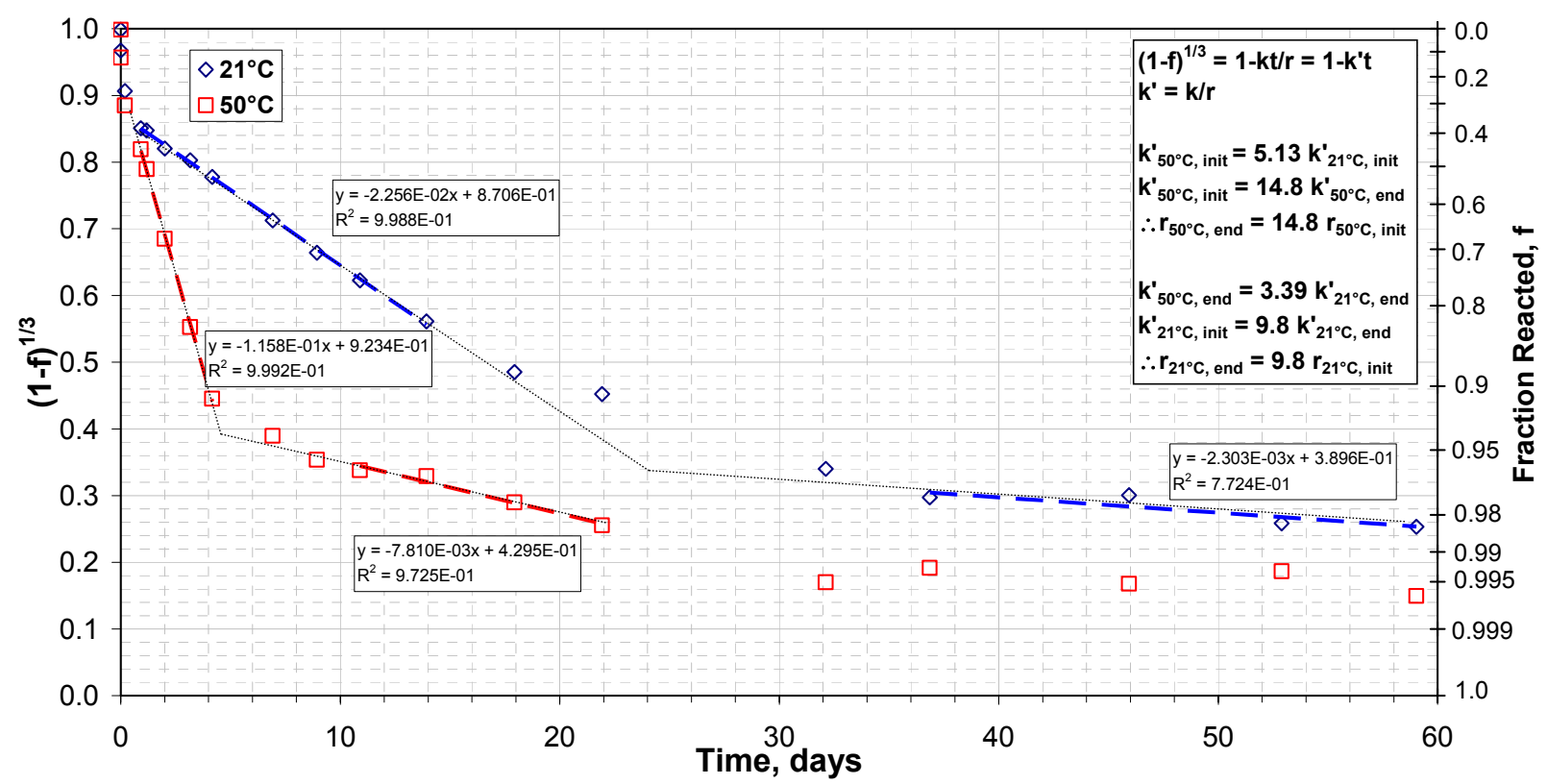

Figure 4.14. Shrinking Core Kinetics Plots of $21^{\circ} \mathrm{C}$ and $50^{\circ} \mathrm{C}$ Uraninite Oxidation Tests ( $\mathrm{f}=0.0$ for pure uraninite, $\mathrm{UO}_{2}$, and $\mathrm{f}=1.0$ for pure metaschoepite, $\mathrm{UO}_{3} \cdot 2 \mathrm{H}_{2} \mathrm{O}$ )

As shown by the linear traces in Figure 4.14, uraninite seemingly reacts with dissolved oxygen as monodisperse particles according to shrinking core kinetics for significant time spans. The initial measured $\mathrm{f}$ value is 0.004 for the uraninite as-received from MSC meaning that the starting uraninite has the nominal formula, $\mathrm{UO}_{2.004}$. As shown in Figure 4.13 and Table 4.5, about 0.4 of the uraninite (i.e., $\mathrm{f} \cong 0.4$ ) oxidized rapidly in the first day at both tested temperatures and about one-tenth $(\mathrm{f} \cong 0.1)$ oxidized in the 3 to 4 minutes required before the first sample was taken. The initial rate was too rapid to follow accurately for the sampling intervals used. The oxidation from $\mathrm{f} \cong 0.4$ to $\sim 0.9$ then proceeded at a linear rate for both the $21^{\circ} \mathrm{C}$ and $50^{\circ} \mathrm{C}$ tests. The reactions for both tests slowed after that, ultimately establishing much lower constant rates from about $\mathrm{f} \cong 0.97$ to $\sim 0.985$. The $50^{\circ} \mathrm{C}$ test seems to have reached its end at $\sim 99.5 \%$ conversion after about 30 days of oxidation while the $21^{\circ} \mathrm{C}$ test still showed 
some slow reaction even after 59 days. The final extent of conversion in the $50^{\circ} \mathrm{C}$ test is similar to the $99.3 \%$ conversion inferred based on the prominence of the ianthinite pattern in the XRD data.

The rate constant data obtained by linear regression of the straight-line portions of the kinetics curves (also shown in Figure 4.14) are presented in Table 4.6.

Table 4.6. Kinetic Parameters for Uraninite Oxidation by Dissolved Oxygen at $21^{\circ} \mathrm{C}$ and $50^{\circ} \mathrm{C}$

\begin{tabular}{|c|c|c|c|c|c|c|}
\hline \multirow{2}{*}{ Interval } & \multirow{2}{*}{$\begin{array}{c}\text { Approximate } \\
\text { Fraction Reacted, } \mathrm{f}\end{array}$} & \multicolumn{2}{|c|}{$21^{\circ} \mathrm{C}$} & \multicolumn{2}{|c|}{$50^{\circ} \mathrm{C}$} & \multirow{2}{*}{$\mathbf{k}_{50^{\circ} \mathrm{C}} / \mathbf{k}_{21^{\circ}} \mathrm{C}$} \\
\hline & & Time, days & $k$, day $^{-1}$ & Time, days & $k$, day $^{-1}$ & \\
\hline Initial & $0.4-0.9$ & $1-14$ & $-2.256 \mathrm{E}-02$ & $0.2-5$ & $-1.158 \mathrm{E}-01$ & 5.13 \\
\hline End & $0.97-0.985$ & $37-59$ & $-2.303 E-03$ & $11-22$ & $-7.810 \mathrm{E}-03$ & 3.39 \\
\hline & & $\mathbf{k}_{\text {initial }} / \mathbf{k}_{\text {end }}$ & 9.8 & $\mathbf{k}_{\text {initial }} / \mathbf{k}_{\text {end }}$ & 14.8 & \\
\hline
\end{tabular}

Because $\mathrm{k}$ (the slope) $=\mathrm{k}^{\prime} / \mathrm{r}_{0}$, for a given temperature, the slopes determined for the straight-line portions of the curves given in Figure 4.14 are inversely proportional to the radii of the uraninite particle being corroded during those intervals. Therefore, the uraninite particle radius near the end of reaction at $21^{\circ} \mathrm{C}$ (where $\mathrm{f} \cong 0.97-0.985$ ) is about 9.8-times larger than the radius earlier in the reaction (where $\mathrm{f} \cong 0.35$ 0.85 ) in light of the slope ratio data. According to the $50^{\circ} \mathrm{C}$ data, a similar difference in particle radius is found where the particle radius near the end of reaction is about 14.8-times that found in the straight-line portion earlier in the reaction.

\subsubsection{Uraninite Particle Size}

The uraninite particle size may be estimated from the kinetics plots based on published data on the rate of uraninite oxidation by dissolved oxygen gas. According to electrochemical measurements of polished $\mathrm{UO}_{2}$ pellets (Shoesmith and Sunder 1991), the oxidation rate of $\mathrm{UO}_{2}$ measured by dissolution in noncomplexing (i.e., carbonate-free) $\mathrm{pH} 9.5$ pure oxygen-saturated $\left(\sim 1.3 \times 10^{-3} \mathrm{M}\right)$ "room temperature" water (presumed to be $21^{\circ} \mathrm{C}$ ) is $8 \times 10^{-8} \mathrm{~g} / \mathrm{cm}^{2}$. day. According to the report authors, this value agrees with values obtained in other studies of non-complexing $\mathrm{pH}$-neutral aqueous solution. At a $\mathrm{UO}_{2}$ density of 11.0 $\mathrm{g} / \mathrm{cm}^{3}$, this areal corrosion rate corresponds to a linear penetration rate of $7.3 \times 10^{-9} \mathrm{~cm} /$ day $\left(7.3 \times 10^{-5}\right.$ $\mu \mathrm{m} /$ day or $0.073 \mathrm{~nm} /$ day).

The particle radii calculated from the $21^{\circ} \mathrm{C}$ data slope $\left(\mathrm{k}=\mathrm{k}^{\prime} / \mathrm{r}_{0}\right)$ for the initial $\sim 1$ to 14-day interval are $\frac{7.3 \times 10^{-2} \mathrm{~nm} / \text { day }}{2.256 \times 10^{-2} / \text { day }}=3.2 \mathrm{~nm}$ and $\frac{7.3 \times 10^{-2} \mathrm{~nm} / \text { day }}{2.303 \times 10^{-3} / \text { day }}=32 \mathrm{~nm}$ for the $\sim 32$ to 59 -day interval. The respective particle diameters, therefore, are $\sim 6$ and $64 \mathrm{~nm}$.

The 1 to 14 -day $21^{\circ} \mathrm{C}$ reaction interval encompassed the oxidation of about $44 \%$ of the total uraninite and required about a quarter of the observed oxidation time while the latter straight-line interval covered only about $2.3 \%$ of the total uraninite consumption but occupied about half of the observed oxidation time. Most of the remaining quarter of the reaction time occurred in the transition between these two straightline intervals where about $14 \%$ of the uraninite was oxidized. Oxidation of about the first $40 \%$ of the uraninite occurred within the first day of oxygen exposure, at rates too rapid to be determined reliably by the sampling frequency used. Given the linear penetration rate of $0.072 \mathrm{~nm} /$ day, however, oxidation of the first $40 \%$ of uraninite within one day implies particle diameters of $<0.15 \mathrm{~nm}$. As shown by the final plateau in the $50^{\circ} \mathrm{C}$ test, a residue of about $0.5 \%$ of the uraninite remained un-oxidized. 
In separate studies reported in the technical literature, the uraninite particle size observed for products of $90^{\circ} \mathrm{C}$ anoxic corrosion of irradiated $\mathrm{N}$ Reactor metallic uranium fuel in deionized water is stated to be $<10$ $\mathrm{nm}$ but with agglomerates as large as $1000 \mathrm{~nm}$. Light scattering analysis of a suspension of the uraninite colloids showed a mean size of $160 \pm 60 \mathrm{~nm}$ while a transmission electron microscopy (TEM) image of the agglomerated uranium oxide spheres showed the $<10$-nm particles within $\sim 150$-nm agglomerates (Kaminski et al. 2005). More TEM images from the same research are shown in a related topical report (pp. 42, 43, and 58 of Kaminski 2001). Uraninite colloids from $30^{\circ} \mathrm{C}$ anoxic corrosion of non-irradiated $\mathrm{N}$ Reactor fuel in Yucca Mountain groundwater produced discrete 5 to $10 \mathrm{~nm}$ particles with agglomerates of 100 to $200 \mathrm{~nm}$ diameter as shown by similar light scattering and TEM techniques (Fortner et al 2002). The particle size findings in the present testing, derived from uraninite oxidation rates, and the particle size as determined by application of the Scherrer equation to the uraninite XRD pattern (also $6 \mathrm{~nm}$ diameter) thus are fully consistent with the particle sizes observed by Kaminski, Fortner, and colleagues using light scattering techniques and particularly the TEM analyses.

The observed uraninite oxidation kinetics can be modeled based on the published $7.3 \times 10^{-2} \mathrm{~nm} /$ day rate at room temperature and a hypothetical collection of five uraninite particle sizes and quantities. By adjusting the particle sizes and distributions, the model was conformed to the observed rate data. The model adopted to fit the $21^{\circ} \mathrm{C}$ data takes into account that about $38 \%$ of the uraninite reacts within the first day, half is in the straight-line portion (Figure 4.14) following that, and about $2.3 \%$ of the uraninite remains even after 59 days of oxidation (and thus must encompass particles that are much greater than $2 \times(59$ days $) \times\left(7.3 \times 10^{-2} \mathrm{~nm} /\right.$ day $) \cong 9 \mathrm{~nm}$ diameter. The radii assigned to the smallest and largest particles are $0.05 \mathrm{~nm}$ and $300 \mathrm{~nm}$, respectively (although larger particles are seen in SEM photographs of the settled solids, the effect of using a size larger than $300 \mathrm{~nm}$ is minimal in this analysis). The three other particle size bins were selected based on the two straight-line fit values ( 3.2 and $32 \mathrm{~nm})$ and a transitional intermediate size which gives the curvature between the two straight-line regions.

The particle sizes and distributions that are shown in Table 4.7 are seen to fit the observed data, including the non-linear regimes, in Figure 4.15. The particle radius providing the best fit of the initial linear region wherein about half of the uraninite oxidizes is $2.5 \mathrm{~nm}$, somewhat smaller than the $3.2 \mathrm{~nm}$ particle radius projected based on the slope data only. A population of 5.0-nm radius particles added to the model provides the break between the two straight-line regimes, serves to average with the 2.5 -nm particles and approaches the 3.2-nm radius observed in rate analyses in Figure 4.14. Based on the model, 56\% of the uraninite particles are in the $2.5-\mathrm{nm}$ radius bin and about $33 \%$ in the $0.05-\mathrm{nm}$ radius bin, in approximate accordance with the observed extents of reaction for these intervals. The $5.0-\mathrm{nm}$ bin captures $8.8 \%$ of the population with the remaining $2.3 \%$ comprising the long-lived larger particles. The $1.5 \%$ ascribed to the 32-nm fraction fits the slope of the data beyond $\sim 35$ days in Figure 4.14 where particles smaller than $5 \mathrm{~nm}$ in diameter have been consumed and about $40 \%$ of the 32-nm fraction remain after 59 days of oxidation. The 300-nm particle size is arbitrarily large (with little relative change in radius) to reflect the fact that, with the heel of the $36-\mathrm{nm}$ fraction, about $(0.6 \times 1.5 \%+0.7 \%=) 1.6 \%$ of the uranium remains as U(IV) at the end of 59 days of oxidation.

Table 4.7. Model Particle Size Bins and Volume Distributions for $21^{\circ} \mathrm{C}$ Test

\begin{tabular}{|c|c|c|}
\hline \hline Bin & Radius, nm & Wt. Fraction \\
\hline 1 & 0.05 & 0.330 \\
\hline 2 & 2.5 & 0.560 \\
\hline 3 & 5.0 & 0.088 \\
\hline 4 & 32 & 0.015 \\
\hline 5 & 300 & 0.007 \\
\hline
\end{tabular}




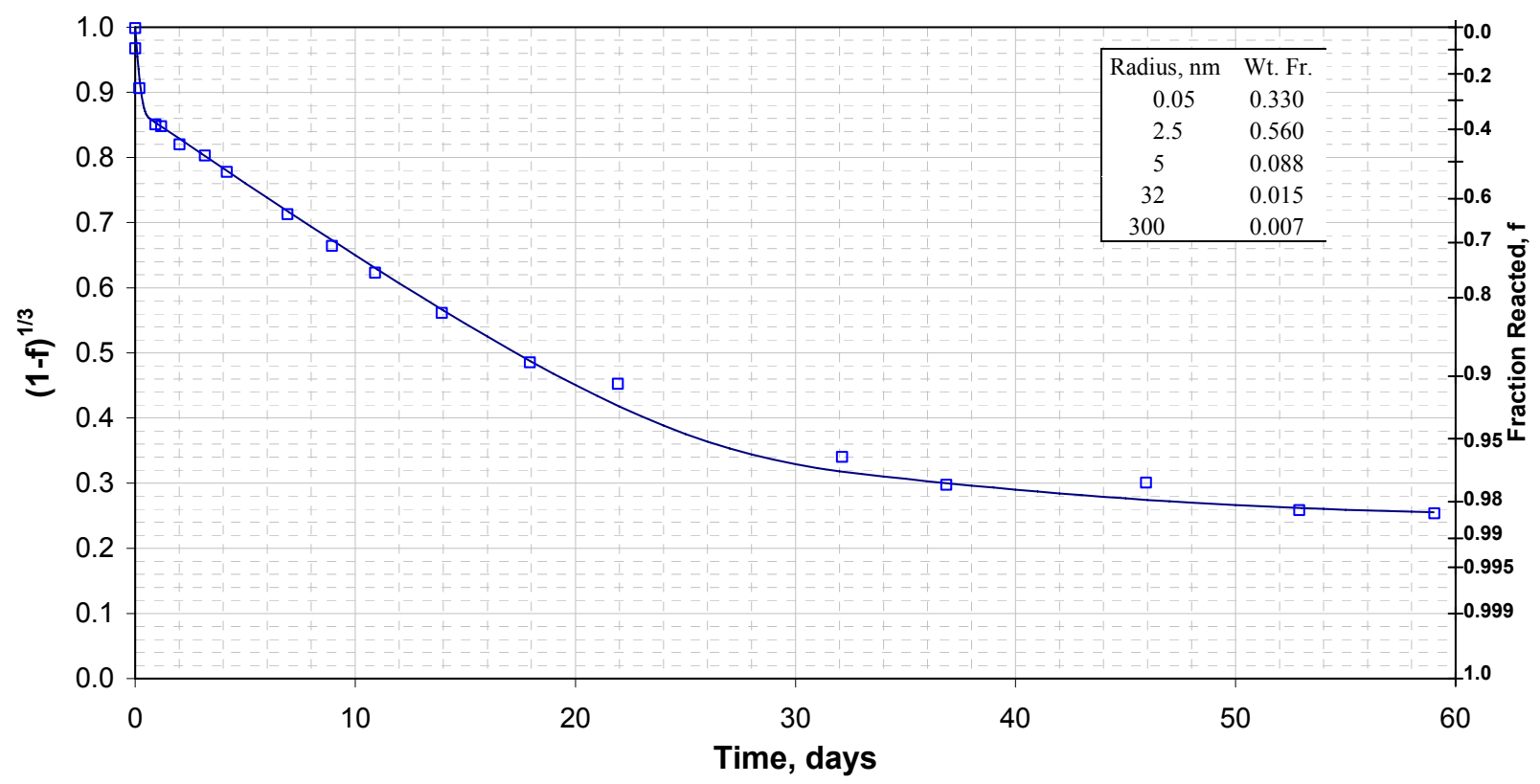

Figure 4.15. Modeling $21^{\circ} \mathrm{C}$ Uraninite Oxidation

\subsubsection{Effect of Temperature on Uraninite Oxidation Rate}

As shown in Figure 4.14 and Table 4.6, for the smaller particles dominating the reaction where $\mathrm{f} \cong 0.4-0.9$, the oxidation rate at $50^{\circ} \mathrm{C}$ is 5.13 -times greater than that $21^{\circ} \mathrm{C}$. For the larger particles which dominate the reaction at $\mathrm{f} \cong 0.97-0.985$, the rate at $50^{\circ} \mathrm{C}$ is 3.39 -times the rate at $21^{\circ} \mathrm{C}$.

The rate increase at $50^{\circ} \mathrm{C}$ is due to the intrinsically higher reaction rate of dissolved oxygen with uraninite with increased temperature. However, the rate is lower than it would be due to the lower solubility of oxygen in water at the higher temperature. Prior studies show that the uraninite oxidation rate is proportional to the first power of the dissolved oxygen concentration (Shoesmith 2000; Shoesmith and Sunder 1991; Grandstaff 1976). To determine the increase in the oxidation rate inherently due to increased temperature, the effect of the lower oxygen concentration must be accounted. Based on fits of handbook values (Perry and Green 1984), the oxygen concentration in water equilibrated with 1 atm of pure oxygen gas at $50^{\circ} \mathrm{C}$ is $9.33 \times 10^{-4} \mathrm{M}$ and is $1.35 \times 10^{-3} \mathrm{M}$ at $21^{\circ} \mathrm{C}$. For constant oxygen concentration, therefore, the rate increase caused by increasing temperature in the interval $\mathrm{f} \cong 0.4-0.9$ would be $5.13 \times\left(1.35 \times 10^{-3} / 9.33 \times 10^{-4}\right)=7.42$ and the rate increase for the interval $\mathrm{f} \cong 0.97-0.985$ would be 4.91 .

The change in reaction rate with temperature was fit to Arrhenius coordinates (in which the logarithm of the rate is proportional to the inverse absolute temperature) to determine the reaction activation energy. The Arrhenius equation may be expressed in the following form:

$$
\ln \frac{\mathrm{k}_{21^{\circ} \mathrm{C}}}{\mathrm{k}_{50^{\circ} \mathrm{C}}}=\frac{\mathrm{E}_{\mathrm{a}}}{\mathrm{R}}\left[\frac{1}{\mathrm{~T}_{50^{\circ} \mathrm{C}}}-\frac{1}{\mathrm{~T}_{21^{\circ} \mathrm{C}}}\right]
$$

where $\mathrm{R}$ is the gas constant, the temperatures are in Kelvin (absolute), $\mathrm{E}_{\mathrm{a}}$ is the activation energy, and the rates, $\mathrm{k}$, are corrected for differences in oxygen concentration. The slope of a plot of the rate data in 
Arrhenius coordinates is the negative activation energy divided by the gas constant. For the initial straight-line period, where the fraction of uraninite oxidized ranges from about 0.4 to $0.9, \mathrm{E}_{\mathrm{a}}$ is 13.1 $\mathrm{kcal} / \mathrm{mole}$ or $55 \mathrm{~kJ} / \mathrm{mole}$.

$$
\mathrm{E}_{\mathrm{a}}=\frac{\mathrm{R} \times \ln \frac{\mathrm{k}_{21^{\circ} \mathrm{C}}}{\mathrm{k}_{50^{\circ} \mathrm{C}}}}{\left[\frac{1}{\mathrm{~T}_{50^{\circ} \mathrm{C}}}-\frac{1}{\mathrm{~T}_{21^{\circ} \mathrm{C}}}\right]}=\frac{\frac{1.987 \mathrm{cal}}{\mathrm{mole} \mathrm{deg}} \times \ln \frac{1}{7.42}}{\left[\frac{1}{323.15}-\frac{1}{294.15}\right]}=13.1 \mathrm{kcal} / \mathrm{mole}
$$

A similar calculation, for the later straight-line period covering the 0.97 to 0.985 uraninite oxidation fraction, shows the activation energy to be $5.2 \mathrm{kcal} / \mathrm{mole}(22 \mathrm{~kJ} / \mathrm{mole})$. On average, $\mathrm{E}_{\mathrm{a}}=9.2 \mathrm{kcal} / \mathrm{mole}$ (or $38 \mathrm{~kJ} / \mathrm{mole}$ ). These values check poorly and, on average, are higher than the $29-34 \mathrm{~kJ} / \mathrm{mole}$ activation energies reported for oxidation of $\mathrm{UO}_{2}$ by dissolved oxygen in non-complexing aqueous solution (Shoesmith 2000). 


\subsection{Kinetic Evaluation of the Scavenging of $\mathrm{H}_{2}$ by Reaction with U(VI) Solid Phases}

Anoxic reaction of uranium metal with water produces hydrogen gas, $\mathrm{H}_{2}$. In prior hydrothermal testing of the anoxic reaction of $\mathrm{K}$ Basin sludge with water, lower amounts of $\mathrm{H}_{2}$ were observed than were expected based on fission product gas release (Bryan et al. 2004). In other tests with simulated sludge, $\mathrm{H}_{2}$ quantities were lower than were expected based on the known amounts of uranium metal used (Delegard et al. 2005). In both cases, it was postulated that the deficiency might have been caused by reaction of the $\mathrm{H}_{2}$ with $\mathrm{U}(\mathrm{VI})$ compounds. Testing was performed to determine if bubbling of $\mathrm{H}_{2}$ through aqueous suspensions of metaschoepite, prepared by reaction of uraninite with oxygen at $21^{\circ} \mathrm{C}$ and $50^{\circ} \mathrm{C}$, would chemically reduce the metaschoepite and thus provide evidence of reaction of $\mathrm{H}_{2}$ with metaschoepite.

\subsection{Experimental Apparatus, Testing, and Analysis}

The tests were conducted using the same experimental arrangement (aside from gas supply) and at the same temperatures as were originally used to prepare the metaschoepite. The tests began with the $98.4 \%$ and $99.7 \%$ metaschoepite products generated at $21^{\circ} \mathrm{C}$ and $50^{\circ} \mathrm{C}$, respectively, by oxidation of uraninite with bubbling oxygen gas for 59 days (Table 4.5). The metaschoepite produced at $21^{\circ} \mathrm{C}$ was treated with bubbling $\mathrm{H}_{2}$ at $21^{\circ} \mathrm{C}$ and the $50^{\circ} \mathrm{C}$ metaschoepite product was treated with bubbling $\mathrm{H}_{2}$ at $50^{\circ} \mathrm{C}$. At 25 days, portions of fresh uraninite were added to each test vessel to determine if the added uraninite might provide a catalytic surface to mediate the metaschoepite reduction (Ekeroth et al. 2004 and references therein). The $\mathrm{H}_{2}$ gas sparging continued until the conclusion of the tests after about 58 days with periodic solids sampling.

The samples were collected in glass vials for subsequent analysis. The supernatant water was decanted and the $\mathrm{Na}_{2} \mathrm{SO}_{4}$-bearing $\mathrm{H}_{3} \mathrm{PO}_{4}$ added to the settled solids. The solids were dissolved and the absorbance spectra gathered. The relative concentrations of U(VI) and U(IV) in the solutions were calculated based on the spectrophotometric technique described previously in this report.

\subsection{Results of $\mathrm{H}_{2}$ Scavenging Tests}

As shown in Table 5.1 and in Figure 5.1, within experimental error, the solids showed no alteration of uranium oxidation state at either $21^{\circ} \mathrm{C}$ or $50^{\circ} \mathrm{C}$ by bubbling pure $\mathrm{H}_{2}$ for the initial 25 days of testing. Uraninite was added to both tests at 25 days and the $\mathrm{H}_{2}$ bubbling continued. It is seen that for the $21^{\circ} \mathrm{C}$ test, little if any change in uranium oxidation state occurred through the final sample analysis at 51 days. Surprisingly, oxidation, not reduction, was observed after addition of the uraninite to the $50^{\circ} \mathrm{C}$ test. The $50^{\circ} \mathrm{C}$ results show that air contamination evidently occurred during or possibly after the $\mathrm{H}_{2}$ bubbling tests.

The tests of metaschoepite reduction by bubbling with $\mathrm{H}_{2}$ gas therefore were inconclusive because atmospheric oxygen was not sufficiently excluded from the system. The extreme susceptibility of uraninite to rapid oxidation by oxygen is shown in the virtually instantaneous conversion to about $10 \%$ metaschoepite in the first sampling in the uraninite oxidation tests (see Table 4.5). The very finely particulate U(IV) solids or U(IV) coatings which might have formed on the metaschoepite treated with bubbling $\mathrm{H}_{2}$ would have been even more readily oxidized than the starting particulate uraninite. 
Table 5.1. Oxidation State Distributions in $21^{\circ} \mathrm{C}$ and $50^{\circ} \mathrm{C}$ Reduction Test Samples as a Function of Time

\begin{tabular}{|c|c|c|c|c|c||}
\hline \multirow{2}{*}{ Sample } & Reaction & \multicolumn{2}{|c|}{$\mathbf{2 1}^{\circ} \mathbf{C}$ Test } & \multicolumn{2}{c||}{$\mathbf{5 0}^{\circ} \mathbf{C}$ Test } \\
\cline { 3 - 6 } & Time, days & O/U Ratio & \% U(VI) & O/U Ratio & \% U(VI) \\
\hline 1 & 0.00 & 2.985 & 98.5 & 2.996 & 99.6 \\
\hline 2 & 0.08 & 2.984 & 98.4 & 2.995 & 99.5 \\
\hline 3 & 1.02 & 2.985 & 98.5 & 2.989 & 98.9 \\
\hline 4 & 4.07 & 2.986 & 98.6 & 2.993 & 99.3 \\
\hline 5 & 7.97 & 2.985 & 98.5 & 2.994 & 99.4 \\
\hline 6 & 11.06 & 2.981 & 98.1 & 2.997 & 99.7 \\
\hline 7 & 17.97 & 2.988 & 98.8 & 2.992 & 99.2 \\
\hline 8 & 25.08 & 2.986 & 98.6 & 2.997 & 99.7 \\
\hline Uraninite added & \multicolumn{5}{|l||}{} \\
\hline 9 & 31.23 & 2.937 & 93.7 & 2.907 & 90.7 \\
\hline 10 & 35.15 & 2.939 & 93.9 & 2.951 & 95.1 \\
\hline 11 & 39.23 & 2.935 & 93.5 & 2.976 & 97.6 \\
\hline 12 & 46.23 & 2.937 & 93.7 & 2.987 & 98.7 \\
\hline 13 & 51.22 & 2.933 & 93.3 & 2.988 & 98.8 \\
\hline 14 & 58.01 & - & - & 2.991 & 99.1 \\
\hline
\end{tabular}

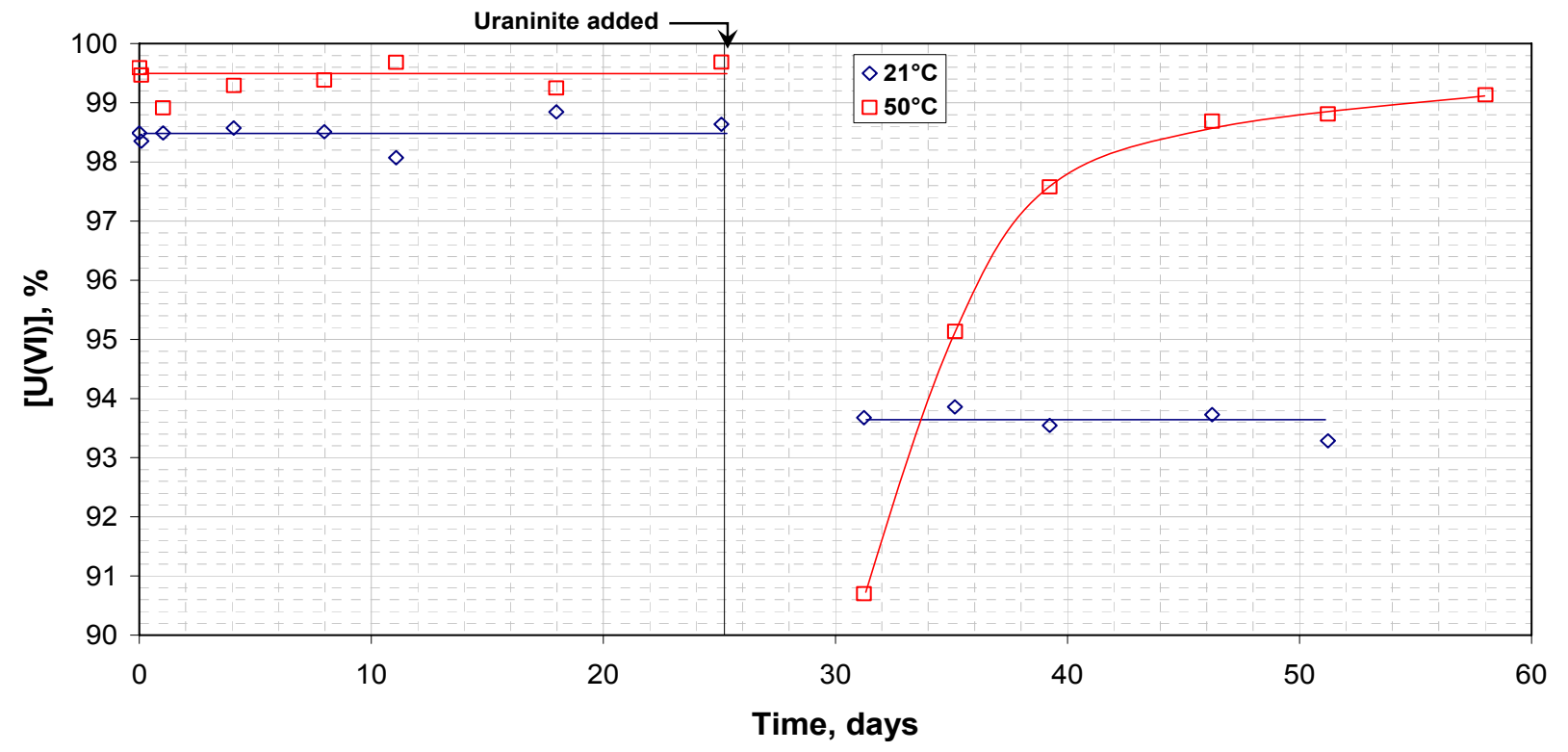

Figure 5.1. Uranium(VI) Concentrations in Solids from Tests of Metaschoepite Reduction by $\mathrm{H}_{2}$

The susceptibility of uraninite to trace air oxidation was demonstrated by observations in the $50^{\circ} \mathrm{C}$ test with $\mathrm{H}_{2}$ bubbling. An alternative method which isolates the system from atmospheric oxygen is necessary to study this reaction. The thermostatted closed vessels with gas pressure measurement used in prior gas generation testing (e.g., Delegard et al. 2000) provide the necessary isolation from air contamination while allowing sensitive monitoring of reaction progress by gas sampling and analysis. 


\subsection{Potential Analysis of Uranium Metal in Sludge by Selective Dissolution}

Determination of uranium metal concentration in sludge can be done by measurement of hydrogen gas evolution based on the stoichiometry of the anoxic corrosion reaction in water

$$
\mathrm{U}+2 \mathrm{H}_{2} \mathrm{O} \rightarrow \mathrm{UO}_{2}+2 \mathrm{H}_{2}
$$

or by quantification of the amounts of the fission product gases, krypton and xenon, released from the corroding metal for irradiated uranium metal.

Uranium metal concentrations as low as $0.004 \mathrm{wt} \%$ in $\mathrm{K}$ Basin sludge have been determined by measuring the amounts of xenon fission product gas released in the corrosion of irradiated uranium metal (Bryan et al. 2004). Krypton fission gas measurements also may be used but are less sensitive because krypton is less abundant and because the krypton isotopes are isobaric (of the same mass as), and thus may be confused with, $\mathrm{C}_{6}$ hydrocarbons. Determination of the uranium metal concentration by measurement of the amount of released fission product gas also relies on knowledge of the burn-up experienced by the irradiated fuel. The average burn-up is known to be 2900 megawatt-days per metric ton of uranium for the fuel stored in the $\mathrm{K}$ Basins (and hence the uranium metal-bearing sludge in the Basins) but can vary from element to element and even spatially within a single fuel element. Both $\mathrm{H}_{2}$ and fission product gas measurement techniques rely on long-term hydrothermal tests using gas-tight apparatus, much of which must be assembled in a hot cell. Because the uranium metal reaction penetration rate is $\sim 1 \mu \mathrm{m} /$ hour at the highest $\left(95^{\circ} \mathrm{C}\right)$ temperature available for the apparatus used in prior gas-generation testing, the time to corrode a $1 / 4$-inch particle (6350- $\mu \mathrm{m}$; the upper size-limit of K Basin sludge) to extinction (i.e., $3175 \mu \mathrm{m}$ deep) is $\sim 130$ days. Gas generation testing at higher temperatures would accelerate uranium metal reaction but would require modification of the hydrothermal apparatus to accommodate the increased water vapor pressure and to isolate the test vessel from the gas measurement manifold to prevent water condensation in the gas lines.

An alternative technique to determine uranium metal concentration in sludge is suggested by the testing described in the present report in which dissolution rates of uranium oxides in $\mathrm{Na}_{2} \mathrm{SO}_{4}$-bearing $\mathrm{H}_{3} \mathrm{PO}_{4}$ are observed to be vastly greater than those of uranium metal. Based on the large dissolution rate difference, a selective dissolution of the uranium oxides away from the uranium metal may be achieved. The uranium metal then can be dissolved by a subsequent nitric acid treatment and the dissolved uranium concentrations analyzed by established uranium analytical methods. The $\mathrm{Na}_{2} \mathrm{SO}_{4}$-bearing $\mathrm{H}_{3} \mathrm{PO}_{4}$ dissolution steps and the subsequent rinses of the insoluble heel would require one to two days of hot cell work. The selective dissolution method to measure uranium metal in sludge thus would use a simpler apparatus, provide results in much less time, and use less sludge than the hydrothermal gas generation technique described in sludge characterization testing (e.g., Delegard et al. 2000 and Bryan et al. 2004). These advantages aid in development of viable sludge treatment process options and potentially may be applied to uranium metal measurements during future actual sludge treatment processes.

The approach is to first contact the sludge with $\mathrm{Na}_{2} \mathrm{SO}_{4}$-bearing $\mathrm{H}_{3} \mathrm{PO}_{4}$ at $\sim 80^{\circ} \mathrm{C}$. Based on tests with uraninite agglomerates, this treatment is expected to dissolve the oxidized uranium compounds (e.g., 
uraninite, metaschoepite, becquerelite, soddyite) ${ }^{(a)}$ within two hours but will not appreciably attack uranium metal based on the observation that $500-\mu \mathrm{m}$ uranium metal particles required about 11 days to dissolve in $\mathrm{Na}_{2} \mathrm{SO}_{4}$-bearing concentrated $\mathrm{H}_{3} \mathrm{PO}_{4}$ at $130^{\circ} \mathrm{C}$. The $\mathrm{H}_{3} \mathrm{PO}_{4}$ solution with dissolved uranium compounds then is removed from the residual sludge solids and may be retained for uranium analysis to determine the concentration of oxidized uranium in the sludge. The solids heel is rinsed thoroughly with dilute roomtemperature nitric acid $\left(\mathrm{HNO}_{3}\right)$ to remove any entrained uranium-bearing liquid and the rinses are discarded. The residual uranium metal with other solids that are not dissolved by $\mathrm{H}_{3} \mathrm{PO}_{4}$ (e.g., sand, ion exchange media, Zircaloy cladding, Grafoil gasketing material) then is treated with hot strong $\mathrm{HNO}_{3}$ (i.e., under conditions where the uranium metal dissolution rates are rapid). The dissolution rate of uranium metal in $10 \mathrm{M} \mathrm{HNO}_{3}$ near boiling is about $500 \mu \mathrm{m} /$ hour. After several hours of heating, the uranium metal is fully dissolved and the concentrated $\mathrm{HNO}_{3}$ solution is cooled and collected for uranium concentration analysis.

Because $\mathrm{H}_{3} \mathrm{PO}_{4}$ is neither an oxidant nor a reductant for the non-metal U(IV) and U(VI) phases present in the sludge, the uranium oxidation states in the hot $\mathrm{H}_{3} \mathrm{PO}_{4}$ solutions reflect those of the starting compounds. The $\mathrm{H}_{3} \mathrm{PO}_{4}$ solution derived from dissolving the uranium compounds can be analyzed by absorption spectrophotometry to determine both the absolute and relative concentrations of U(IV) and U(VI) to arrive at total uranium present as non-metal compounds and the distribution of the uranium oxidation states. These concentrations, however, may be compromised by any uranium that is absorbed on the ion exchange material as described later in this section.

To determine the quantities of uranium present as metal in the sludge, the total uranium concentrations in the $\mathrm{HNO}_{3}$ solutions must be measured. This can be accomplished using the kinetic phosphorescence analysis (KPA) procedure established for routine use in the RPL. ${ }^{\text {(b) }}$ Note that this technique also may be used to determine total uranium concentration present as oxide in the $\mathrm{H}_{3} \mathrm{PO}_{4}$ solution to confirm the spectrophotometric method or may be used exclusively if knowledge of the oxidation state distribution is not required. The KPA technique is very sensitive, capable of providing quantitative results for solution concentrations as low as $0.02 \mathrm{ppm}$. For this reason, serial dilutions of the leaching solutions will be necessary to decrease concentrations within range of the KPA method.

In addition to its presence in the $\mathrm{K}$ Basin sludge as oxidized compounds and as metal, uranium also may be present in ionic form, adsorbed onto solid surfaces despite the low uranium solution concentrations in the $\mathrm{pH}$-neutral sludge. In the acid dissolution steps, the uranium compounds will dissolve, the solution concentrations will increase greatly, and adsorption onto solids, particularly ion exchange media, will increase. In strong $\mathrm{H}_{3} \mathrm{PO}_{4}$, the dissolved uranium may be present as cationic, neutral, or anionic U(IV) and $\mathrm{U}(\mathrm{VI})$ complexes. In strong $\mathrm{HNO}_{3}$, any $\mathrm{U}(\mathrm{IV})$ is oxidized to $\mathrm{U}(\mathrm{VI})$ and cationic, neutral, or anionic nitrate complexes of $\mathrm{U}(\mathrm{VI})$ of the form $\mathrm{UO}_{2}\left(\mathrm{NO}_{3}\right)_{\mathrm{x}}{ }^{(\mathrm{x}-2)-}$ exist. These species may adsorb onto the mixed bed cation/anion organic ion exchange resin (OIER) or the inorganic ion exchanger, Zeolon 900 (the mineral mordenite), present in many of the $\mathrm{K}$ Basin sludge materials. The effects of the presence of these ion exchangers must be determined in the potential development of selective dissolution as a method to quantify uranium metal in $\mathrm{K}$ Basin sludge.

(a) Becquerelite $\left[\mathrm{Ca}\left(\mathrm{UO}_{2}\right)_{6} \mathrm{O}_{4}(\mathrm{OH})_{6}\left(\mathrm{H}_{2} \mathrm{O}\right)_{8}\right]$ and soddyite $\left[\left(\mathrm{UO}_{2}\right)_{2} \mathrm{SiO}_{4} \cdot 2 \mathrm{H}_{2} \mathrm{O}\right]$ have been observed in sludge and hydrothermal sludge products (Delegard et al. 2007b). Minor amounts of other oxidized (non-metal) uranium compounds also may be present in sludge.

(b) Soderquist, CZ. 2001. Uranium by Kinetic Phosphorescence Analysis. RPG-CMC-4014, Rev. 1, Pacific Northwest National Laboratory, Richland, WA. 
Further development and demonstration of the selective dissolution technique, including studies of the efficacy of intermediate dilute acid rinsing and the influence of both OIER and mordenite on uranium uptake, are proposed as part of studying this potential method to measure the uranium metal concentration in K Basins sludge. 


\subsection{Conclusions}

A spectrophotometric method was developed to determine oxidation state distributions for U(IV) and $\mathrm{U}(\mathrm{VI})$ oxides by measurement of the optical absorbance of their $\mathrm{Na}_{2} \mathrm{SO}_{4}$-bearing $\mathrm{H}_{3} \mathrm{PO}_{4}$ solutions at $642.6 \mathrm{~nm}$ and $406.2 \mathrm{~nm}$, respectively. The technique was validated using uranium octaoxide $\left(\mathrm{U}_{3} \mathrm{O}_{8}\right)$ and found to provide accurate $\mathrm{U}(\mathrm{IV})$ and $\mathrm{U}(\mathrm{VI})$ concentrations and uranium oxidation state distributions to about $0.001 \mathrm{M}$ total uranium. The average oxygen/uranium $(\mathrm{O} / \mathrm{U})$ ratio is $2.66 \overline{6}$ for $\mathrm{U}_{3} \mathrm{O}_{8}$ and was found to be $2.675 \pm 0.007$ (at one standard deviation) in measurements of five varying concentration (0.003-0.07 M) uranium solutions of $\mathrm{U}_{3} \mathrm{O}_{8}$ and $\sim 2.667$ for the tests with the highest $(0.03$ and $0.07 \mathrm{M})$ uranium concentrations. Because the $\mathrm{O} / \mathrm{U}$ ratio for $\mathrm{UO}_{2}$ [pure $\mathrm{U}(\mathrm{IV})$ ] is 2.000 and $\mathrm{UO}_{3} \cdot 2 \mathrm{H}_{2} \mathrm{O}$ [pure $\mathrm{U}(\mathrm{VI})]$ is 3.000 , a difference of 1.000 , the precision of the $\mathrm{O} / \mathrm{U}$ measurement is $\pm 0.2-0.3 \%$ (relative) and the precision of the degree of conversion is $\pm 0.7 \%$ (relative), both at one standard deviation.

The effects of varying water concentration and time on the spectra were accounted in performing this work. The effect of water is minimized by selection of analysis wavelengths having minimum dependence on water concentration. The effect of time is low if the samples are analyzed within a few days of dissolution and is negligible if the samples are kept in darkness. Continuous fluorescent illumination reduced about $0.02 \%$ of the $\mathrm{U}(\mathrm{VI})$ per day and had no effect on $\mathrm{U}(\mathrm{IV})$. No U(VI) reduction was observed for samples kept in the dark.

The spectrophotometric method was applied to monitor the oxidation state distribution of the starting, intermediate, and product uranium oxides in the dissolved oxygen gas oxidation of uraninite to form metaschoepite at $21^{\circ} \mathrm{C}$ and $50^{\circ} \mathrm{C}$. The uraninite had been prepared by anoxic oxidation of uranium metal by $60^{\circ} \mathrm{C}$ water and the metaschoepite by bubbling pure oxygen into aqueous suspensions of uraninite. The physical appearance (color, particle inclusions), SEM images, XRD patterns, and settled densities of the solids and the accompanying solution $\mathrm{pH}$ also were observed in the testing of uraninite oxidation to metaschoepite.

The color of the starting uraninite is intensely black while the product metaschoepite is yellow-green. However, even for the product undergoing the longest exposure to oxygen bubbling, discrete black particles continued to be visible. The black particles were postulated to be residual uraninite based on their appearance and the continuing presence of U(IV) as determined by spectrophotometric analysis of the dissolved solids. The intensity of the uraninite blackness in the settled solids is appreciated by comparing their appearance and color to their degree of conversion. Discernable lightening of the blackness of the intermediate solids did not become apparent until about $50 \%$ of the uraninite had converted to metaschoepite (i.e., the average uranium oxidation state reached about 5, or $\mathrm{UO}_{2.5}$ ). The yellow-green (as opposed to gray) color only became apparent after about $80 \%$ conversion had occurred (uranium oxidation state $\cong 5.6$, or $\mathrm{UO}_{2.8}$ ).

The starting uraninite and the $21^{\circ} \mathrm{C}$ and $50^{\circ} \mathrm{C}$ products were examined by XRD. The starting uraninite contained primarily $\mathrm{UO}_{2}$ but minor peaks of $\mathrm{U}_{3} \mathrm{O}_{8}$ also were observed with accompanying $\mathrm{U}_{3} \mathrm{O}_{7}$. A uraninite particle size of $6 \mathrm{~nm}$ was estimated based on interpretation of the $\mathrm{UO}_{2}$ peak broadness by the Scherrer equation. Both the $21^{\circ} \mathrm{C}$ and $50^{\circ} \mathrm{C}$ products were identified as being metaschoepite but with a small $(\sim 2 \%)$ contribution due to ianthinite. The presence of ianthinite, in which the average uranium

oxidation state is $5.33 \overline{3}$, indicates incomplete oxidation to the full U(VI) state. The XRD patterns for the products were nearly identical and also closely matched the pattern observed for KE canister sludge 
sample KC-2/3 M250 that had been stored under moist and oxidizing hot cell conditions for about eight years and had converted from a mixture of uraninite and metaschoepite.

The starting uraninite and samples of the oxidizing uraninite materials after about $1 / 3,2 / 3$, and nearly complete reaction with oxygen were examined by SEM. The smallest discernable particles in the starting uraninite were rounded and about $0.1 \mu \mathrm{m}$ in diameter. As the oxidation reaction proceeded at both $21^{\circ} \mathrm{C}$ and $50^{\circ} \mathrm{C}$, crystals with distinct straight edges and defined angles formed. The products after essentially complete reaction at $21^{\circ} \mathrm{C}$ had thin hexagonal shape $(\sim 0.1 \mu \mathrm{m}$ thick and up to $2 \mu \mathrm{m}$ across $)$. The $50^{\circ} \mathrm{C}$ product particles were thicker and more rounded than the $21^{\circ} \mathrm{C}$ particles. In comparison, blocky metaschoepite particles (up to $5 \mu \mathrm{m}$ wide and $1 \mu \mathrm{m}$ thick) were found in $\mathrm{KC}-2 / 3 \mathrm{M} 250$ sludge from the $\mathrm{KE}$ Basin that had been stored for eight years (since 1999) under warm $\left(\sim 30-33^{\circ} \mathrm{C}\right)$, moist, and oxic hot cell conditions.

The settled solids densities decreased from $\sim 2.4 \mathrm{~g} / \mathrm{cm}^{3}$ for the starting uraninite to $\sim 1.2 \mathrm{~g} / \mathrm{cm}^{3}$ for the product metaschoepite with intermediate values found as oxidation proceeded. The decrease in settled solids density was roughly proportional to the degree of conversion of uraninite to metaschoepite. The uraninite settled solids density is near that observed for KE Basin canister sludge but lower than that observed for KW canister sludge. However, the densities of at least some of the actual K Basin sludge samples likely were enhanced due to the presence of uranium metal particles and potentially also because of better packing of the more equant (equal-dimensioned) particles in the genuine sludge. The density of the settled metaschoepite aqueous slurry product generated in the present testing was significantly lower than that of the largely metaschoepite solid slurry in the hot cell-aged sample KC-2/3 M250. Based on weight losses when the $50^{\circ} \mathrm{C}$-dried product solids were heated to $400^{\circ} \mathrm{C}$, the water content corresponds to the formula $\mathrm{UO}_{3} \cdot 1.92 \mathrm{H}_{2} \mathrm{O}$ to $\mathrm{UO}_{3} \cdot 2.02 \mathrm{H}_{2} \mathrm{O}$, within experimental error of the expected $\mathrm{UO}_{3} \cdot 2 \mathrm{H}_{2} \mathrm{O}$ formula.

The $\mathrm{pH}$ of the waters associated with the uraninite, metaschoepite, and intermediate solids ranged from about 5.5 to 6.0 but with high variability, reflecting the low degree of $\mathrm{pH}$ buffering provided by the deionized water and the solids surfaces. No distinct trend in $\mathrm{pH}$ was shown as a function of the degree of the uraninite-to-metaschoepite conversion.

The rate of the oxidation reaction of uraninite water suspensions to metaschoepite by dissolved oxygen was about 5.1-times greater at $50^{\circ} \mathrm{C}$ than at $21^{\circ} \mathrm{C}$. Taking into account the increased solubility of oxygen in water at lower temperature and the reported first-order dependence of rate on oxygen concentration, the reaction rate was about 7.4 -times greater at $50^{\circ} \mathrm{C}$ than at $21^{\circ} \mathrm{C}$. The reaction at $50^{\circ} \mathrm{C}$ proceeded to about $99.5 \%$ conversion after about 30 days of oxidation but did not proceed beyond this point to the end of testing at 59 days. The reaction at $21{ }^{\circ} \mathrm{C}$ was proceeding slowly by the end of the 59 -days of oxygen bubbling and had reached $98.4 \%$ conversion.

As might be expected, the rate of conversion of solid uraninite to metaschoepite by dissolved oxygen gas appeared to be limited by the particle surface area. Accordingly, the reaction was found to be modeled well by shrinking core kinetics. Plotting of the rate data according to a shrinking core rate law showed two distinct regimes of straight-line behavior indicating monodisperse particle size in those regimes. For both the $21{ }^{\circ} \mathrm{C}$ test and the $50^{\circ} \mathrm{C}$ test, the two regimes occurred at about 40 to $90 \%$ conversion and at about 97 to $98.5 \%$ conversion. Based on the known oxidation rate of $\mathrm{UO}_{2}$ in oxygen-saturated room temperature water, the straight-line regimes corresponded to uraninite particle radii of 3.2 and $32 \mathrm{~nm}$ ( $\sim 6$ and $60 \mathrm{~nm}$ diameter, respectively). These dimensions are comparable to the respective sizes of individual uraninite particles and particle agglomerates observed by TEM examination of irradiated 
$\mathrm{N}$ Reactor fuel corroded anoxically in $90^{\circ} \mathrm{C}$ water and non-irradiated $\mathrm{N}$ Reactor fuel corroded anoxically in $90^{\circ} \mathrm{C}$ groundwater as reported in the technical literature. The $\sim 6-\mathrm{nm}$ particle size also corresponds to the particle size inferred by interpretation of the XRD peak broadness using the Scherrer equation.

It has been postulated that some fraction of hydrogen gas generated during anoxic aqueous corrosion of uranium metal is consumed by chemically reducing U(VI) compounds such as metaschoepite. Testing was performed to verify and quantify this reaction pathway and quantify the reaction kinetics. The tests involved bubbling hydrogen gas through metaschoepite and metaschoepite/uraninite suspensions at $\sim 21^{\circ} \mathrm{C}$ and $50^{\circ} \mathrm{C}$. The tests were inconclusive because atmospheric oxygen was not sufficiently excluded from the system such that the very finely particulate U(IV) solids or U(IV) coatings which might have formed on the metaschoepite, if present, would have been easily re-oxidized before analysis. An alternative method which isolates the metaschoepite or metaschoepite/uraninite system from interference by atmospheric oxygen, such as reaction in a closed vessel with gas composition monitoring, is necessary to study this reaction.

Based on observations and measurements performed during uranium oxide characterization and kinetics studies, a selective sludge dissolution approach was identified that potentially can provide a rapid technique to determine uranium metal concentration in sludge. Uranium oxides dissolve rapidly in concentrated $\mathrm{H}_{3} \mathrm{PO}_{4}$ under conditions wherein very little uranium metal dissolution occurs. Because of this difference, a selective dissolution of uranium oxides away from the uranium metal can occur. The dissolved uranium oxides can be decanted and the residual solids containing the uranium metal rinsed free of the dissolved oxides with serial dilute nitric acid washes. A subsequent strike of the residue from the $\mathrm{H}_{3} \mathrm{PO}_{4}$ strike with strong heated $\mathrm{HNO}_{3}$ dissolves the uranium metal. The resulting $\mathrm{HNO}_{3}$ digestate can be analyzed for uranium via standard analytical techniques. Further development and demonstration of this technique is suggested for separate study.

In summary, the testing:

- Led to development of a rapid, accurate, and precise spectrophotometric means to measure uranium oxidation state in uranium oxide materials and slurries. This method can be applied to measure the distribution of oxidation state in uranium oxides in $\mathrm{K}$ Basin sludge.

- Showed that the uraninite produced by anoxic corrosion of uranium metal has exceedingly fine particle size (6-nm diameter) and that the particles also evidently agglomerate. The particle size was measured by two independent means.

- Showed that the uraninite produced by anoxic uranium metal corrosion has the formula $\mathrm{UO}_{2.004 \pm 0.007}$; i.e., is practically stoichiometric $\mathrm{UO}_{2}$.

- Showed that the $\mathrm{UO}_{2}$ produced by uranium metal corrosion in anoxic water is susceptible to oxidation by atmospheric oxygen. This was demonstrated by bubbling oxygen gas through uraninite water suspensions. The oxidation rate increases with increasing temperature.

- Showed that the oxidation of $\mathrm{UO}_{2}$ with oxygen produces metaschoepite, $\mathrm{UO}_{3} \cdot 2 \mathrm{H}_{2} \mathrm{O}$. The metaschoepite particles are flatter and wider when prepared at $21^{\circ} \mathrm{C}$ than the particles prepared at $50^{\circ} \mathrm{C}$. These particles are much smaller than the metaschoepite observed in prolonged exposure of actual $\mathrm{K}$ Basin sludge to warm moist oxidizing conditions.

- Characterized both the uraninite produced by anoxic uranium metal corrosion and the metaschoepite produced by reaction of uraninite aqueous slurries with oxygen for their use in engineering and process development testing. 
- Led to proposal of a method to determine uranium metal concentrations in sludge by a selective dissolution technique. The technique is based on the vastly more rapid dissolution rate of uranium oxide than of uranium metal in phosphoric acid observed in the present testing. The selective dissolution technique to determine uranium metal concentration in sludge can be developed under separate testing.

Scavenging of hydrogen by reaction with metaschoepite is suspected of occurring in prior studies of sludge reaction with anoxic water. However, tests of the potential reaction of metaschoepite and metaschoepite/uraninite aqueous slurries with bubbling hydrogen gas at $21^{\circ} \mathrm{C}$ and $50^{\circ} \mathrm{C}$ were inconclusive in demonstrating if the $\mathrm{H}_{2}$ could chemically reduce metaschoepite, apparently because of contamination with atmospheric oxygen. Testing with a closed vessel to isolate the solids from the air atmosphere and allow careful monitoring of the gas composition is a potential means to study this reaction. 


\subsection{References}

Ahmed, MK and NL Sreenivasan. 1986. "Spectrophotometric Determination of Nonstoichiometry in Hyperstoichiometric Uranium Dioxide,” Analytical Chemistry 58:2479-2481.

Bredt, PR, CH Delegard, AJ Schmidt, and KL Silvers. 1999. Testing and Analysis of Consolidated Sludge Samples from the 105 K East Basin Floor and Canisters. PNNL-13341, Pacific Northwest National Laboratory, Richland, WA (http://www.pnl.gov/main/publications/external/technical_reports/PNNL13341.pdf).

Bryan, SA, CH Delegard, AJ Schmidt, RL Sell, KL Silvers, SR Gano, and BM Thornton. 2004. Gas Generation from K East Basin Sludges - Series II Testing. PNNL-13446, Rev. 1, Pacific Northwest National Laboratory, Richland, WA (http://www.pnl.gov/main/publications/external/technical_reports/PNNL13446Rev1.pdf).

Clayton, JC. 1961. Page 91 of Uranium Dioxide: Properties and Nuclear Applications, J Belle, editor, United States Atomic Energy Commission, Washington, DC.

Delegard, CH, SA Bryan, AJ Schmidt, PR Bredt, CM King, RL Sell, LL Burger, and KL Silvers. 2000. Gas Generation from K East Basin Sludges - Series I Testing. PNNL-13320, Pacific Northwest National Laboratory, Richland, WA (http://www.pnl.gov/main/publications/external/technical_reports/PNNL-13320.pdf).

Delegard, CH, AJ Schmidt, RL Sell, SI Sinkov, SA Bryan, SR Gano, and BM Thornton. 2004. Final Report - Gas Generation Testing of Uranium Metal in Simulated K Basin Sludge and in Grouted Sludge Waste Forms. PNNL-14811, Pacific Northwest National Laboratory, Richland, WA (http://www.pnl.gov/main/publications/external/technical_reports/PNNL-14811.pdf).

Delegard CH, AJ Schmidt, SI Sinkov, SA Bryan, RL Sell, SR Gano, and BM Thornton. 2005. Uranium Metal Reaction in Simulated K Basins Sludge and in Grouted Sludge Waste Forms. PNNL-SA-45106, Pacific Northwest National Laboratory, Richland, WA.

Delegard, CH, AJ Schmidt, and BM Thornton. 2007a. Hydrothermal Testing of K Basin Sludge and N Reactor Fuel at Sludge Treatment Project Operating Conditions. PNNL-16496, Pacific Northwest National Laboratory, Richland, WA.

Delegard, CH, AJ Schmidt, and AP Poloski. 2007b. Test Plan: Sludge Treatment Project Corrosion Process Chemistry Follow-on Testing. PNNL-16776, Pacific Northwest National Laboratory, Richland, WA.

Ekeroth, E, M Jonsson, TE Eriksen, K Ljungqvist, S Kovács, and I Puigdomenech. 2004. "Reduction of $\mathrm{UO}_{2}{ }^{2+}$ by $\mathrm{H}_{2}$," Journal of Nuclear Materials 334:35-39.

Finch, RJ, FC Hawthorne, and RC Ewing. 1998. "Structural Relations among Schoepite, Metaschoepite, and 'Dehydrated Schoepite,'” The Canadian Mineralogist 36:831-845. 
Fortner, JA, CJ Mertz, MM Goldberg, and S Seifert. 2002. Characteristics of Aqueous Colloids Generated by Corrosion of Metallic Uranium Fuel. ANL/CMT/CP-106586, Argonne National Laboratory, Argonne, IL.

Grandstaff. 1976. “A Kinetic Study of the Dissolution of Uraninite,” Economic Geology 71(8):14931506.

ICDD. 2006. International Centre for Diffraction Data, Inc., database PDF-2, Release 2006.

Kaminski, MD. 2001. Batch Tests with Unirradiated Uranium Metal Fuel-Program Report. ANL01/33, Argonne National Laboratory, Argonne, IL (http://www.ipd.anl.gov/anlpubs/2002/02/42106.pdf).

Kaminski, MD, NM Dimitrijevic, CJ Mertz, and MM Goldberg. 2005. "Colloids from the Aqueous Corrosion of Uranium Nuclear Fuel," Journal of Nuclear Materials 347:77-87.

Kolthoff, IM, PJ Elving, and EB Sandell. 1962. Pages 21-22 and 74-76 of Treatise on Analytical Chemistry, Part II, Analytical Chemistry of the Elements, Volume 9, "U • The Actinides," Interscience Publishers, New York, NY.

Liley, PE, RC Reid, and E Buck. 1984. "Physical and Chemical Data," Chapter 3 in Perry's Chemical Engineers' Handbook, RH Perry and D Green (editors), McGraw Hill Book Co., New York, NY.

Lister, BAJ and RJ Richardson. 1957. The Preparation of Uranium Trioxide by Thermal Decomposition of Uranyl Nitrate, AERE C/R 2276, Atomic Energy Research Establishment, Harwell, Berkshire, UK.

Makenas, BJ, TL Welsh, RB Baker, DR Hansen, and GR Golcar. 1996. Analysis of Sludge from Hanford K East Basin Floor and Weasel Pit. WHC-SP-1182, Rev. 0, Westinghouse Hanford Company, Richland, WA.

Makenas, BJ, TL Welsh, RB Baker, EW Hoppe, AJ Schmidt, J Abrefah, JM Tingey, PR Bredt, and GR Golcar. 1997. Analysis of Sludge from Hanford K East Basin Canisters. HNF-SP-1201, DE\&S Hanford, Inc., Richland, WA.

Makenas, BJ, TL Welsh, RB Baker, GR Golcar, PR Bredt, AJ Schmidt, and JM Tingey. 1998. Analysis of Sludge from Hanford K West Basin Canisters. HNF-1728, Rev. 0, Fluor Daniel Hanford, Richland, WA.

Ondrejcin, RS. 1966. "Thermal Decomposition of Uranyl Nitrate Hexahydrate," Journal of Chemical and Engineering Data 11(1):130-133.

Perry, RH and D Green. 1984. pp 3-101 to 3-103 of Perry's Chemical Engineers' Handbook, McGrawHill Book Company, New York, NY.

Plys, MG and AJ Schmidt. 2006. Supporting Basis for SNF Project Sludge Technical Data Book. SNF-7765, Rev. 3b, Fluor Hanford, Inc., Richland, WA.

Schmidt, AJ and CH Delegard. 2003. Updated Volumetric Expansion Factors for K Basin Sludge During Storage. PNNL-14228, Pacific Northwest National Laboratory, Richland, WA. 
Shoesmith, DW. 2000. "Fuel Corrosion Processes under Waste Disposal Conditions," Journal of Nuclear Materials 282:1-31.

Shoesmith, DW and S Sunder. 1991. An Electrochemistry-Based Model for the Dissolution of $\mathrm{UO}_{2}$. AECL-10488, Whiteshell Laboratories, Pinawa, Manitoba, Canada.

Sowder, AG, SB Clark, and RA Fjeld. 1999. "The Transformation of Uranyl Oxide Hydrates: The Effect of Dehydration on Synthetic Metaschoepite and Its Alteration to Becquerelite," Environmental Science and Technology 33:3552-3557.

Thamer, BJ, RM Bidwell, HM Busey, RA Clark, SH Cox, LA Geoffrion, RP Hammond, GE Meadows, BJ Melton, RH Perkins, JR Phillips, MG Redman, JD Rogers, A Sesonske, LR Sitney, EO Swickard, WR Wykoff, and JB Zorn. 1956. The Properties of Phosphoric Acid Solutions of Uranium as Fuels for Homogeneous Reactors. LA-2043, Los Alamos Scientific Laboratory, Los Alamos, NM (http://libwww.lanl.gov/cgi-bin/getfile?00320782.pdf).

Wagman, DD, WH Evans, VB Parker, RH Schumm, I Halow, SM Bailey, KL Churney, and RL Nuttall. 1982. "The NBS Tables of Chemical Thermodynamic Properties - Selected Values for Inorganic and C1 and C2 Organic Substances in SI Units," Journal of Physical and Chemical Reference Data 11 (Supplement 2).

Weigel, F. 1986. Page 267 in "Uranium," Chapter 5 in The Chemistry of the Actinide Elements, $2^{\text {nd }}$ edition, JJ Katz, GT Seaborg, and LR Morss, editors, Chapman and Hall, New York, NY. 


\section{Appendix A}

\section{Preparation and Properties of Uraninite Received from Materials Sciences Corporation}





\section{Appendix A}

\section{Preparation and Properties of Uraninite Received from Materials Sciences Corporation}

$9 / 27 / 07$

\section{BATTELLE PURCHASE ORDER NO. 43318 - INFORMATION REQUESTED IN SCOPE OF WORK}

Information requests in italics.

1. Composition or analysis certification of the starting high purity uranium metal (e.g., chemical impurities)

$\begin{array}{cc}\text { Element } & \mu \mathrm{g} / \mathrm{g} \\ \mathrm{Mg} & <15 \\ \mathrm{Al} & <5 \\ \mathrm{Si} & <25 \\ \mathrm{Ca} & <15 \\ \mathrm{Ti} & \mathrm{ND} \\ \mathrm{Cr} & \mathrm{ND} \\ \mathrm{Mn} & <10 \\ \mathrm{Fe} & <50 \\ \mathrm{Ni} & <10 \\ \mathrm{Cu} & <5 \\ \mathrm{Zr} & \mathrm{ND} \\ \mathrm{Nb} & \mathrm{ND} \\ \mathrm{Mo} & \mathrm{ND} \\ \mathrm{V} & <2 \\ \text { Carbon }(\mu \mathrm{g} / \mathrm{g}) & 365+/-30\end{array}$

2. Available information on the source/origin of the uranium metal.

The source of the uranium is a Starmet derby. Starmet is a commercial supplier of depleted uranium metal that has since gone out of business. A derby is the metal form produced from the reduction of $U_{4}$.

3. Isotopic composition of the starting uranium metal.

$\mathrm{U}-235 \% 0.19$

U-238\% 99.81 
4. Mass of uranium, as element, being delivered in each shipment.

Using the formula weight of $\mathrm{UO}_{2.08}$

First shipment of $1.45 \mathrm{lbs}$. Uranium is $1.27 \mathrm{lbs}$.

Second shipment of $22 \mathrm{lbs}$. Uranium is $19 \mathrm{lbs}$.

5. Identification of the cutting oil/lubricant used to size-reduce the uranium metal stock for feed to the water reaction.

Semi-synthetic, from Process Fluids called P4700-MS.

6. Thickness/size of uranium shavings/chips prior to corrosion.

Average 0.045 inches for thickness, size varies.

7. Description of the cutting oil used, brief description of the cleaning procedure to remove cutting oil, and listing of chemicals/product used for the cleaning.

250 gallons of fresh water rinse. The coolant is water soluble.

8. Temperature range used to corrode the metal to generate the uranium oxide.

Range 60.0 - $66.3 \mathrm{deg}$ C, average temp. 61.9 deg C. $^{(a)}$

9. Water quality and $\mathrm{pH}$ used in the corrosion (target $\mathrm{pH}=7 \pm 3$ ).

Water quality 18.2 ohms; $\mathrm{pH}$ range $5.91-8.23$, average $\mathrm{pH} 6.85$.
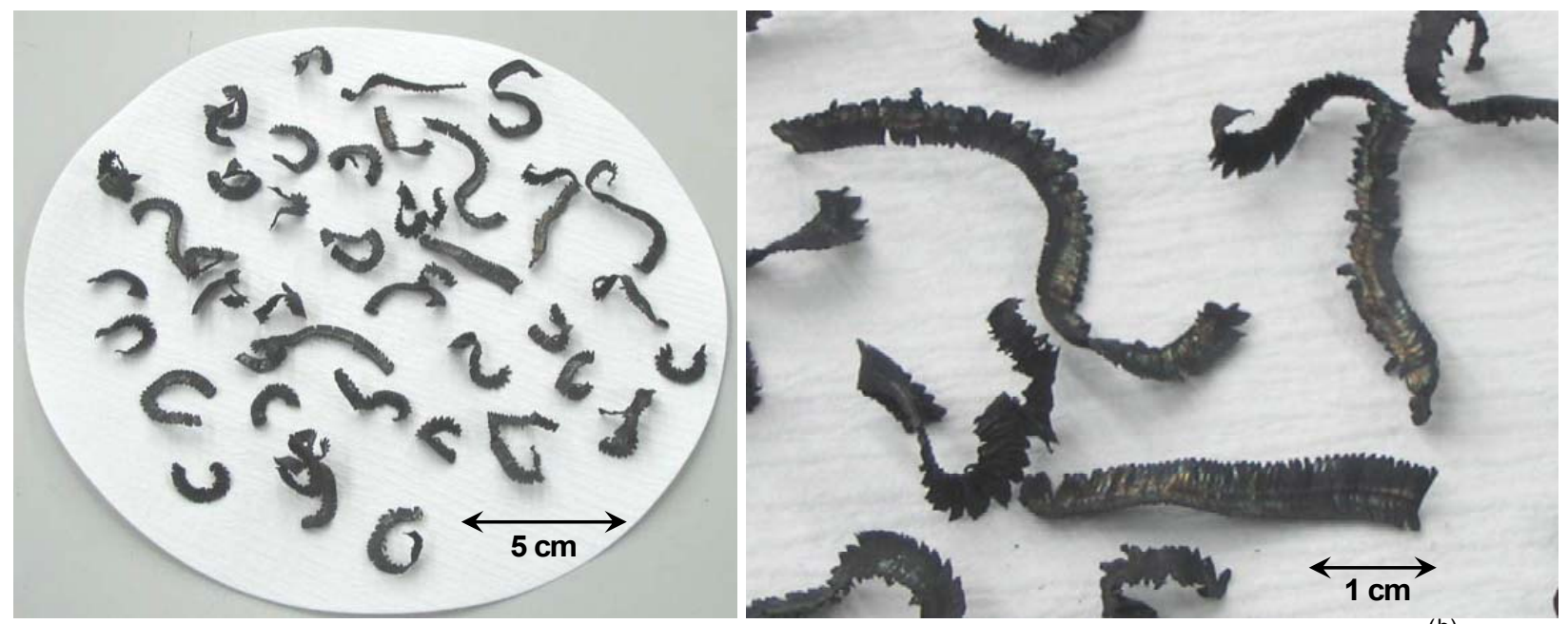

Photographs of Representative Uranium Metal Turnings Used to Generate Oxide ${ }^{(b)}$

(a) A stainless-steel lined thermostatted water bath, with insulation cover, was used.

(b) Photographs were provided by the vendor. Scale markings estimated based on 20.5-cm filter paper diameter for turnings shown in left image. 